\title{
Digital Workers of the World Unite! A Framework for Critically Theorising and Analysing Digital Labour
}

\author{
Christian Fuchs* and Marisol Sandoval ${ }^{\dagger}$ \\ "University of Westminster, christian.fuchs@uti.at \\ ${ }^{\dagger}$ City University London, marisol.sandoval.1@city.ac.uk
}

\begin{abstract}
The overall task of this paper is to elaborate a typology of the forms of labour that are needed for the production, circulation, and use of digital media. First, we engage with the question what labour is, how it differs from work, which basic dimensions it has and how these dimensions can be used for defining digital labour. Second, we introduce the theoretical notion of the mode of production as analytical tool for conceptualizing digital labour. Modes of production are dialectical units of relations of production and productive forces. Relations of production are the basic social relations that shape the economy. Productive forces are a combination of labour power, objects and instruments of work in a work process, in which new products are created. Third, we have a deeper look at dimensions of the work process and the conditions under which it takes place. We present a typology that identifies dimensions of working conditions. It is a general typology that can be used for the analysis of any production process. Fourth, we apply the typology of working conditions to the realm of digital labour and identify different forms of digital labour and the basic conditions, under which they take place. Finally, we discuss political implications of our analysis and what can be done to overcome bad working conditions that digital workers are facing today.
\end{abstract}

Keywords: critical theory, critical political economy of communication and the media, social theory, digital labour, digital work, digital media, philosophy

Muhanga is an enslaved miner in Kivu (Democratic Republic of Congo). He extracts cassiterite, a mineral that is needed for the manufacturing of laptops and mobile phones: "As you crawl through the tiny hole, using your arms and fingers to scratch, there's not enough space to dig properly and you get badly grazed all over. And then, when you do finally come back out with the cassiterite, the soldiers are waiting to grab it at gunpoint. Which means you have nothing to buy food with. So we're always hungry" (Finnwatch 2007, 20).

The Chinese engineer Lu assembles mobile phones at Foxconn Shenzhen. He reports about overwork and exhaustion: "We produced the first generation iPad. We were busy throughout a 6-month period and had to work on Sundays. We only had a rest day every 13 days. And there was no overtime premium for weekends. Working for 12 hours a day really made me exhausted" (SACOM 2010, 7; for an analysis of Foxconn see also Sandoval 2013).

In Silicon Valley, the Cambodian ICT (information and communications technology) assembler Bopha has been exposed to toxic substances. He highlights: "I talked to my coworkers who felt the same way [that I did] but they never brought it up, out of fear of losing their job" (Pellow and Park 2002, 139).

Mohan, a project manager in the Indian software industry who is in his mid-30s, explains, "Work takes a priority. [...] The area occupied by family and others keeps reducing" (D'Mello and Sahay 2007, 179). Bob, a software engineer at Google explains that, "because of the large amounts of benefits (such as free foods) there seems to be an unsaid rule that employees are expected to work longer hours. Many people work more than 8 hours a day and then will be on email or work for a couple hours at home, at night as well (or on the weekends). It may be hard to perform extremely well with a good work/life balance. Advice to Senior Management-Give engineers more freedom to use $20 \%$ time to work on cool projects without the stress of having to do $120 \%$ work" (data source: www.glassdoor.com). 
Ann, a web designer, writer, and illustrator, offers her services on the freelance market platform People Per Hour that mediates the creation and purchase of products and services that are not remunerated by worked hours, but by a fixed product price. She describes her work:

\begin{abstract}
My design styles are as broad as my client base, from typical hard hitting, sound, clear, and concise business branding, to more stylised and fluid hand drawn or illustrated work. I relish working to a deadline, and although I often work to very specific criteria, some clients are looking for a moment of inspiration, and that's where I excel. I'm always ready for a challenge, and providing the brief is concise and well conceived. I can produce work to a very tight schedule. If you are online, you will see amendments almost immediately! (data source: peopleperhour.com).
\end{abstract}

The working lives of Muhanga, Lu, Bopha, Mohan, Bob, and Ann seem completely different. Muhanga extracts minerals from nature. Lu and Bopha are industrial workers. Mohan, Bob and Ann are information workers creating either software or designs. They work under different conditions, such as slavery, wage labour, or freelancing. Yet they have in common that their labour is in different ways related to the production and use of digital technologies and that ICT companies profit from it. In this paper we discuss the commonalities and differences of the working lives of workers like these by identifying different dimensions of digital labour.

Section 1 introduces a cultural-materialist perspective on theorising digital labour. Section 2 discusses the relevance of Marx's concept of the mode of production for the analysis of digital labour. Section 3 introduces a typology of the dimensions of working conditions. Section 4 based on the preceding sections presents a digital labour analysis toolbox. Finally, we draw some conclusions in section 5 .

\title{
1. (Digital) Work and Labour: A Cultural-Materialist Perspective
}

The digital labour debate has in a first phase focused mainly on understanding the value creation mechanisms on corporate social media such as Facebook, YouTube, and Twitter. Authors have for example discussed the usefulness of Karl Marx's labour theory of value (Fuchs 2010, Arvidsson and Colleoni 2012, Fuchs 2012b, Scholz 2013), how the notion of alienation shall be used in the context of digital labour (Andrejevic 2012, Fisher 2012), or if and how Dallas Smythe's concept of audience labour can be used for understanding digital labour (for an overview discussion see Fuchs 2012a). The book Social Media: A Critical Introduction (Fuchs 2014b) provides a general introduction to many of these issues. The general task has been to understand and conceptualise a situation in which users under realtime and far-reaching conditions of commercial surveillance create a data commodity that is sold to advertising clients. This involved a discussion of the question of who exactly creates the value that manifests itself in social media corporations' profits. But going beyond these initial debates, studying digital labour requires paying attention to digital labour in all its forms.

In approaching a definition of digital labour one can learn from debates on how to define cultural and communication labour.

\subsection{Defining Cultural Labour}

There exists a latent debate between Vincent Mosco and David Hesmondhalgh about how to define cultural and communication work and where to draw the boundaries. According to Hesmondhalgh cultural industries "deal primarily with the industrial production and circulation of texts" (Hesmondhalgh 2013, 16). Thus cultural industries include broadcasting, film, music, print and electronic publishing, video and computer games, advertising, marketing and public relations, and web design. Cultural labour is therefore according to this understanding all labour conducted in these industries. Cultural labour deals "primarily with the industrial production and circulation of texts" (Hesmondhalgh 2013, 17). Following this definition Hesmondhalgh describes cultural work as "the work of symbol creators" (Hesmondhalgh 2013, 20). 
Vincent Mosco and Catherine McKercher argue for a much broader definition of communication work, including "anyone in the chain of producing and distributing knowledge products" (Mosco and McKercher 2009, 25). In the case of the book industry, this definition includes not only writers but, equally, librarians and also printers.

Hesmondhalgh's definition of cultural industries and cultural work focuses on content production. Such a definition tends to exclude digital media, ICT hardware, software, and Internet phenomena such as social media and search engines. It thereby makes the judgment that content industries are more important than digital media industries. It is idealistic in that it focuses on the production of ideas and excludes the fact that these ideas can only be communicated based on the use of physical devices, computers, software, and the Internet. For Hesmondhalgh $(2013,19)$ software engineers for example are no cultural workers because he considers their work activity as "functional" and its outcomes not as text with social meaning. Software engineering is highly creative: it is not just about creating a piece of code that serves specific purposes, but also about writing the code by devising algorithms, which poses logical challenges for the engineers. Robert L. Glass (2006) argues that software engineering is a complex form of problem solving that requires a high level of creativity that he terms software creativity. Software is semantic in multiple ways: a) when its code is executed, each line of the code is interpreted by the computer which results in specific operations; b) when using a software application online or offline our brains constantly interpret the presented information; c) software not only supports cognition, but also communication and collaboration and therefore helps humans create and reproduce social meaning. Software engineers are not just digital workers. They are also cultural workers.

Hesmondhalgh opposes Mosco's and McKercher's broad definition of cultural work because "such a broad conception risks eliminating the specific importance of culture, of mediated communication, and of the content of communication products" (Hesmondhalgh and Baker 2011, 60). Our view is that there are many advantages of a broad definition as:

1. it avoids "cultural idealism" (Williams 1977, 19) that ignores the materiality of culture,

2. it can take into account the connectedness of technology and content, and

3. it recognizes the importance of the global division of labour, the exploitation of labour in developing countries, slavery and other bloody forms of labour and thereby avoids the Western-centric parochialism of cultural idealism.

Probably most importantly, a broad conception of cultural work can inform political solidarity: "A more heterogeneous vision of the knowledge-work category points to another type of politics, one predicated on questions about whether knowledge workers can unite across occupational or national boundaries, whether they can maintain their new-found solidarity, and what they should do with it" (Mosco and McKercher 2009, 26).

Likewise, Eli Noam opposes the separation of hardware and content producers and argues for a broad definition of the information industry: "Are the physical components of media part of the information sector? Yes. Without transmitters and receivers a radio station is an abstraction. Without PCs, routers, and servers there is no Internet" (Noam 2009, 46). Noam argues for a materialist unity of content and hardware producers in the category of the information industry.

While some definitions of creative work and creative industries are input- and occupationfocused (Caves 2000, Cunningham 2005, Hartley 2005), the broad notion of cultural work we are proposing focuses on industry and output. Input- and output-oriented definitions of cultural work/industries reflect a distinction that already Fritz Machlup (1962) and Daniel Bell (1974) used in their classical studies of the information economy: the one between occupational and industry definitions of knowledge work. Our approach differs both from inputoriented definitions and narrow output-oriented definitions.

We argue that cultural workers should be seen as what Marx termed Gesamtarbeiter. Marx describes this figure of the collective worker (Gesamtarbeiter) in the Grundrisse where he discusses labour as communal or combined labour (Marx 1857/1858, 470). This idea was also taken up in Capital, Volume 1, where he defines the collective worker as "a collective 
labourer, i.e. a combination of workers" (Marx 1867, 644), and argues that labour is productive if it is part of the combined labour force: "In order to work productively, it is no longer necessary for the individual himself to put his hand to the object; it is sufficient for him to be an organ of the collective labourer, and to perform any one of its subordinate functions" (ibid.). The collective worker is an "aggregate worker" whose "combined activity results materially in an aggregate product" (ibid., 1040). The "activity of this aggregate labour-power" is "the immediate production of surplus-value, the immediate conversion of this latter into capital" (ibid.).

The question of how to define cultural and eventually also digital labour has to do with the more general question of how to understand culture. It therefore makes sense to pay some attention to the works of one of the most profound cultural theorists: Raymond Williams.

\subsection{Cultural Materialism}

In his early works, Raymond Williams was trying to understand working-class culture in contrast to bourgeois culture, which illustrates his genuinely socialist position and interest in culture. But although Williams stresses the focus on totality, i.e. culture as "the way of life as a whole" (Williams 1958, 281) and "a general social process" (Williams 1958, 282), he in his early works tended to categorically separate culture and the economy: "even if the economic element is determining, it determines a whole way of life" (Williams 1958, 281). This notion of determination implies that the two realms of the economy and culture are connected, but that in the first instance they are also separate.

Later, in Marxism and Literature, Raymond Williams questioned Marxism's historical tendency to see culture as "dependent, secondary, 'superstructural': a realm of 'mere' ideas, beliefs, arts, customs, determined by the basic material history" (Williams 1977, 19). He discusses various concepts that Marxist theories have used for conceptualising the relationship of the economy and culture: determination, reflection, reproduction, mediation, homology. $\mathrm{He}$ argues that these concepts all assume a relationship between the economy and culture that to a varying degree is shaped by causal determination or mutual causality. But all of them would share the assumption of "the separation of 'culture' from material social life" (Williams $1977,19)$ that Williams $(1977,59)$ considers to be "idealist". In Williams view the problem with these approaches is not that they are too economistic and materialist but quite on the contrary that they are not "materialist enough" (Williams 1977, 92).

Williams $(1977,78)$ argues that Marx opposed the "separation of 'areas' of thought and activity". Production would be distinct from "consumption, distribution, and exchange" as well as from social relations (Williams 1977, 91). Productive forces would be "all and any of the means of the production and reproduction of real life", including the production of social knowledge and co-operation (Williams 1977, 91). Politics and culture would be realms of material production: ruling classes would produce castles, palaces, churches, prisons, workhouses, schools, weapons, a controlled press, etc. (Williams 1977, 93). Therefore Williams highlights the "material character of the production of a social and political order" and describes the concept of the superstructure an evasion (Williams 1977, 93). Here, Williams reflects Gramsci's insight that "popular beliefs" and "similar ideas are themselves material forces" (Gramsci 1988, 215).

Raymond Williams $(1977,111)$ formulates as an important postulate of Cultural Materialism that "[c]ultural work and activity are not [...] a superstructure" because people would use physical resources for leisure, entertainment, and art. Combining Williams' assumptions that cultural work is material and economic and that the physical and ideational activities underlying the existence of culture are interconnected means that culture is a totality that connects all physical and ideational production processes that are connected and required for the existence of culture. Put in simpler terms this means that for Williams the piano maker, the composer, and the piano player all are cultural workers.

Williams $(1977,139)$ concludes that Cultural Materialism needs to see "the complex unity of the elements" required for the existence of culture: ideas, institutions, formations, distribution, technology, audiences, forms of communication and interpretation, worldviews (138f). A 
sign system would involve the social relations that produce it, the institutions in which it is formed and its role as a cultural technology (Williams 1977, 140). In order to avoid the "real danger of separating human thought, imagination and concepts from 'men's material lifeprocess'" (Williams 1989, 203), one needs to focus on the "totality of human activity" (Williams 1989,203$)$ when discussing culture: We "have to emphasise cultural practice as from the beginning social and material" (Williams 1989, 206). The "productive forces of "mental labour' have, in themselves, an inescapable material and thus social history" (William 1989, 211). Marx expressed the basic assumption of Cultural Materialism well by stressing that the "production of ideas, of conceptions, of consciousness, is at first directly interwoven with the material activity and the material intercourse of men" (Marx and Engels 1845/46, 42). The production of ideas is therefore the "language of real life" (Marx and Engels 1845/46, 42). "Men are the producers of their conceptions, ideas, etc., that is, real, active men, as they are conditioned by a definite development of their productive forces and of the intercourse corresponding to these, up to its furthest forms" (Marx and Engels 1845/46, 42). Thinking and communicating for Marx are processes of production that are embedded into humans' everyday life and work. Human beings produce their own capacities and realities of thinking and communication in work and social relations.

In his later works, Williams stressed that it is particularly the emergence of an information economy in which information, communication, and audiences are sold as commodities that requires rethinking the separation of the economy and culture and to see culture as material. "[l]nformation processes [...] have become a qualitative part of economic organization" (Williams 1981, 231). "Thus a major part of the whole modern labour process must be defined in terms which are not easily theoretically separable from the traditional 'cultural' activities. [...] so many more workers are involved in the direct operations and activations of these systems that there are quite new social and social-class complexities" (Williams 1981, 232).

As information is an important aspect of economic production in information societies, the culture concept cannot be confined to popular culture, entertainment, works of arts, and the production of meaning through the consumption of goods, but needs to be extended to the realm of economic production and value creation. Cultural labour is a crucial concept in this context.

\subsection{A Materialist Notion of Cultural Labour}

Inspired by Raymond Williams' cultural materialism, it is feasible to argue for a broad understanding of cultural and digital labour that transcends the cultural idealism of the early digital labour debate and some positions within the cultural industries school. On the one hand Williams refutes the separation of culture and the economy as well as base and superstructure. On the other hand he maintains that culture, as a signifying system, is a distinct system of society. How can we make sense of these claims that at first sight seem to be mutually exclusive? If one thinks dialectically, then a concept of culture as material and necessarily economic and at the same time distinct from the economy is feasible: culture and politics are dialectical sublations (Aufhebung) of the economy. In Hegelian philosophy sublation means that a system or phenomenon is preserved, eliminated, and lifted up. Culture is not the same as the economy, it is more than the sum of various acts of labour, it has emergent qualitiesit communicates meanings in society-that cannot be found in the economy alone. But at the same time, the economy is preserved in culture: culture is not independent from labour, production and physicality, but requires and incorporates all of them.

Wolfgang Hofkirchner has introduced stage models as a way for philosophically conceptualizing the logic connections between different levels of organization. In a stage model, "one step taken by a system in question-that produces a layer-depends on the stage taken prior to that but cannot be reversed! [...] layers-that are produced by steps-build upon layers below them but cannot be reduced to them!" (Hofkirchner 2013, 123f). Emergence is the foundational principle of a stage model (Hofkirchner 2013, 115): a specific level of organization of matter has emergent qualities so that the systems organized on this level are more than the sum of their parts, to which they cannot be reduced. An organization level has new 
qualities that are grounded in the underlying systems and levels that are preserved on the upper level and through synergies produce new qualities of the upper level. In the language of dialectical philosophy this means that the emergent quality of an organization level is a sublation (Aufhebung) of the underlying level.

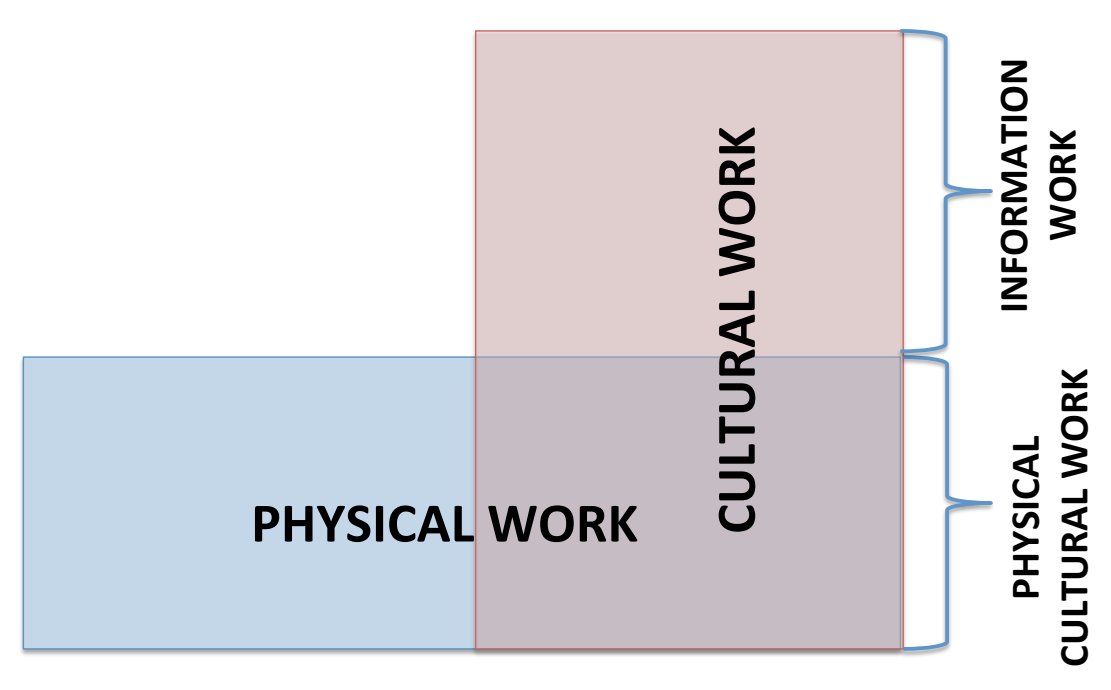

Figure 1: A stage model of cultural work

Using a stage model allows us to identify and relate different levels of cultural and digital work (see figure 1). Cultural work is a term that encompasses organisational levels of work that are at the same time distinct and dialectically connected: cultural work has an emergent quality, namely information work that creates content, that is based on and grounded in physical cultural work, which creates information technologies through agricultural and industrial work processes. Physical work takes place inside and outside of culture: it creates information technologies and its components (cultural physical work) as well as other products (non-cultural physical work) that do not primarily have symbolic functions in society (such as cars, tooth brushes or cups). Cars, toothbrushes, or cups do not primarily have the role of informing others or communicating with others, but rather help humans achieve the tasks of transport, cleanliness and nutrition. Culture and information work however feedback on these products and create symbolic meanings used by companies for marketing them. Cultural work is a unity of physical cultural work and information work that interact with each other, are connected and at the same time distinct.

The production of meaning, social norms, morals, and the communication of meanings, norms, and morals are work processes: they create cultural use-values. Culture requires on the one hand human creativity for creating cultural content and on the other hand specific forms and media for storage and communication. Work that creates information and communication through language is specific for work conducted in the cultural system: informational and communication work. For having social effects in society, information, and communication are organized (stored, processed, transported, analysed, transformed, created) with the help of information and communication technologies, such as computers, TV, radio, newspapers, books, recorded films, recorded music, language, etc. These technologies are produced by physical cultural work. Culture encompasses a) physical and informational work that create cultural technologies (information and communication technologies) and b) information work that creates information and communication.

These two types of work act together in order to produce and reproduce culture. Meanings and judgements are emergent qualities of culture that are created by informational work, they take on relative autonomy that has effects inside but also outside the economic system. This means that specific forms of work create culture, but culture cannot be reduced to the economy-it has emergent qualities. 
Following Williams, communication is the "passing of ideas, information, and attitudes from person to person", whereas communications means the "institutions and forms in which ideas, information, and attitudes are transmitted and received" (Williams 1962, 9). Information and communication are meaning-making activities created by informational work. Physical cultural work creates communications as institutions and forms that organize the creation and passing of information in social processes.

Marx identified two forms of information work: The first results in cultural goods that "exist separately from the producer, i.e. they can circulate in the interval between production and consumption as commodities, e.g. books, paintings and all products of art as distinct from the artistic achievement of the practising artist". In the second, "the product is not separable from the act of producing" (Marx 1867, 1047f). The first requires a form, institution or technology that stores and transports information, as in the case of computer-mediated communication, the second uses language as main medium (e.g. theatre). The first requires physical cultural work for organizing storage, organization, and transport of information; the second is possible based only on information work.

Given the notion of cultural labour and a cultural-materialist framework inspired by Raymond Williams, we can next ask the question what is specific about the digital mode of cultural labour.

\subsection{Digital Work and Digital Labour}

The realm of digital media is a specific subsystem of the cultural industries and of cultural labour. Digital labour is a specific form of cultural labour that has to do with the production and productive consumption of digital media. There are other forms of cultural labour that are non-digital. Think for example of a classical music or rock concert. But these forms of live entertainment that are specific types of cultural labour also do not exist independently from the digital realm: Artists publish their recordings in digital format on iTunes, Spotify, and similar online platforms. Fans bring their mobile phones for taking pictures and recording concert excerpts that they share on social media platforms. There is little cultural labour that is fully independent from the digital realm today. The notion of digital work and digital labour wants to signify those forms of cultural labour that contribute to the existence of digital technologies and digital content. It is a specific form of cultural labour. Figure 2 applies the stage model of cultural work (see figure 1 above) to digital work.

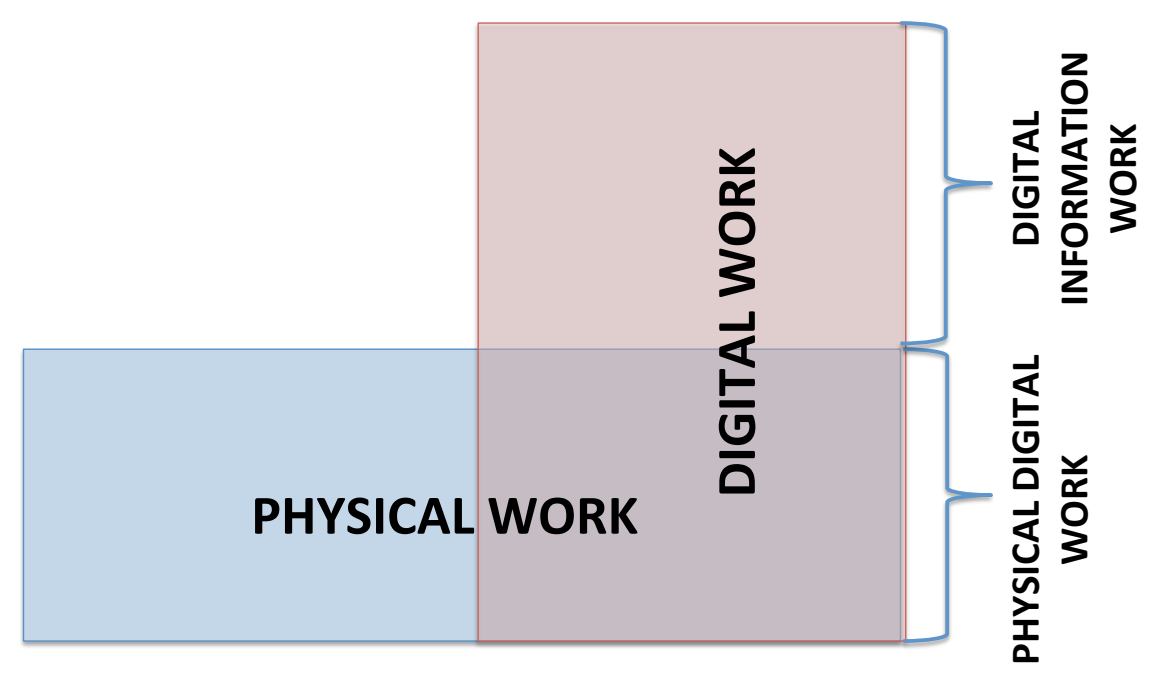

Figure 2: A stage model of digital work

If culture were merely symbolic, mind, spirit, "immaterial", superstructural, informational, a world of ideas, then digital labour as expression of culture clearly would exclude the concrete 
works of mining and hardware assemblage that are required for producing digital media. Williams' Cultural Materialism, contrary to the position of Cultural Idealism, makes it possible to argue that digital labour includes both the creation of physical products and information that are required for the production and usage of digital technologies. Some digital workers create hardware, others hardware components, minerals, software or content that are all objectified in or the outcome of the application of digital technologies. Some workers, e.g. miners, not just contribute to the emergence of digital media, but to different products. If one knows the mines' sales, then it is possible to determine to which extent the performed labour is digital or other labour.

In order to illustrate this point that culture is material, we now want return in greater detail to a passage where Marx reflects about the work of making and playing the piano. Marx wrote:

\begin{abstract}
Productive labour is only that which produces capital. Is it not crazy, asks e.g. (or at least something similar) $\mathrm{Mr}$ Senior, that the piano maker is a productive worker, but not the piano player, although obviously the piano would be absurd without the piano player? But this is exactly the case. The piano maker reproduces capital; the pianist only exchanges his labour for revenue. But doesn't the pianist produce music and satisfy our musical ear, does he not even to a certain extent produce the latter? He does indeed: his labour produces something; but that does not make it productive labour in the economic sense; no more than the labour of the madman who produces delusions is productive. Labour becomes productive only by producing its own opposite (Marx 1857/58, 305).
\end{abstract}

Williams remarks that today, other than in Marx's time, "the production of music (and not just its instruments) is an important branch of capitalist production" (Williams 1977, 93).

If the economy and culture are two separate realms, then building the piano is work and part of the economy and playing it is not work, but culture. Marx leaves however no doubt that playing the piano produces a use-value that satisfies human ears and is therefore a form of work. As a consequence, the production of music must just like the production of the piano be an economic activity. Williams $(1977,94)$ stresses that cultural materialism means to see the material character of art, ideas, aesthetics and ideology and that when considering piano making and piano playing it is important to discover and describe "relations between all these practices" and to not assume "that only some of them are material".

Apart from the piano maker and the piano player there is also the composer of music. All three forms of work are needed and necessarily related in order to guarantee the existence of piano music. Fixing one of these three productive activities categorically as culture and excluding the others from it limits the concept of culture and does not see that one cannot exist without the other. Along with this separation come political assessments of the separated entities. A frequent procedure is to include the work of the composer and player and to exclude the work of the piano maker. Cultural elitists then argue that only the composer and player are truly creative, whereas vulgar materialists hold that only the piano maker can be a productive worker because he works with his hands and produces an artefact. Both judgments are isolationist and politically problematic.

Taking the example of piano music and transferring it to digital media, we find correspondences: Just like we find piano makers, music composers and piano players in the music industry, we find labour involved in hardware production (makers), content and software production (composers) and productive users (prosumers, players, play labour) in the world of digital labour. In the realm of digital labour, we have to emphasize that practices are "from the beginning social and material" (Williams 1989, 206).

There is a difference if piano makers, players and music composers do so just as a hobby or for creating commodities that are sold on the market. This distinction can be explored based on Marx's distinction between work (Werktätigkeit) and labour (Arbeit): Brigitte Weingart (1997) describes the origins of the terms work in English and Arbeit and Werk in German: In German, the word Arbeit comes from the Germanic term arba, which meant slave. The English term work comes from the Middle English term weorc. It was a fusion of the Old English terms wyrcan (creating) and wircan (to affect something). So to work means 
to create something that brings about some changes in society. Weorc is related to the German terms Werk and werken. Both work in English and Werk in German were derived from the Indo-European term uerg (doing, acting). Werken in German is a term still used today for creating something. Its origins are quite opposed to the origins of the term Arbeit. The result of the process of werken is called Werk. Both werken and Werk have the connotative meaning of being creative. Both terms have an inherent connotation of artistic creation. Arendt (1958, 80f) confirms the etymological distinction between ergazesthai (Greek)/facere, fabricari (Latin)/work (English)/werken (German)/ouvrer (French) and ponein (Greek)/laborare (Latin)/labour (English)/arbeiten (German)/travailler (French).

Raymond Williams $(1983,176-179)$ argues that the word "labour" comes from the French word labor and the Latin term laborem and appeared in the English language first around 1300. It was associated with hard work, pain and trouble. In the 18th century, it would have attained the meaning of work under capitalist conditions that stands in a class relationship with capital. The term "work" comes from the Old English word weorc and is the "most general word for doing something" (ibid., 334). In capitalism the term on the one hand has, according to Williams (ibid., 334-337), acquired the same meaning as labour-a paid job-but would have in contrast also kept its original broader meaning. In order to be able to differentiate the dual historical and essential character of work, it is feasible to make a semantic differentiation between labour and work.

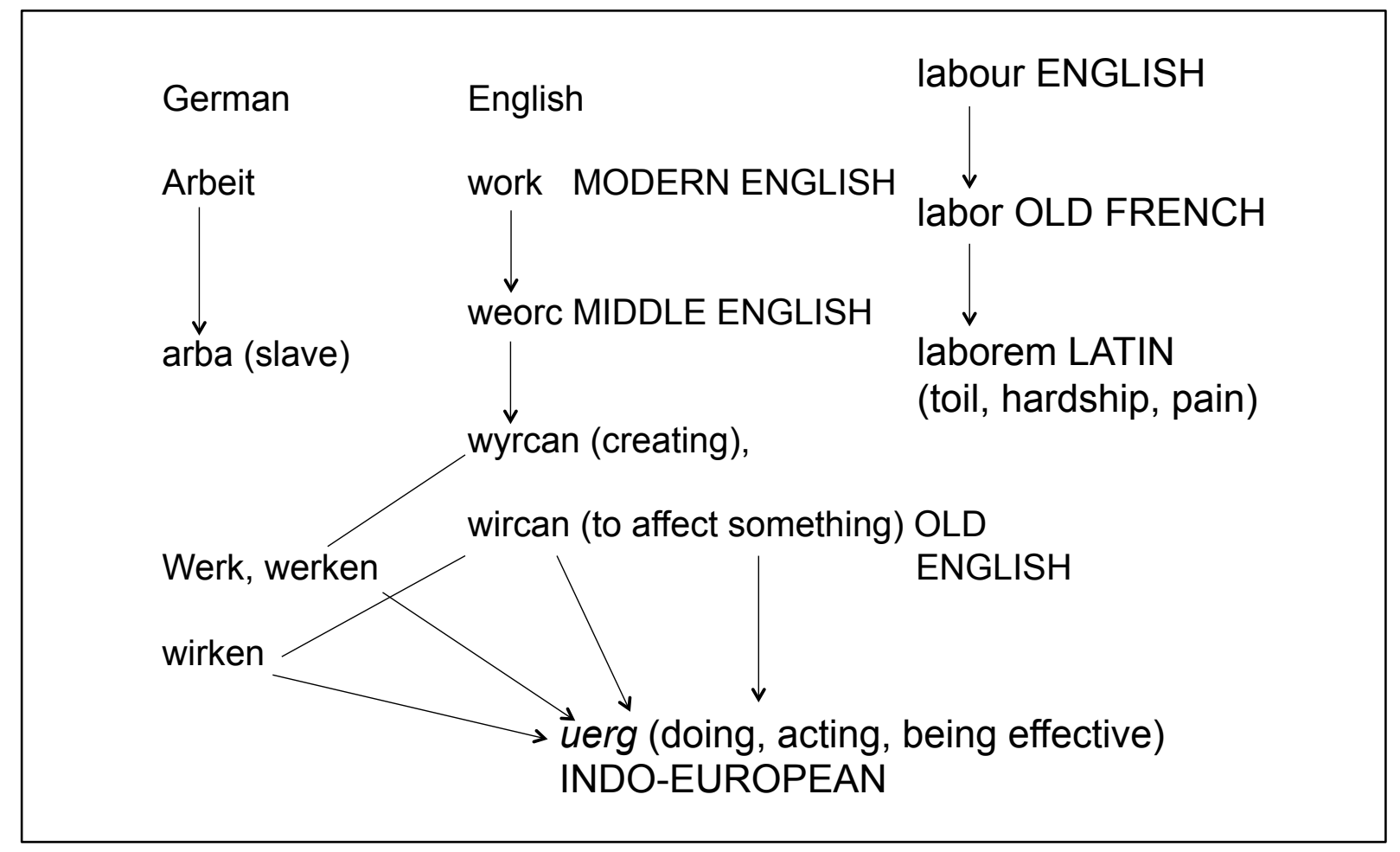

Figure 3: The etymology of the terms work, labour and Arbeit

The meaning and usage of words develops historically and may reflect the structures and changes of society, culture and the economy. Given that we find an etymological distinction between the general aspects of productive human activities and the specific characteristics that reflect the realities of class societies, it makes sense to categorically distinguish between the anthropological dimension of human creative and productive activities that result in usevalues that satisfy human needs and the historical dimension that describes how these activities are embedded into class relations (Fuchs 2014a). A model of the general work process is visualized in figure 4 . 


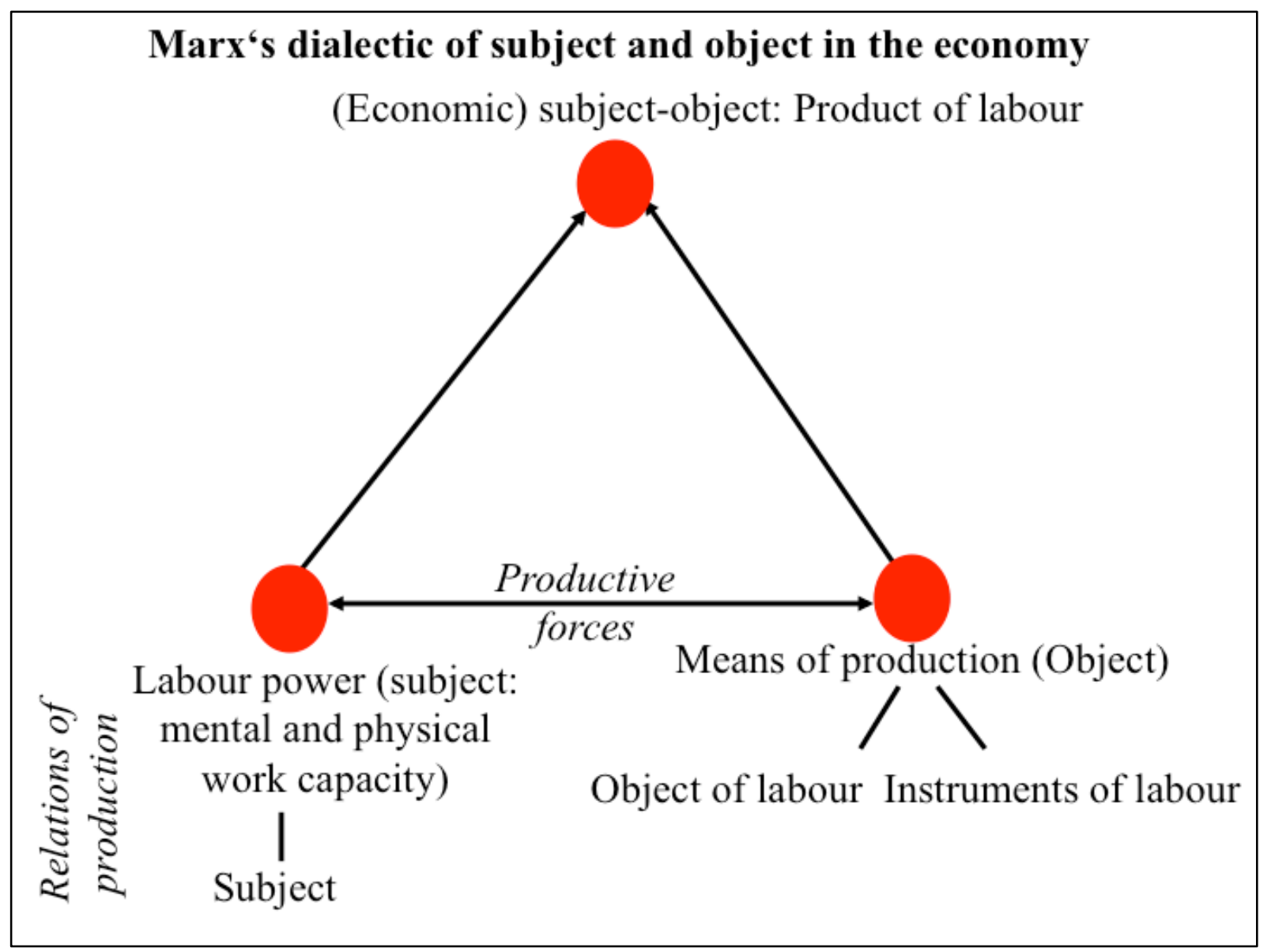

Figure 4: The general work process

Human subjects have labour power. Their labour in the work process interacts with the means of production (object). The means of production consist of the object of labour (resources, raw materials) and the instruments of labour (technology). In the work process, humans transform an object (nature, culture) by making use of their labour power with the help of instruments of labour. The result is a product that unites the objectified labour of the subject with the objective materials s/he works on. Work becomes objectified in a product and the object is as a result transformed into a use value that serves human needs. The productive forces are a system, in which subjective productive forces (human labour power) make use of technical productive forces (part of the objective productive forces) in order to transform parts of the nature/culture so that a product emerges.

The general work process is an anthropological model of work under all historical conditions. The connection of the human subject to other subjects in figure 4 indicates that work is normally not conducted individually, but in relations with others. A society could hardly exist based on isolated people trying to sustain themselves independently. It requires economic relations in the form of co-operation and a social organization of production, distribution and consumption. This means that work takes place under specific historical social relations of production. There are different possibilities for the organization of the relations of production. In general the term labour points towards the organization of labour under class relations, i.e. power relationships that determine that any or some of the elements in the work process are not controlled by the workers themselves, but by a group of economic controllers. Labour designates specific organization forms of work, in which the human subject does not control his/her labour power (she is compelled to work for others) and/or there is a lack of control of the objects of labour and/or the instruments of labour and/or the products of labour.

Karl Marx pinpoints this lack of control by the term alienation and understands the unity of these forms of alienation as exploitation of labour: "The material on which it [labour] works is 
alien material; the instrument is likewise an alien instrument; its labour appears as a mere accessory to their substance and hence objectifies itself in things not belonging to it. Indeed, living labour itself appears as alien vis-à-vis living labour capacity, whose labour it is, whose own life's expression it is, for it has been surrendered to capital in exchange for objectified labour, for the product of labour itself. [...] labour capacity's own labour is as alien to it - and it really is, as regards its direction etc.-as are material and instrument. Which is why the product then appears to it as a combination of alien material, alien instrument and alien labour-as alien property" (Marx 1857/58, 462). Figure 5 visualizes potential dimensions of the labour process as alienated work process.

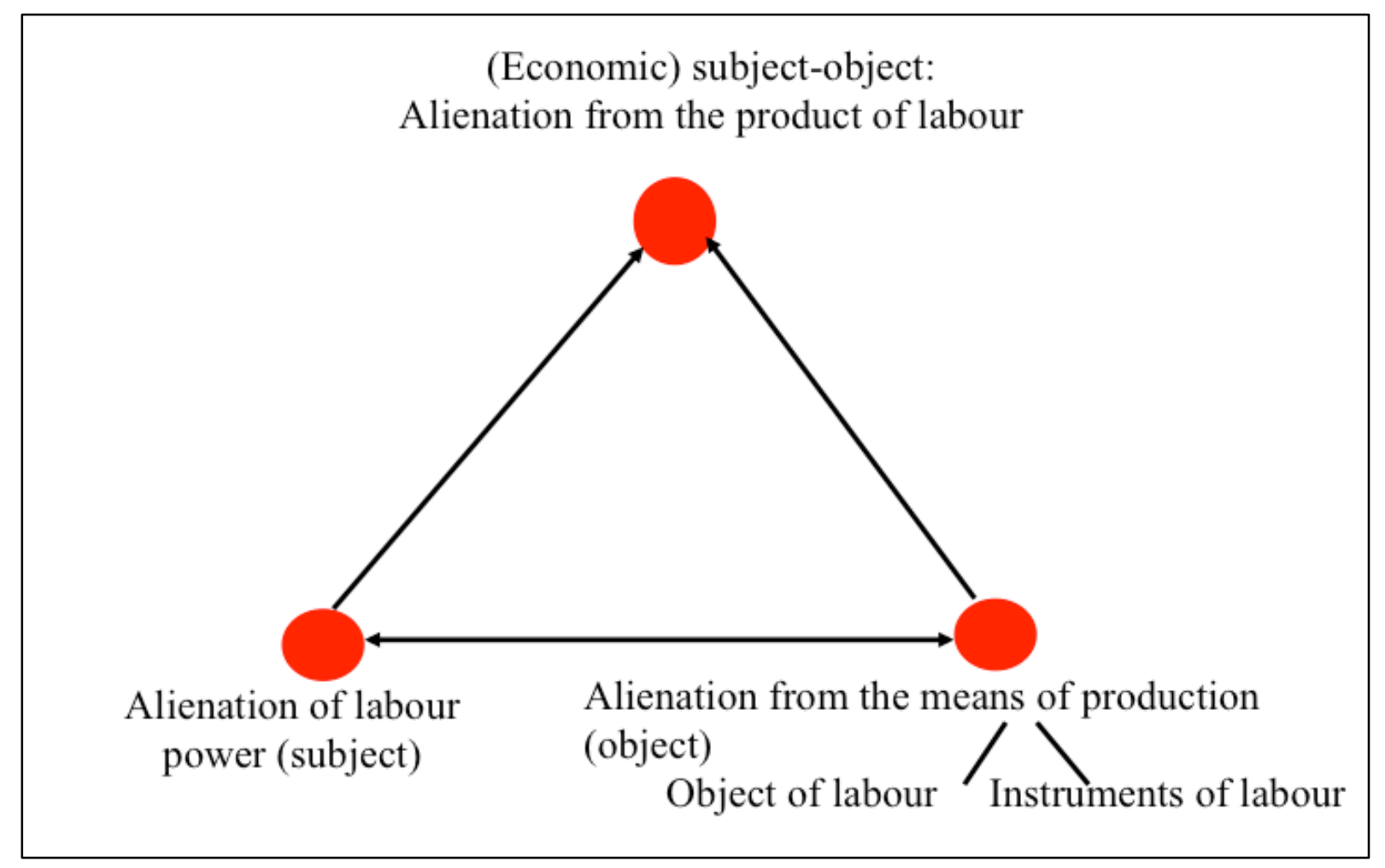

Figure 5: Labour as alienated work process

Given these preliminary assumptions about the work-labour distinction and cultural materialism, one can provide a definition of digital work and digital labour:

Digital work is a specific form of work that makes use of the body, mind or machines or a combination of all or some of these elements as an instrument of work in order to organize nature, resources extracted from nature, or culture and human experiences, in such a way that digital media are produced and used. The products of digital work are depending on the type of work: minerals, components, digital media tools or digitally mediated symbolic representations, social relations, artefacts, social systems and communities. Digital work includes all activities that create use-values that are objectified in digital media technologies, contents and products generated by applying digital media" (Fuchs 2014a, 352).

Digital labour is alienated digital work: it is alienated from itself, from the instruments and objects of labour and from the products of labour. Alienation is alienation of the subject from itself (labour-power is put to use for and is controlled by capital), alienation from the object (the objects of labour and the instruments of labour) and the subject-object (the products of labour). Digital work and digital labour are broad categories that involve all activities in the production of digital media technologies and contents. This means that in the capitalist media industry, different forms of alienation and exploitation can be encountered. Examples are slave workers in mineral extraction, Taylorist hardware assemblers, 
software engineers, professional online content creators (e.g. online journalists), call centre agents and social media prosumers" (Fuchs 2014a, 351f).

Work and labour are not isolated individual activities, but take place as part of social relations and larger modes of how the economy is organised. The concepts of digital work and digital labour need therefore to be related to a concept that can describe the organisational structure of the economy. One such concept is Marx's notion of the mode of production.

\section{Digital Labour and Modes of Production}

Michael Porter (1985) introduced the notion of the value chain that he defined as "a collection of activities that are performed to design, produce, market, deliver and support its product" (Porter 1985: 36). The term value chain has become a popular category for analysing the organisation of capital, which is indicated by the circumstance that 11682 articles indexed in the academic database Business Source Premier use the term in their abstract (accessed on May 21,2013$)$. The term has also been used in mainstream media economics for analysing the value chains of traditional media and ICTs (see Zerdick et al. 2000: 126-135). The problem of the mainstream use of the concept of the value chain is that it focuses on the stages in commodity production and tends to neglect aspects of working conditions and class relations. Also critical scholars have used the notion of the global value chain (see for example: Huws 2008, Huws and Dahlmann 2010).

An alternative concept that was introduced by critical studies is the notion of the new international division of labour (NIDL):

The development of the world economy has increasingly created conditions (forcing the development of the new international division of labour) in which the survival of more and more companies can only be assured through the relocation of production to new industrial sites, where labour-power is cheap to buy, abundant and well-disciplined; in short, through the transnational reorganization of production (Fröbel, Heinrichs and Kreye 1981, 15).

A further development is that "commodity production is being increasingly subdivided into fragments which can be assigned to whichever part of the world can provide the most profitable combination of capital and labour" (Fröbel, Heinrichs and Kreye 1981, 14). In critical media and cultural studies, Miller et al. (2004) have used this concept for explaining the international division of cultural labour (NICL). The concept of the NIDL has the advantage that it stresses the class relationship between capital and labour and how in processes of class struggle capital tries to increase profits by decreasing its overall wage costs via the global diffusion of the production process. It is also a concept that encompasses workers' struggles against the negative effects of capitalist restructuring.

The approach taken in this paper stands in the Marxist tradition that stresses class contradictions in the analysis of globalisation. It explores how the notion of the mode of production can be connected to the concept of the new international division of labour. The notion of the mode of production stresses a dialectical interconnection of on the one hand class relationships (relations of production) and on the other hand the forms of organisation of capital, labour and technology (productive forces). The class relationship is a social relationship that determines who owns private property and has the power to make others produce surplusvalue that they do not own and that is appropriated by private property owners. Class relationships involve an owning class and a non-owing class: the non-owning class is compelled to produce surplus value that is appropriated by the owning class.

The relations of production determine the property relations (who owns which share (full, some, none) of labour power, the means of production, products of labour), the mode of allocation and distribution of goods, the mode of coercion used for defending property relations and the division of labour. Class relationships are forms of organization of the relations of production, in which a dominant class controls the modes of ownership, distribution and coercion for exploiting a subordinated class. In a classless society human control ownership and distribution in common. 
Every economy produces a certain amount of goods per year. Specific resources are invested and there is a specific output. If there is no contraction of the economy due to a crisis, then a surplus product is created, i.e. an excess over the initial resources. The property relations determine who owns the economy's initial resources and surplus. Table 2 (see further below) distinguishes modes of production (patriarchy, slavery, feudalism, capitalism, communism) based on various modes of ownership, i.e. property relations.

The mode of allocation and distribution defines how products are distributed and allocated: In a communist society, each person gets whatever s/he requires to survive and satisfy human needs. In class societies, distribution is organized in the form of exchange: exchange means that one product is exchanged for another. If you have nothing to exchange because you own nothing, then you cannot get hold of other goods and services, except those that are not exchanged, but provided for free. There are different forms how exchange can be organized: general exchange, exchange for exchange-value ( $x$ commodity $A=y$ commodity $B$ ), exchange for maximum exchange-value, exchange for capital accumulation.

The mode of coercion takes on the form of physical violence (overseers, security forces, military), structural violence (markets, institutionalised wage labour contracts, legal protection of private property, etc) and cultural violence (ideologies that present the existing order as the best possible or only possible order and try to defer the causes of societal problems by scapegoating). In a free society no mode of coercion is needed.

The division of labour defines who conducts which activities in the household, the economy, politics and culture. Historically there has been a gender division of labour, a division between mental and physical work, a division into many different functions conducted by specialists and an international division of labour that is due to the globalization of production. Marx in contrast imagined a society of generalists that overcomes the divisions of labour so that society is based on well-rounded universally active humans (Marx 1867, 334-335). Marx $(1857 / 58,238)$ says that in class society "labour will create alien property and property will command alien labour". The historical alternative is a communist society and mode of production, in which class relationships are dissolved and the surplus product and private property are owned and controlled in common.

The relations of production are dialectically connected to the system of the productive forces (see figure 3 in section 1 of this paper): human subjects have labour power that in the labour process interacts with the means of production (object). The means of production consist of the object of labour (natural resources, raw materials) and the instruments of labour (technology). In the labour process, humans transform the object of labour (nature, culture) by making use of their labour power with the help of instruments of labour. The result is a product of labour, which is a Hegelian subject-object, or, as Marx says, a product, in which labour has become bound up in its object: labour is objectified in the product and the object is as a result transformed into a use value that serves human needs. The productive forces are a system, in which subjective productive forces (human labour power) make use of technical productive forces (part of the objective productive forces) in order to transform parts of the natural productive forces (which are also part of the objective productive forces) so that a labour product emerges. One goal of the development of the system of productive forces is to increase the productivity of labour, i.e. the output (amount of products) that labour generates per unit of time. Marx $(1867,431)$ spoke in this context of the development of the productive forces. Another goal of the development of the productive forces can be the enhancement of human self-development by reducing necessary labour time and hard work (toil).

In Capital, Marx (1867) makes a threefold distinction between labour-power, the object of labour and the instruments of labour: "The simple elements of the labour process are (1) purposeful activity, (2) the object on which that work is performed, and (3) the instruments of that work" (284). Marx's discussion of the production process can be presented in a systematic way by using Hegel's concept of the dialectic of subject and object. Hegel (1991) has spoken of a dialectical relation of subject and object: the existence of a producing subject is based on an external objective environment that enables and constrains (i.e. conditions) human existence. Human activities can transform the external (social, cultural, economic, politi- 
cal, natural) environment. As a result of the interaction of subject and object, new reality is created-Hegel terms the result of this interaction "subject-object". Figure 5 shows that $\mathrm{He}-$ gel's notion of subject, object, and subject-object form a dialectical triangle.

Hegel (1991) characterizes the "subjective concept" as formal notion (\$162), a finite determination of understanding a general notion (§162), "altogether concrete" (§164). He defines "the subject" as "the posited unseparatedness of the moments in their distinction" (§164). Hegel characterizes objectivity as totality (§193),"external objectivity"(§208),"external to an other" (§193), "the objective world in general" that "falls apart inwardly into [an] undetermined manifoldness" (§193), "immediate being" (§194), "indifference vis-à-vis the distinction" (§194), "realisation of purpose" (§194), "purposive activity" (§206) and "the means" (§206).The Idea is "the Subject-Object" (§162), absolute Truth (§162), the unity of the subjective and the objective (\$212), "the absolute unity of Concept and objectivity" (§213), "the Subject-Object" understood as "the unity of the ideal and the real, of the finite and the infinite, of the soul and the body" (\$214). Hegel also says that the "Idea is essentially process" (\$215). Marx applied Hegel's dialectic of subject and object on a more concrete level to the economy in order to explain how the process of economic production works as an interconnection of a subject (labour power) and an object (objects and instruments) so that a subject-object (product) emerges (see figure 6).

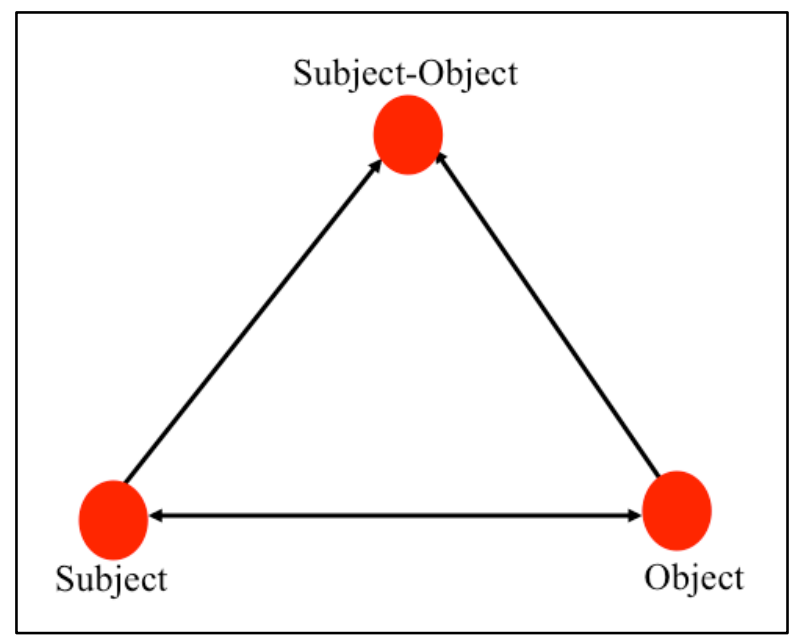

Figure 6: Hegel's dialectic of subject and object

The instruments of work can be the human brain and body, mechanical tools and complex machine systems. They also include specific organizations of space-time, i.e. locations of production that are operated at specific time periods. The most important aspect of time is the necessary work time that depends on the level of productivity. It is the work time that is needed per year for guaranteeing the survival of a society. The objects and products of work can be natural, industrial or informational resources or a combination thereof.

The productive forces are a system of production that creates use-values. There are different modes of organization of the productive forces, such as agricultural productive forces, industrial productive forces and informational productive forces. Table 1 gives an overview. 


\begin{tabular}{|l|l|l|l|}
\hline Mode & Instruments of work & Objects of work & $\begin{array}{l}\text { Products of } \\
\text { work }\end{array}$ \\
\hline $\begin{array}{l}\text { Agricultural productive } \\
\text { forces }\end{array}$ & $\begin{array}{l}\text { Body, brain, tools, } \\
\text { machines }\end{array}$ & Nature & Basic products \\
\hline $\begin{array}{l}\text { Industrial productive } \\
\text { forces }\end{array}$ & $\begin{array}{l}\text { Body, brain, tools, } \\
\text { machines }\end{array}$ & $\begin{array}{l}\text { Basic products, in- } \\
\text { dustrial products }\end{array}$ & $\begin{array}{l}\text { Industrial prod- } \\
\text { ucts }\end{array}$ \\
\hline $\begin{array}{l}\text { Informational produc- } \\
\text { tive forces }\end{array}$ & $\begin{array}{l}\text { Body, brain, tools, } \\
\text { machines }\end{array}$ & Experiences, ideas & $\begin{array}{l}\text { Informational } \\
\text { products }\end{array}$ \\
\hline
\end{tabular}

Table 1. Three Modes of Organization of the Productive Forces

Figure 7 shows dimensions of the relations of production and the productive forces.

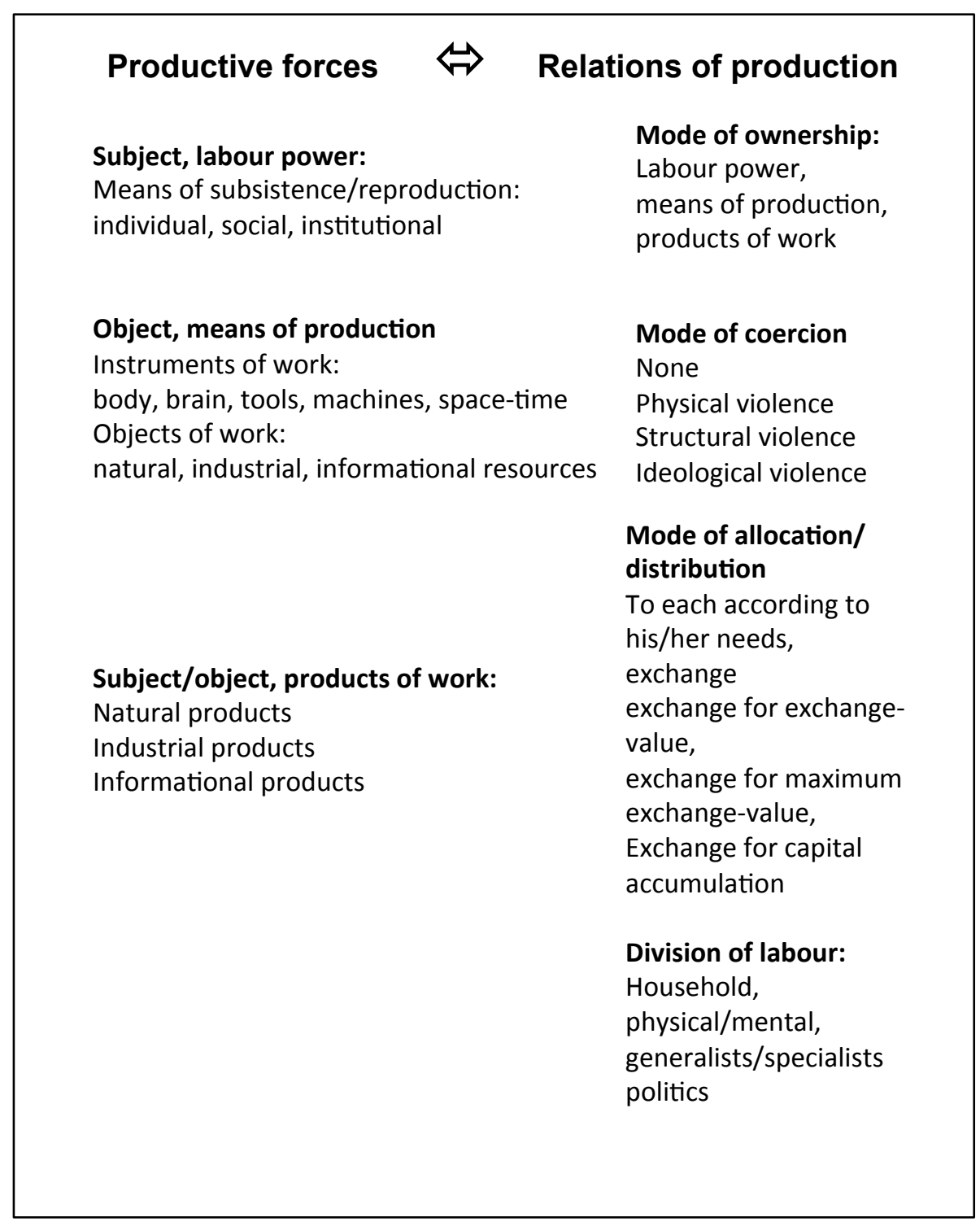

Figure 7: Dimensions of the Productive Forces and the Relations of Production 
Classical slavery, serfdom and wage labour are three important historical forms of class relations that are at the heart of specific modes of production (Engels 1884). Marx and Engels argue that private property and slavery have their origin in the family: The first historical form of private property can be found in the patriarchal family (Marx and Engels 1845/46, 52). The family is a mode of production, in which labour power is no commodity, but organised by personal and emotional relationships that result in commitment that includes family work that is unremunerated and produces affects, social relations and the reproduction of the human mind and body. It can therefore also be called reproductive work.

A wage worker's labour power has a price, its wage, whereas a slave's labour power does not have a price-it is not a commodity. However, the slave him-/herself has a price, which means that its entire human body and mind can be sold as a commodity from one slave owner to another, who then commands the entire life time of the slave (Marx, 1857/58: 288289). The slave in both ancient slavery and feudalism is treated like a thing and has the status of a thing (Marx 1857/58, 464-465).

In the Grundrisse's section "Forms which precede capitalist production" (Marx 1857/58, 471-514) as well as in the German Ideology's section "Feuerbach: Opposition of the materialist and idealist outlooks" (Marx and Engels 1845/46), Marx discusses the following modes of production:

1. The tribal community based on the patriarchal family;

2. Ancient communal property in cities (Rome, Greece);

3. Feudal production in the countryside;

4. Capitalism.

Table 2 provides a classification of modes of production based on the dominant forms of ownership (self-control, partly self-control and partly alien control, full alien control)

\begin{tabular}{|l|l|l|l|}
\hline & $\begin{array}{l}\text { Owner of labour } \\
\text { power }\end{array}$ & $\begin{array}{l}\text { Owner of the means } \\
\text { of production }\end{array}$ & $\begin{array}{l}\text { Owner of the prod- } \\
\text { ucts of work }\end{array}$ \\
\hline Patriarchy & Patriarch & Patriarch & Family \\
\hline Slavery & Slavemaster & Slavemaster & Slavemaster \\
\hline Feudalism & $\begin{array}{l}\text { Partly self-control, } \\
\text { partly lord }\end{array}$ & $\begin{array}{l}\text { Partly self-control, } \\
\text { partly lord }\end{array}$ & $\begin{array}{l}\text { Partly self-control, } \\
\text { partly lord }\end{array}$ \\
\hline Capitalism & Worker & Capitalist & Capitalist \\
\hline Communism & Self & All & $\begin{array}{l}\text { Partly all, partly indi- } \\
\text { vidual }\end{array}$ \\
\hline
\end{tabular}

Table 2: The main forms of ownership in various modes of production

But how are modes of production related to each other? In a historical way, where they supersede each other, or in a historical-logical way within a specific social formation that sublates older formations but encompasses older modes of production into itself? Jairus Banaji (2011) argues that Stalinism and vulgar Marxism have conceptualised the notion of the mode of production based on the assumption that a specific mode contains only one specific historical form of labour and surplus-value appropriation and eliminates previous modes so that history develops in the form of a linear evolution: slavery $\rightarrow$ feudalism $\rightarrow$ capitalism $\rightarrow$ communism. So for example Althusser and Balibar (1970) argue that the historical development of society is non-dialectical and does not involve sublations, but rather transitions "from one mode of production to another" (Althusser and Balibar 1970, 307) so that one mode succeeds the other. This concept of history is one of the reasons why E.P. Thompson (1978, 131) has characterized Althusser's approach as "Stalinism at the level of theory". The Stalinist "metaphysical-scholastic formalism" (Banaji 2011, 61) has been reproduced in liberal theory's assumption that there is an evolutionary historical development from the agricultural society to the industrial society to the information society so that each stage eliminates the previous one (as argued by: Bell 1974; Toffler 1980), which shows that in the realm of theory 
some liberals of today share in their theory elements of Stalinism. According to Banaji, capitalism often intensified feudal or semi feudal production relations. In parts of Europe and outside, feudalism would have only developed as a "commodity-producing enterprise" (Banaji $2011,88)$. In the Islamic world capitalism would have developed without slavery and feudalism (Banaji 2011, 6).

Banaji advances in contrast to formalist interpretations a complex reading of Marx's theory, in which a mode of production is "capable of subsuming often much earlier forms" (Banaji 2011,1 ), "similar forms of labour-use can be found in very different modes of production" (6), capitalism is "working through a multiplicity of forms of exploitation" (145) and is a combined form of development (358) that integrates "diverse forms of exploitation and ways of organising labour in its drive to produce surplus value" (359).

A mode of production is a unity of productive forces and relations of production (Marx and Engels 1845/46, 91). If these modes are based on classes as their relations of production, then they have specific contradictions that can via class struggles result in the sublation (Aufhebung) of one mode of production and the emergence of a new one. The emergence of a new mode of production does not necessarily abolish, but rather sublate (aufheben) older modes of production. This means that history is for Marx a dialectical process precisely in Hegel's threefold meaning of the term Aufhebung (sublation): 1) uplifting, 2) elimination, 3) preservation: 1) There are new qualities of the economy, 2) the dominance of an older mode of production vanishes, 3 ) but this older mode continues to exist in the new mode in a specific form and relation to the new mode. The rise of e.g. capitalism however did not bring an end to patriarchy, but the latter continued to exist in such a way that a specific household economy emerged that fulfils the role of the reproduction of modern labour power. A sublation can be more or less fundamental. A transition from capitalism to communism requires a fundamental elimination of capitalism, the question is however if this is immediately possible. Elimination and preservation can take place to differing degrees. A sublation is also no linear progression. It is always possible that relations that resemble earlier modes of organization are created.

Capitalism is at the level of the relations of production organised around relations between capital owners on the one side and paid/unpaid labour and the unemployed on the other side. On the level of the productive forces, it has developed from industrial to informational productive forces. The informational productive forces do not eliminate, but sublate (aufheben) other productive forces (Adorno 1968/2003, Fuchs 2014a, chapter 5): in order for informational products to exist a lot of physical production is needed, which includes agricultural production, mining and industrial production. The emergence of informational capitalism has not virtualised production or made it weightless or immaterial, but is grounded in physical production (Huws 1999, Maxwell and Miller 2012). Whereas capitalism is a mode of production, the terms agricultural society, industrial society and information society characterise specific forms of the organisation of the productive forces (Adorno 1968/2003; Fuchs 2014a, chapter 5).

The new international division of labour (NIDL) organises the labour process in space and time in such a way that specific components of the overall commodity are produced in specific spaces in the global economy and are reassembled in order to form a coherent whole that is sold as a commodity. It thereby can command labour on the whole globe and during the whole day. The approach taken by the authors of this paper advocates a broad understanding of digital labour based on an industry rather than an occupation definition in order to stress the commonality of exploitation, capital as the common enemy of a broad range of workers and the need to globalize and network struggles in order to overcome the rule of capitalism. Some of the workers described in this article are not just exploited by digital media capital, but also and sometimes simultaneously by other forms of capital. It is then a matter of degree to which extent these forms of labour are digital labour and simultaneously other forms of labour. If we imagine a company with job rotation so that each worker on average assembles laptops for $50 \%$ of his/her work time and cars for the other half of the time, a worker in this factory is a digital worker for $50 \%$. S/he is however an industrial worker for $100 \%$ because the content of both manufacturing activities is the industrial assemblage of 
components into commodities. The different forms of digital labour are connected in an international division of digital labour (IDDL), in which all labour necessary for the existence, usage and application of digital media is "disconnected, isolated [...], carried on side by side" and ossified "into a systematic division" (Marx 1867, 456).

Given a model of the mode of production, the question arises how one can best analyze the working conditions in a specific company, industry or sector of the economy when conducting a labour process and class analysis. Which dimensions of labour have to be taken into account in such an analysis? The next section will address this question.

\section{A Typology of the Dimensions of Working Conditions}

A suitable starting point for a systematic model of different dimensions of working conditions is the circuit of capital accumulation as Karl Marx described it $(1867,248-253 ; 1885,109)$. According to Marx, capital accumulation in a first stage requires the investment of capital in order to buy what is necessary for producing commodities, the productive forces: labour time of workers ( $L$ or variable capital) on the one hand, and working equipment like machines and raw materials (MoP or constant capital) on the other hand (Marx 1885/1992, 110). Thus, money $(\mathrm{M})$ is used in order to buy labour power as well as machines and resources as commodities $(C)$ that then in a second stage enter the labour process and produce $(P)$ a new commodity (C') (Marx 1885, 118). This new commodity $\left(C^{\prime}\right)$ contains more value than the sum of its parts, i.e. surplus value. This surplus value needs to be realized and turned into more money (M') by selling the commodity in the market (Marx 1885/1992, 125). The circuit of capital accumulation can thus be described with the following formula:

$$
M \rightarrow C \ldots P \ldots C^{\prime} \rightarrow M^{\prime}(\operatorname{Marx} 1885,110)
$$

According to Marx, surplus value can only be generated due to the specific qualities of labour-power as a commodity. Marx argued that labour power is the only commodity "whose use-value possesses the peculiar property of being a source of value, whose actual consumption is therefore itself an objectification of labour, hence a creation of value" (Marx 1867, 270).

Labour is thus essential to the process of capital accumulation. The model in figure 7 takes the labour process as its point of departure for identifying different dimensions that shape working conditions (Sandoval 2013). The purpose of this model is to provide comprehensive guidelines that can be applied for systematically studying working conditions in different sectors (for a systematic study of corporate irresponsibility of working and production conditions in 8 companies in the media industries see Sandoval 2014). 


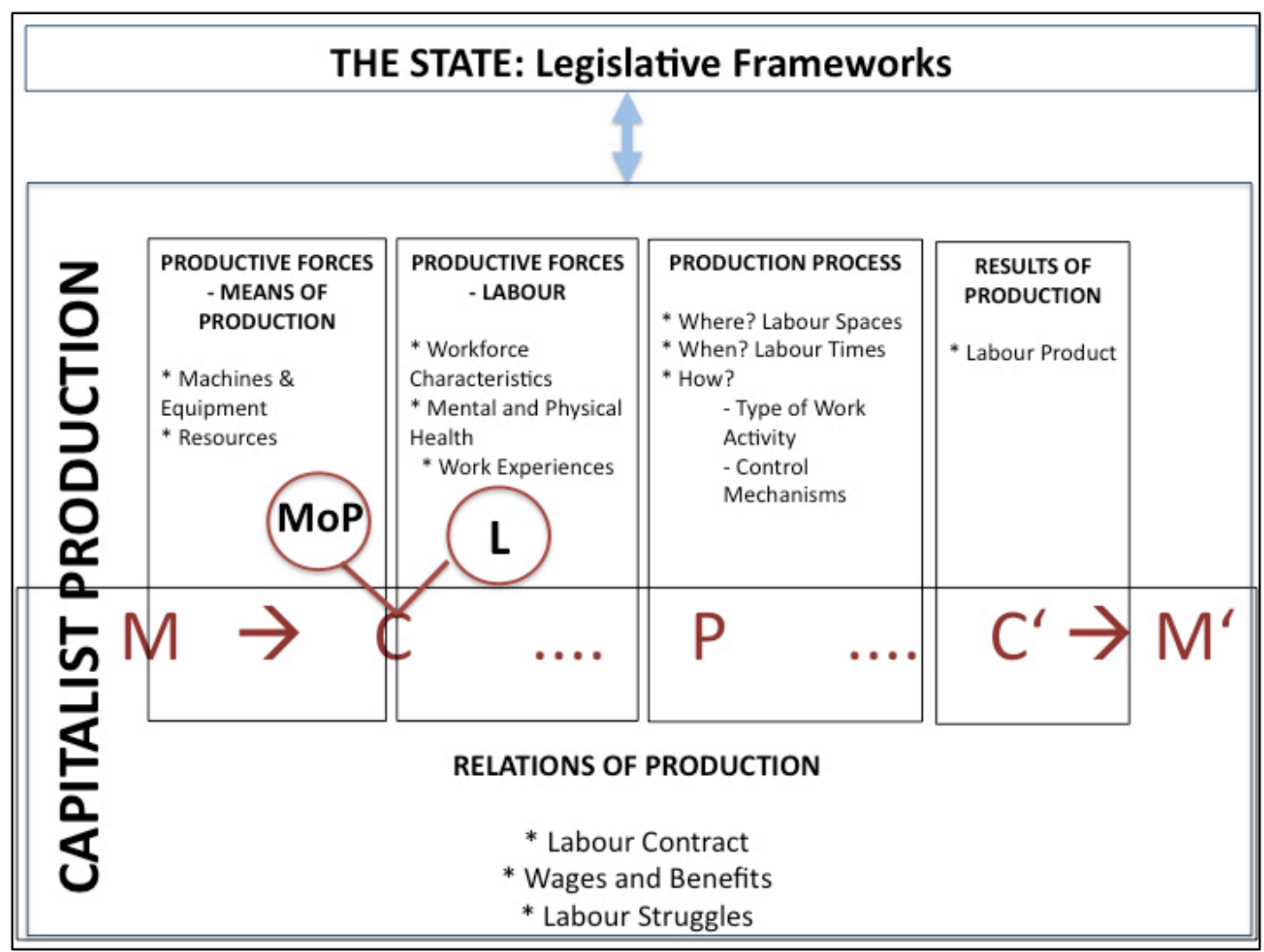

Figure 8: Dimensions of working conditions

The model pictured in figure 8 identifies five areas that shape working conditions throughout the capital accumulation process: means of production, labour, relations of production, the production process and the outcome of production. Furthermore this model includes the state's impact on working conditions through labour legislation:

- Productive Forces-Means of Production: Means of production include machines and equipment on the one hand and resources that are needed for production on the other hand. The question whether workers operate big machines, work at the assembly line, use mobile devices such as laptops, handle potentially hazardous substances, use high-tech equipment, traditional tools or no technology at all etc. shapes the experience of work and has a strong impact on work processes and working conditions.

- Productive Forces-Labour: The subjects of the labour process are workers themselves. One dimension that impacts work in a certain sector is the question how the workforce is composed in terms of gender, ethnic background, age, education levels etc. Another question concerns worker health and safety and how it is affected by the means of production, the relations of production, the labour process, and labour law. Apart from outside impacts on the worker, an important factor is how workers themselves experience their working conditions.

- Relations of Production: Within capitalist relations of production, capitalists buy labour power as a commodity. Thereby a relation between capital and labour is established. The purchase of labour power is expressed through wages. Wages are the primary means of subsistence for workers and the reason why they enter a wage labour relation. The level of wages thus is a central element of working conditions. Labour contracts specify the conditions under which capital and labour enter this relation, including working hours, wages, work roles and responsibilities etc. The content of this contract is subject to negotiations and often struggles between capital and labour. The relation between capital and labour is thus established through a wage relation and formally enacted by a labour contract that is 
subject to negotiations and struggles. These three dimensions of the relation between capital and labour set the framework for the capitalist labour process.

- Production process: Assessing working conditions, furthermore, requires looking at the specifics of the actual production process. A first factor in this context is its spatial location. Whether it is attached to a certain place or is location independent, whether it takes place in a factory, an office building, or outdoors etc. are important questions. A second factor relates to the temporal dimension of work. Relevant questions concern the amount of regular working hours and overtime, work rhythms, the flexibility or rigidness of working hours, the relation between work time and free time etc. Finally working conditions are essentially shaped by how the production process is executed. This includes on the one hand the question which types of work activity are performed. The activities can range from intellectual work, to physical work, to service work, from skilled to unskilled work, from creative work to monotonous and standardized work tasks, etc. On the other hand another aspect of the production process is how it is controlled and managed. Different management styles can range from strict control of worker behaviour and the labour process to high degrees of autonomy, self-management or participatory management etc. Space, time, activity and control are essential qualities of the production process and therefore need to be considered when studying working conditions.

- Product: Throughout the production process workers put their time, effort and energy into producing a certain product. This actual outcome of production and how it relates back to the worker thus needs to be considered for understanding work in a certain sector.

- The state: Finally the state has an impact on working conditions through enacting labour laws that regulate minimum wages, maximum working hours, social security, safety standards etc.

Table 3 summarizes the dimensions of working conditions that we described above.

\begin{tabular}{|c|c|c|}
\hline \multirow[t]{2}{*}{$\begin{array}{l}\text { Productive forces - Means of } \\
\text { production }\end{array}$} & Machines and equipment & $\begin{array}{l}\text { Which technology is being } \\
\text { used during the production } \\
\text { process? }\end{array}$ \\
\hline & Resources & $\begin{array}{l}\text { What resources are used } \\
\text { during the production pro- } \\
\text { cess? }\end{array}$ \\
\hline \multirow[t]{3}{*}{ Productive forces - Labour } & Workforce characteristics & $\begin{array}{l}\text { What are important charac- } \\
\text { teristics of the workforce for } \\
\text { example in terms of age, } \\
\text { gender, ethnic background } \\
\text { etc? }\end{array}$ \\
\hline & Mental and physical health & $\begin{array}{l}\text { How do the employed means } \\
\text { of production and the labour } \\
\text { process impact mental and } \\
\text { physical health of workers? }\end{array}$ \\
\hline & Work experiences & $\begin{array}{l}\text { How do workers experience } \\
\text { their working conditions? }\end{array}$ \\
\hline \multirow[t]{3}{*}{ Relations of production } & Labour contracts & $\begin{array}{l}\text { Which type of contracts do } \\
\text { workers receive, what do } \\
\text { they regulate? }\end{array}$ \\
\hline & Wages and benefits & $\begin{array}{l}\text { How high/low are wage lev- } \\
\text { els and what are other mate- } \\
\text { rial benefits for workers? }\end{array}$ \\
\hline & Labour struggles & $\begin{array}{l}\text { How do workers organize } \\
\text { and engage in negotiations } \\
\text { with capital and what is the } \\
\text { role of worker protests? }\end{array}$ \\
\hline
\end{tabular}




\begin{tabular}{|l|l|l|}
\hline Production process & Labour spaces & $\begin{array}{l}\text { Where does the production } \\
\text { process take place? }\end{array}$ \\
\cline { 3 - 3 } & Labour times & $\begin{array}{l}\text { How many working hours are } \\
\text { common within a certain } \\
\text { sector, how are they en- } \\
\text { forced and how is the rela- } \\
\text { tionship between work and } \\
\text { free time? }\end{array}$ \\
\cline { 3 - 4 } & Work activity & $\begin{array}{l}\text { Which type of mental and/or } \\
\text { physical activity are workers } \\
\text { performing? }\end{array}$ \\
\cline { 3 - 4 } & Control mechanism & $\begin{array}{l}\text { Which type of mechanisms } \\
\text { are in place that control the } \\
\text { behaviour of workers? }\end{array}$ \\
\hline Results of production & $\begin{array}{l}\text { Which kinds of products or } \\
\text { services are being pro- } \\
\text { duced? }\end{array}$ \\
\hline The state & Labour product & $\begin{array}{l}\text { Which regulations regarding } \\
\text { minimum wages, maximum } \\
\text { working hours, safety, social } \\
\text { security etc are in place and } \\
\text { how are they enforced? }\end{array}$ \\
\hline
\end{tabular}

Table 3: Dimensions of working conditions

Given an identification of dimensions of working conditions, we can next bring this typology together with aspects of digital labour.

\section{The Conditions of Digital Labour}

In section 1, we introduced a cultural-materialist model of cultural work (figure 1) that distinguishes between physical cultural work and information work. Figure 8 is an application of this model to the realm of digital labour: digital labour is a special form of cultural work that results in the production and use of digital media. It distinguishes three forms of digital labour that represent different modes of the organisation of the productive forces: agricultural digital labour, industrial digital labour, informational digital labour. They are articulations of the three organisation forms of the productive forces that we identified in table 1: agricultural, industrial and informational productive forces. Agricultural and industrial digital work/labour are forms of physical cultural work/labour in the context of digital media. Informational digital work/labour is an expression of information work in the realm of digital media production.

Figure 9 shows a model of the major production processes that are involved in digital labour. Each production step/labour process involves human subjects (S) using technologies/instruments of labour $(\mathrm{T})$ on objects of labour $(\mathrm{O})$ so that a product emerges. The very foundation of digital labour is an agricultural labour cycle in which miners extract minerals. These minerals enter the next production process as objects so that processors based on them in physical labour processes create ICT components. These components enter the next labour cycle as objects: assemblage workers build digital media technologies and take ICT components as inputs. Processors and assemblers are industrial workers involved in digital production. The outcome of such labour are digital media technologies that enter various forms of information work as tools for the production, distribution, circulation, prosumption, and consumption of diverse types of information. 


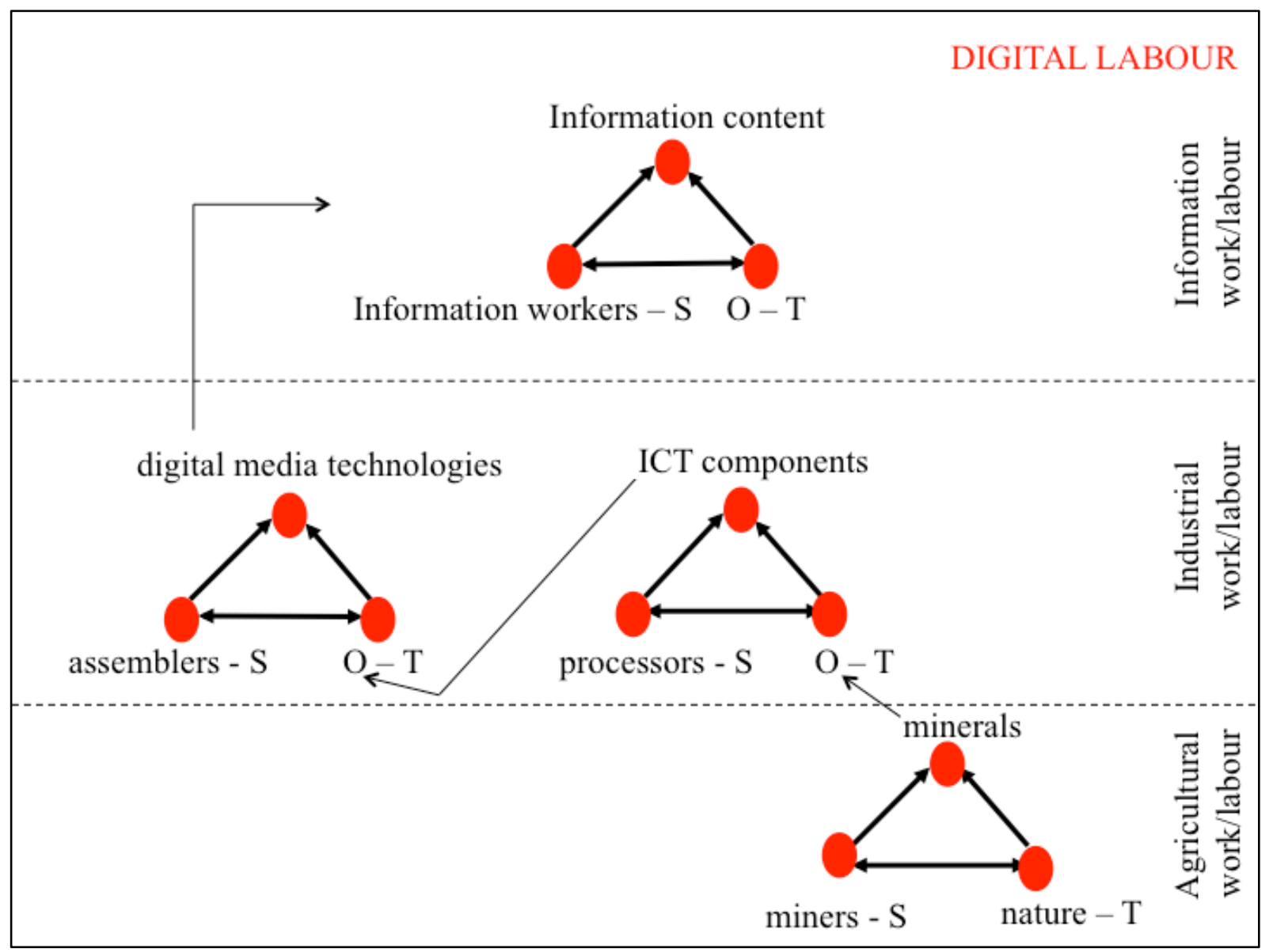

Figure 9: The complex network of cycles of digital labour

"Digital labour" is not a term that only describes the production of digital content. We rather use the term in a more general sense for the whole mode of digital production that contains a network of agricultural, industrial and informational forms of work that enables the existence and usage of digital media. The subjects involved in the digital mode of production (S) miners, processors, assemblers, information workers and related workers-stand in specific relations of production that are either class relations or non-class relations. So what we designate as $S$ in figure 8 is actually a relationship $S_{1}-S_{2}$ between different subjects or subject groups. In contemporary capitalist society, most of these digital relations of production tend to be shaped by wage labour, slave labour, unpaid labour, precarious labour, and freelance labour.

In section 2, we introduced a model of the work process in general (figures 4, 6, 7; tables $1,2)$. Section 3 presented a model for the analysis of capitalist working conditions in capitalism (table 3, figure 8). How are these two models connected? The first one is more general and presents typologies for all modes of production (patriarchy, slavery, feudalism, capitalism, communism) and productive forces (agricultural, industrial, informational). The second model shown in figure 8 and table 3 shows dimension of labour within the capitalist mode of production. Table 4 shows how elements in model 1 (figure 4 ) correspond to elements in model 2 (figure 8 , table 3 ). 


\begin{tabular}{|c|c|c|}
\hline \multicolumn{2}{|l|}{ MODEL 2 (figure 8, table 3) } & MODEL 1 (figure 4) \\
\hline \multirow{2}{*}{$\begin{array}{l}\text { Productive forces - Means } \\
\text { of production }\end{array}$} & Machines and equipment & Object: Instruments of labour \\
\hline & Resources & Object: Object of labour \\
\hline \multirow[t]{3}{*}{ Productive forces - Labour } & Workforce characteristics & Subject \\
\hline & Mental and physical health & Subject \\
\hline & Work experiences & Subject \\
\hline \multirow[t]{3}{*}{ Relations of production } & Labour contracts & $\begin{array}{l}\text { Subject-subject relation- } \\
\text { ships: Relations of produc- } \\
\text { tion }\end{array}$ \\
\hline & Wages and benefits & $\begin{array}{l}\text { Subject-subject relation- } \\
\text { ships: Relations of produc- } \\
\text { tion }\end{array}$ \\
\hline & Labour struggles & $\begin{array}{l}\text { Subject-subject relation- } \\
\text { ships: Relations of produc- } \\
\text { tion }\end{array}$ \\
\hline \multirow[t]{4}{*}{ Production process } & Labour spaces & Object: Instruments of labour \\
\hline & Labour times & $\begin{array}{l}\text { Subject-subject relation- } \\
\text { ships: Relations of produc- } \\
\text { tion }\end{array}$ \\
\hline & Work activity & Subject \\
\hline & Control mechanism & $\begin{array}{l}\text { Subject-subject relation- } \\
\text { ships: Relations of produc- } \\
\text { tion }\end{array}$ \\
\hline Results of production & Labour product & $\begin{array}{l}\text { Subject-object: Products of } \\
\text { labour }\end{array}$ \\
\hline The state & Labour law & $\begin{array}{l}\text { Subject-subject relation- } \\
\text { ships: Relations of produc- } \\
\text { tion }\end{array}$ \\
\hline
\end{tabular}

Table 4: Dimensions of working conditions

We have developed a systematic digital labour analysis toolkit that helps asking systematic questions about the involved labour processes. It can be applied to agricultural, industrial and informational digital labour and combinations of these forms of work. Table 5 presents the digital labour analysis toolkit that is based on the more general model introduced in table 3. 


\begin{tabular}{|c|c|c|c|}
\hline \multirow[t]{2}{*}{$\begin{array}{l}\text { Productive } \\
\text { forces - } \\
\text { Means of } \\
\text { production }\end{array}$} & $\begin{array}{l}\text { Machines and } \\
\text { equipment }\end{array}$ & $\begin{array}{l}\text { What technologies or } \\
\text { combinations thereof are } \\
\text { being used during the ag- } \\
\text { ricultural, industrial and } \\
\text { informational production } \\
\text { process that create digital } \\
\text { media and contents? }\end{array}$ & $\begin{array}{l}\text { a) non-digital machines } \\
\text { b) digital machines } \\
\text { c) human brain } \\
\text { d) human hands }\end{array}$ \\
\hline & Resources & $\begin{array}{l}\text { What resources or combi- } \\
\text { nations thereof are used } \\
\text { during the agricultural, } \\
\text { industrial and information- } \\
\text { al production processes of } \\
\text { digital media and content? }\end{array}$ & $\begin{array}{l}\text { a) physical resources: natural } \\
\text { resources } \\
\text { b) digital and mediated da- } \\
\text { ta/information } \\
\text { c) human ideas } \\
\text { d) physical resources: indus- } \\
\text { trial resource }\end{array}$ \\
\hline \multirow[t]{3}{*}{$\begin{array}{l}\text { Productive } \\
\text { forces - La- } \\
\text { bour }\end{array}$} & $\begin{array}{l}\text { Workforce } \\
\text { characteristics }\end{array}$ & $\begin{array}{l}\text { What are important char- } \\
\text { acteristics of the workforce } \\
\text { in agricultural, industrial } \\
\text { and informational digital } \\
\text { labour (for example in } \\
\text { terms of age, gender, eth- } \\
\text { nic background etc)? }\end{array}$ & $\begin{array}{l}\text { a) class } \\
\text { b) gender } \\
\text { b) age } \\
\text { c) ethnicity } \\
\text { d) abilities } \\
\text { e) education, } \\
\text { etc. }\end{array}$ \\
\hline & $\begin{array}{l}\text { Mental and } \\
\text { physical health }\end{array}$ & $\begin{array}{l}\text { How do the employed } \\
\text { means of production and } \\
\text { the labour process impact } \\
\text { mental and physical health } \\
\text { of agricultural, industrial } \\
\text { and informational digital } \\
\text { workers? }\end{array}$ & $\begin{array}{l}\text { a) mental health } \\
\text { b) physical health }\end{array}$ \\
\hline & $\begin{array}{l}\text { Work experi- } \\
\text { ences }\end{array}$ & $\begin{array}{l}\text { How do agricultural, indus- } \\
\text { trial and informational digi- } \\
\text { tal workers experience } \\
\text { their working conditions? }\end{array}$ & \\
\hline \multirow[t]{2}{*}{$\begin{array}{l}\text { Relations of } \\
\text { production }\end{array}$} & $\begin{array}{l}\text { Labour con- } \\
\text { tracts }\end{array}$ & $\begin{array}{l}\text { Are there labour contracts } \\
\text { or not? In the case, where } \\
\text { there are labour contracts: } \\
\text { Which type of contracts do } \\
\text { digital workers receive, } \\
\text { what do they regulate? }\end{array}$ & $\begin{array}{l}\text { a) no contract, } \\
\text { b) written/oral contract, } \\
\text { c) part-time or full-time em- } \\
\text { ployment contract, } \\
\text { d) permanent or temporary } \\
\text { employment contract, } \\
\text { e) employment or service } \\
\text { contract, } \\
\text { f) freelancer or employee, } \\
\text { etc. }\end{array}$ \\
\hline & $\begin{array}{l}\text { Wages and } \\
\text { benefits }\end{array}$ & $\begin{array}{l}\text { Are there wages and spe- } \\
\text { cific benefits digital work- } \\
\text { ers enjoy or not? In case, } \\
\text { where there are wages } \\
\text { and benefits: How } \\
\text { high/low are wage levels } \\
\text { and what are other mate- } \\
\text { rial benefits for digital }\end{array}$ & $\begin{array}{l}\text { a) wage level } \\
\text { b) included/excluded health } \\
\text { benefits } \\
\text { c) included/excluded retire- } \\
\text { ment insurance } \\
\text { (state/private/company/mixed } \\
\text { insurance) } \\
\text { d) included/excluded unem- }\end{array}$ \\
\hline
\end{tabular}




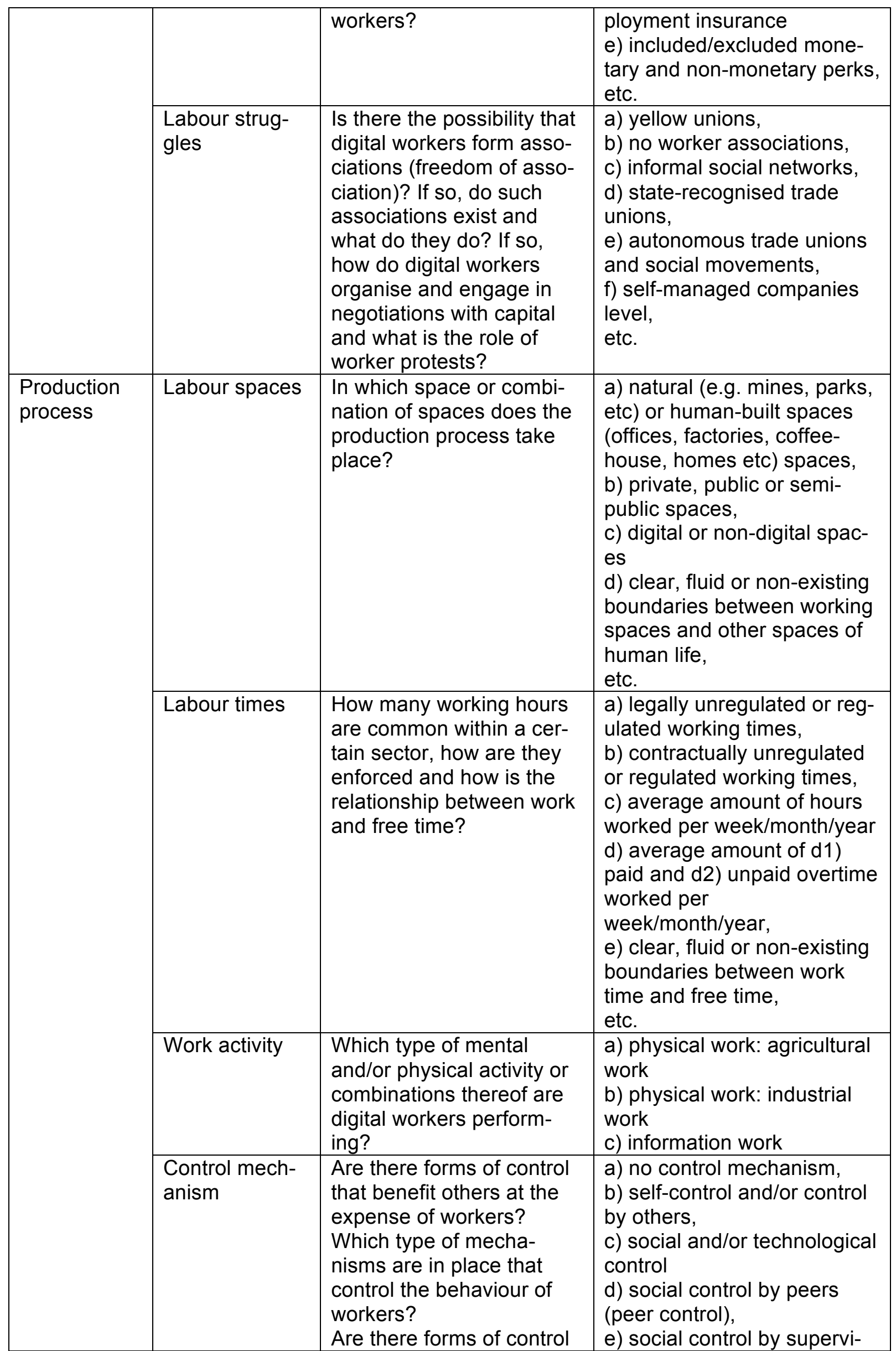




\begin{tabular}{|c|c|c|c|}
\hline & & $\begin{array}{l}\text { that control the control- } \\
\text { lers? }\end{array}$ & $\begin{array}{l}\text { sors and mangers, } \\
\text { f) digital or non-digital tech- } \\
\text { nological control, } \\
\text { g) surveillance of applicants, } \\
\text { workplace, workforce, output, } \\
\text { activities, property, consum- } \\
\text { ers, prosumers, competitors, } \\
\text { h) controls that are inherent } \\
\text { to production technologies, } \\
\text { controls that are external (i.e. } \\
\text { separate control technolo- } \\
\text { gies), } \\
\text { g) forms of counter-control } \\
\text { (corporate watchdogs, work- } \\
\text { place inspectors, }\end{array}$ \\
\hline $\begin{array}{l}\text { Results of } \\
\text { production }\end{array}$ & Labour product & $\begin{array}{l}\text { Which kinds of products or } \\
\text { services does digital la- } \\
\text { bour produce? }\end{array}$ & $\begin{array}{l}\text { a) digital or non-digital prod- } \\
\text { ucts, } \\
\text { b) online or offline products, } \\
\text { c) physical (agricultural, in- } \\
\text { dustrial) and/or informational } \\
\text { and/or social (-service) prod- } \\
\text { uct, etc. }\end{array}$ \\
\hline The state & $\begin{array}{l}\text { Labour legisla- } \\
\text { tion }\end{array}$ & $\begin{array}{l}\text { Are there state laws that } \\
\text { regulate work? Which reg- } \\
\text { ulations regarding mini- } \\
\text { mum wages, maximum } \\
\text { working hours, safety, so- } \\
\text { cial security etc are in } \\
\text { place and how are they } \\
\text { enforced? }\end{array}$ & $\begin{array}{l}\text { a) Regulation and enforce- } \\
\text { ment of work and service } \\
\text { contracts, legal dispute reso- } \\
\text { lution } \\
\text { b) Wage legislation: } \\
\text { wage protections, minimum } \\
\text { wage regulation, etc, } \\
\text { c) Work time legislation: } \\
\text { standard working times, max- } \\
\text { imum working hours, over- } \\
\text { time regulations, } \\
\text { annual leave, sabbatical } \\
\text { leave, on-the-job-training } \\
\text { times and further education, } \\
\text { flexible working, termination } \\
\text { of employment (protection } \\
\text { from unfair dismissal, redun- } \\
\text { dancy payments, } \\
\text { etc), etc. } \\
\text { d) Health and safety legisla- } \\
\text { tion: } \\
\text { work space regulations, work } \\
\text { equipment and resources } \\
\text { regulations, dangerous sub- } \\
\text { stances, protective gear, etc. } \\
\text { e) Social security benefit } \\
\text { legislation: } \\
\text { parental leave, unemploy- } \\
\text { ment, pension, health care, } \\
\text { etc. } \\
\text { f) Employee representation } \\
\text { and freedom of association, }\end{array}$ \\
\hline
\end{tabular}




\begin{tabular}{|l|l|l|}
\hline & & g) Taxation: \\
& & $\begin{array}{l}\text { corporation tax, income and } \\
\text { wage tax, etc; } \\
\text { etc. }\end{array}$ \\
\hline
\end{tabular}

Table 5: Digital labour analysis toolkit

Case studies and the analysis of digital labour shows that digital labour is a global network of various forms of labour that represent various interlinked modes of production and various levels of organization of the productive forces (Fuchs 2014a). Examples are African slave workers who mine minerals that are used for the production of digital media components, Tayloristic ICT hardware assemblers working under Taylorist and hazardous conditions in toxic workplaces, highly paid and highly stressed software engineers and knowledge professionals, precarious digital media freelancers, Taylorised call centre workers, unpaid social media prosumers creating personal data commodities for social media corporations etc (Fuchs 2014a). These working conditions reflect various modes of production such as slavery, patriarchy and capitalism, various forms of the organization of the capitalist mode of production (Fordist/Taylorist labour, post-Fordist labour, etc) different organization forms of the productive forces and the labour conducted in it (agricultural labour, industrial labour, informational labour).

Jairus Banaji's (2011) stresses that Marx's theory of the mode of production shows that "capitalist relations of production are compatible with a wide variety of forms of labour, from chattel-slavery, sharecropping, or the domination of casual labour-markets, top the coerced wage-labour peculiar to colonial regimes and, of course, 'free' wage-labour" (Banaji 2011, 359). Banaji's concept of the mode of production matters for understanding the digital media economy because in this economy a variety of modes of production and organisations of the productive forces (=variations within a specific mode of production) are articulated, including slavery in mineral extraction, military forms of Taylorist industrialism in hardware assemblage, an informational organisation of the productive forces of capitalism that articulates a highly paid knowledge labour aristocracy, precarious service workers as well as imperialistically exploited knowledge workers in developing countries; industrial recycling and management of e-waste as well as highly hazardous informal physical e-waste labour (Fuchs 2014a).

Digital media are information technologies. So although they are created by physical, agricultural and scientific development work, they are used and applied as tools of cognition, communication and collaboration and therefore have a crucial cultural dimension of usage, work and labour (Fuchs 2014b).

The upper level of information work in figure 8 is an important dimension of digital labour. It contains those digital workers who create digital content. They are digital content/information workers. Table 6 presents a typology for classifying digital information work. The table identifies 8 specific dimensions of digital information work. These eight dimensions are elements of the capital accumulation process in the digital content industry: There is 1) a human subject engaging in work, 2) a capitalist looking for making profits, 3) a contractual economic relationship, 4) technologies as instruments/means of production, 5) resources as means/objects of production, 6 ) the output of production (the product), 7 ) the distribution of products, 8 ) the consumption of products. 


\begin{tabular}{|c|c|c|c|c|c|c|c|}
\hline $\begin{array}{l}\text { Infor- } \\
\text { mation } \\
\text { worker's } \\
\text { job- } \\
\text { seeking } \\
\text { strategy }\end{array}$ & $\begin{array}{l}\text { Employ- } \\
\text { er, con- } \\
\text { tractor }\end{array}$ & $\begin{array}{l}\text { Relations } \\
\text { of pro- } \\
\text { duction }\end{array}$ & $\begin{array}{l}\text { Technolo- } \\
\text { gy }\end{array}$ & Objects & $\begin{array}{l}\text { Prod- } \\
\text { ucts }\end{array}$ & $\begin{array}{l}\text { Distri- } \\
\text { bution }\end{array}$ & $\begin{array}{l}\text { Con- } \\
\text { sump- } \\
\text { tion }\end{array}$ \\
\hline 1 online & 1 online & 1 online & 1 brain & 1 digital & 1 digital & 1 online & 1 digita \\
\hline \multirow[t]{3}{*}{2 offline } & 2 offline & 2 offline & $\begin{array}{l}2 \text { brain }+ \\
\text { digital } \\
\text { technolo- } \\
\text { gies }\end{array}$ & $\begin{array}{l}2 \text { non- } \\
\text { digital }\end{array}$ & $\begin{array}{l}2 \text { non- } \\
\text { digital }\end{array}$ & 2 offline & $\begin{array}{l}2 \text { non- } \\
\text { digital }\end{array}$ \\
\hline & & 3 blended & $\begin{array}{l}3 \text { brain }+ \\
\text { non-digital } \\
\text { technolo- } \\
\text { gies }\end{array}$ & $\begin{array}{l}3 \text { blend- } \\
\text { ed }\end{array}$ & $\begin{array}{l}3 \text { blend- } \\
\text { ed }\end{array}$ & & \\
\hline & & & $\begin{array}{l}4 \text { brain }+ \\
\text { digital } \\
\text { technolo- } \\
\text { gies }+ \text { non- } \\
\text { digital } \\
\text { technolo- } \\
\text { gies }\end{array}$ & & & & \\
\hline
\end{tabular}

Table 6: A typology of the digitalisation of information labour

Digital information labour can take on different forms. A first important dimension is how information workers find jobs, projects or employment. The information worker can have an online profile/website/blog etc or not in order to find work. Also the employer/contractor can have an online profile/website/blog etc or not. It is of course likely that those workers and employers who present themselves online and look for economic relations online do so also offline. They then fall into the category " 1 online". The distinction here wants to draw a separation line between those who use the Internet for establishing economic relations and those who do not. The relationship between the two can be established and maintained primarily online (e.g. via platforms such as Amazon Mechanical Turk, oDesk or PeoplePerHour), offline or in a blended way. The technologies used for production always involve the brain because we talk about information work. But in addition also digital tools and/or non-digital tools can be used as means of production. The objects on which the labour is conducted can either be entirely digital, non-digital or both digital and non-digital. The created products can be digital, non-digital or a mix of both. Their distribution and consumption can take place online or offline. This means that there are 8 dimensions of digital information labour that can have various characteristics. The number of logical forms of digital information labour can be calculated by multiplying various binominal coefficients: 


$$
\begin{aligned}
& \left(\begin{array}{l}
2 \\
1
\end{array}\right) *\left(\begin{array}{l}
2 \\
1
\end{array}\right) *\left(\begin{array}{l}
3 \\
1
\end{array}\right) *\left(\begin{array}{l}
4 \\
1
\end{array}\right) *\left(\begin{array}{l}
3 \\
1
\end{array}\right) *\left(\begin{array}{l}
3 \\
1
\end{array}\right) *\left(\begin{array}{l}
2 \\
1
\end{array}\right) *\left(\begin{array}{l}
2 \\
1
\end{array}\right) \\
& \left(\begin{array}{l}
n \\
k
\end{array}\right)=\frac{n !}{k ! *(n-k) !} \\
& \left(\begin{array}{l}
2 \\
1
\end{array}\right)=\frac{2 !}{1 ! * 1 !}=2 \\
& \left(\begin{array}{l}
3 \\
1
\end{array}\right)=\frac{3 !}{1 ! * 2 !}=3 \\
& \left(\begin{array}{l}
4 \\
1
\end{array}\right)=\frac{4 !}{1 ! * 3 !}=4
\end{aligned}
$$

$2 * 2 * 3 * 4 * 3 * 3 * 2 * 2=1728$

So from a purely logical point of view, there are 1728 different possible forms of digital information labour. Which of them occur in actual reality or are in a logically feasible manner included into the category of digital information labour is an empirical and theoretical question. These 1728 possibilities represent the productive forces of digital information work that are embedded into and interact with specific relations of production. Annex A presents a full list of all 1728 logically possible forms of digital information labour.

It is a theoretical question if all of these forms of labour are digital labour or if only those that satisfy a minimum number of characteristics that are digital should be considered as digital labour. Or should all activities characterised by the typology that contain at least one dimension that is digital be considered as forms of digital labour? The typology shows in any case that it is possible to observe and with this typology characterise the digitalisation or informatisation of various dimensions of work, such as the way people look for jobs and employment, employers' search for labour power, the relations of production, the technological means of production, the used resources, the created products, forms of distribution, and forms of consumption. Rudi Schmiede (1996) uses the term informatisation of work for describing how information technologies shape the work process. He does not limit the term to the computerisation of work, but mentions other information technologies, such as the postal service, the telegraph, double bookkeeping, books of accounts, or file card systems (Schmiede 1996, 122). The computerisation or digitalisation of work is one specific form of the informatisation of work: digital media technologies shape various aspects of different forms of work. Schmiede says the fact that computer technologies enable the networking of information has resulted in a form of abstract societalisation (Vergesellschaftung) in capitalism: all forms of work could in principle be shaped and influenced by the networked computer so that "the informatisation of societal work opens access for the measure of value and valorisation to each individual work that is integrated into an in principle global information context" (Schmiede 1996, 125, translation from German ${ }^{1}$ ). The typology in table 6 describes various dimensions of the digitalisation or networked computerisation of labour. It is a theoretical question which of these forms of labour should be termed digital information labour and which ones should not.

Let us consider an example: a blogger who generates postings for a newspaper's website and works from home. She conducts her work primarily online, i.e. she blogs on the Internet, and her employer's presence for her is its newspaper website. The communication between the blogger and the newspaper's online editor takes place primarily online, but from time to time there are real life meetings in order to discuss the newspaper's online strategy. So the production relationship has a blended character. The blogger uses her brain and digital tech-

\footnotetext{
1 „Allgemein gesagt, eröffnet die Informatisierung der gesellschaftlichen Arbeit dem Wert- und Verwertungsmaßstab den Zugriff auf jede einzelne Arbeit, die in einen prinzipiell globalen Inforamtionszusammenhang eingegliedert ist".
} 
nologies such as a laptop connected to the Internet and a blogging platform, so the used technologies are a human brain and digital technologies. The objects of work are the blogger's experiences, opinions and thoughts (non-digital information) and other online documents to which she links (digital), so the objects of work are blended. The product is a digital text that is distributed and consumed online in digital format. Using the typology in table 4, we can characterize the blogger's work as an example of digital information work version number 11323111 . This characterisation of digital information work makes use of eight symbolic positions: each describes one dimension of digital information work according to table 6. Each dimension's expression is defined according to the codes in table 6 . The typology in table 6 describes various dimensions of the digitalisation or networked computerisation of labour. It is a theoretical question which of these forms of labour should be termed digital information labour and which ones should not.

\section{Conclusion}

In this paper, we have introduced a cultural-materialist approach for theorising digital labour. Many approaches are idealist in that they define concepts such as digital labour, virtual work, online work, cyberwork, immaterial labour, knowledge labour, creative work, cultural labour, communicative labour, information(al) work, digital craft, service work, prosumption, consumption work, audience labour, playbour, etc., only as an externalisation of human ideas that are objectified in contents and thereby neglect that this labour is based on and only possible because there is a global division of labour, in which many different forms of labour are conducted under specific modes of production. We have used Raymond Williams' framework of cultural materialism for arguing that we should overcome digital idealism and analyse digital labour based the framework of digital materialism.

We have introduced specific concepts for a digital materialist theory of digital labour: cultural work, physical cultural work, information work, modes of production, productive forces, relations of production, digital work, digital labour, physical digital work/labour (agricultural digital work/labour, industrial digital work/labour), informational digital work/labour. Furthermore we have suggested a digital labour analysis toolbox that distinguishes elements of digital labour processes and can be used as framework for the concrete empirical analysis of specific forms of digital work/labour. Conducting such analyses often faces the problem of what the elements of analysis are. We argue for avoiding particularistic analyses that focus only on single elements of single production processes and for conducting holistic analyses that focus on the totality of elements and networks that determine and shape digital labour. The toolkit allows analysing the totality of elements of elements of digital labour processes. Digital labour analysis should also look at how one specific form of digital labour that is analysed is connected to and articulated with other forms of digital labour that express certain organisational forms of the productive forces and the relations of production.

The world of digital media is shaped by a complex global articulation of various modes of production that together constitute the capitalist mode of creating and using digital media. The digital tools that we use for writing, reading, communicating, uploading, browsing, collaborating, chatting, befriending, or liking are embedded into a world of exploitation. Yet most of us cannot and do not want to imagine a world without digital media. So the alternative is not digital Luddism, but political praxis.

Digital labour analysis can only interpret the digital media world; the point is to change it. Change can only be good change if it is informed change. Critical theory can inform potential and actual struggles for a better world. Everyday working realities of different people and in different parts of the world look so heterogeneous, different and unconnected that it is often difficult to see what they have in common. Digital labour theory and digital labour analysis can help to identify and make visible the common and different experiences of suffering and enjoyment, pleasure and pain, security and insecurity, alienation and appropriation, exploitation and resistance, creativity and toil. It is in this respect a digital sociology of critique. But it is at the same time also a political philosophy, a critical digital sociology that helps identifying and clarifying foundations and germ forms of a better future and grounding judgements about 
what is good and bad in the context of digital media. Digital labour theory and analysis therefore takes on the role of a critical sociology of critique that is both at once a critical sociology and a sociology of critique (Boltanski and Honneth 2009). It analyses the reality of life under digital capitalism, contributes intellectually to questioning this mode of human existence in order to show that there is and to help realise life beyond capitalism.

\section{References}

Adorno, Theodor W. 1968/2003. Late Capitalism or Industrial Society? The Fundamental Question of the Present Structure of Society. In Can One Live After Auschwitz?, edited by Rolf Tiedemann, 111-125. Stanford: Stanford University Press.

Althusser, Louis and Étienne Balibar. 1970. Reading Capital. London: NLB.

Andrejevic, Mark. 2012. Exploitation in the Data Mine. In Internet and Surveillance. The Challenges of Web 2.0 and Social Media, edited by Christian Fuchs, Kees Boersma, Anders Albrechtslund and Marisol Sandoval, 71-88. New York: Routledge.

Arendt, Hannah. 1958. The Human Condition. Chicago: University of Chicago Press.

Arvidsson, Adam and Eleanor Colleoni. 2012. Value in Informational Capitalism and on the Internet. The Information Society 28 (3): 135-150.

Banaji, Jairus. 2011. Theory as History. Essays on Modes of Production and Exploitation. Chicago: Haymarket Books.

Bell, Daniel. 1974. The Coming of Post-Industrial Society. London: Heinemann.

Boltanski, Luc and Axel Honneth. 2009. Soziologie der Kritik oder Kritische Theorie? In Was ist Kritik?, edited by Rahel Jaeggi and Tilo Wesche, 81-114. Frankfurt am Main: Suhrkamp.

Caves, Richard E. 2000. Creative Industries. Cambridge: Harvard University Press.

Cunningham, Stuart. 2005. Creative Enterprises. In Creative Industries, edited by John Hartley, 282298. Malden: Blackwell.

D'Mello, Marisa, and Sundeep Sahay. 2007. "I am a Kind of Nomad Where I Have to Go Places and Places" . . . Understanding Mobility, Place and Identity in Global Software Work from India. Information and Organization 17 (3): 162-192.

Engels, Friedrich. 1884. The Origin of the Family, Private Property and the State. Accessed November 10, 2013. http://www.marxists.org/archive/marx/works/1884/origin-family/

Finnwatch. 2007. Connecting Components, Dividing Communities: Tin Production for Consumer Electronics in the DR Congo and Indonesia. makelTfair Report: http://germanwatch.org/corp/it-tin.pdf (accessed August 9, 2013).

Fisher, Eran. 2012. How Less Alienation Creates More Exploitation. tripleC: Communication, Capitalism \& Critique 10 (2): 171-183.

Fröbel, Folker, Jürgen Heinrichs and Otto Kreye. 1981. The New International Division of Labour. Cambridge: Cambridge University Press.

Fuchs, Christian. 2010. Labor in Informational Capitalism and on the Internet. The Information Society 26 (3): 179-196.

Fuchs, Christian. 2012a. Dallas Smythe Today. The Audience Commodity, the Digital Labour Debate, Marxist Political Economy and Critical Theory. Prolegomena to a Digital Labour Theory of Value. tripleC: Capitalism, Communication \& Critique 10 (2): 692-740.

Fuchs, Christian. 2012b. With or Without Marx? With or Without capitalism? A Rejoinder to Adam Arvidsson and Eleanor Colleoni. tripleC: Communication, Capitalism \& Critique: Journal for a Global Sustainable Information Society 10 (2): 633-645.

Fuchs, Christian. 2014a. Digital Labour and Karl Marx. New York: Routledge.

Fuchs, Christian. 2014b. Social Media: A Critical Introduction. London: Sage.

Glass, Robert L. 2006. Software Creativity 2.0. Atlanta, GA: developer. ${ }^{*}$ Books.

Gramsci, Antonio. 1988. The Antonio Gramsci Reader. In Selected Writings 1916-1935, edited by David Forgacs. London: Lawrence and Wishart.

Hartley, John. 2005. Creative Industries. In Creative Industries, 62-76, edited by John Hartley. Malden: Blackwell.

Hegel, Georg Wilhelm Friedrich. 1991. The Encyclopaedia Logic. Indianapolis, IN: Hackett.

Hesmondhalgh, David. 2013. The Cultural Industries. London: Sage. Third edition.

Hesmondhalgh, David and Sarah Baker. 2011. Creative Labour. Media Work in Three Cultural Industries. London: Routledge. 
Hofkirchner, Wolfgang. 2013. Emergent Information. A Unified Theory of Information Framework. Singapore: World Scientific.

Huws, Ursula. 1999. Material World. The Myth of the Weightless Economy. Socialist Register 35: 2955.

Huws, Ursula. 2008. Break or Weld? Trade Union Responses to Global Value Chain Restructuring. Work Organisation, Labour and Globalisation 2 (1): 1-10.

Huws, Ursula and Simone Dahlmann. 2010. Global Restructuring of Value Chains and Class Issues. In Interrogating the New Economy. Restructuring Work in the 21st Century, edited by Norene J. Pupo and Mark P. Thomas, 65-91. Toronto: University of Toronto Press.

Machlup, Fritz. 1962. The Production and Distribution of Knowledge in the United States. Princeton: Princeton University Press.

Marx, Karl. 1857/58. Grundrisse. London: Penguin.

Marx, Karl. 1867. Capital Vol I. London: Penguin.

Marx Karl 1885/1992. Capital Vol II. London: Penguin.

Marx, Karl and Friedrich Engels. 1845/46. The German Ideology. Amherst: Prometheus Books.

Maxwell, Richard and Toby Miller. 2012. Greening the Media. Oxford: Oxford University Press.

Miller, Toby, Nitin Govil, John McMurria, Richard Maxwell and Ting Wang. 2004. Global Hollywood 2. London: British Film Institute.

Mosco, Vincent and Catherine McKercher. 2009. The Laboring of Communication. Will Knowledge Workers of the World Unite? Lanham, MD: Lexington Books.

Noam, Eli. 2009. Media Ownership and Concentration in America. Oxford: Oxford University Press.

Porter, Michael. 1985. Competitive Advantage. Creating and Sustaining Superior Performance. New York: Free Press.

Sandoval, Marisol. 2013. Foxconned Labour as the Dark Side of the Information Age: Working Conditions at Apple's Contract Manufacturers in China. tripleC: Communication, Capitalism \& Critique 11 (2): 318-347.

Sandoval, Marisol. 2014. From Corporate to Social Media. Critical Perspectives on Corporate Social Responsibility in Media and Communication Industries. New York: Routledge.

Schmiede, Rudi. 1996. Informatisierung und gesellschaftliche Arbeit - Strukturveränderungen von Arbeit und Gesellschaft. In Virtuelle Arbeitswelten. Arbeit, Produktion und Subjekt in der „Informationsgesellschaft", 107-128. Berlin: edition sigma.

Scholz, Trebor, ed. 2013. Digital Labor. The Internet as Playground and Factory. New York: Routledge.

Students \& Scholars against Corporate Misbehaviour (SACOM). 2010. Workers as Machines: Military Management in Foxconn. Accessed August 9, 2013. http://sacom.hk/wpcontent/uploads/2010/11/reporton-foxconn-workers-as-machines sacom.pdf

Pellow, David N. and Lisa Sun-Hee Park. 2002. The Silicon Valley of Dreams: Environmental Injustice, Immigrant Workers, and the High-Tech Global Economy. NewYork: NewYork University Press.

Thompson, Edward P. 1978. The Poverty of Theory and Other Essays. New York: Monthly Review Press.

Toffler, Alvin. 1980. The Third Wave. New York: Bantam.

Weingart, Brigitte. 1997. Arbeit - ein Wort mit langer Geschichte. Accessed November 10, 2013. http://www.ethikprojekte.ch/texte/arbeit.htm

Williams, Raymond. 1958. Culture \& Society, 1780-1950. New York: Columbia University Press.

Williams, Raymond. 1962. Communications. Harmondsworth: Penguin.

Williams, Raymond. 1977. Marxism and Literature. Oxford: Oxford University Press.

Williams, Raymond. 1981. The Sociology of Culture. Chicago, IL: University of Chicago Press.

Williams, Raymond. 1983. Keywords. New York: Oxford University Press.

Williams, Raymond. 1989. What I Came to Say. London: Hutchinson Radius.

Zerdick, Axel et al. 2000. E-conomics. Strategies for the Digital Marketplace. Berlin: Springer.

\section{About the Authors}

Christian Fuchs

Christian Fuchs is professor of social media at the University of Westminster and co-editor of tripleC:

Communication, Capitalism \& Critique. http://fuchs.uti.at. 
Marisol Sandoval

Marisol Sandoval is a lecturer at City University London's Department of Culture and Creative Industries and co-editor of tripleC: Communication, Capitalism \& Critique. 
Annex A: 1728 Logically Possible Forms of Digital Information Labour

\begin{tabular}{|c|c|c|c|c|c|c|c|c|}
\hline$\#$ & $\begin{array}{l}\text { Information } \\
\text { worker }\end{array}$ & $\begin{array}{l}\text { Employer, } \\
\text { contractor }\end{array}$ & $\begin{array}{l}\text { Relationship } \\
\text { of production }\end{array}$ & Technology & Objects & Products & $\begin{array}{l}\text { Distri- } \\
\text { bution }\end{array}$ & $\begin{array}{l}\text { Con- } \\
\text { sumption }\end{array}$ \\
\hline 1 & Online & Online & Online & Brain + digital & Digital & Digital & Online & Online \\
\hline 2 & Online & Online & Online & Brain + digital & Digital & Digital & Online & Offline \\
\hline 3 & Online & Online & Online & Brain + digital & Digital & Digital & Offline & Online \\
\hline 4 & Online & Online & Online & Brain + digital & Digital & Digital & Offline & Offline \\
\hline 5 & Online & Online & Online & Brain + digital & Digital & Non-digital & Online & Online \\
\hline 6 & Online & Online & Online & Brain + digital & Digital & Non-digital & Online & Offline \\
\hline 7 & Online & Online & Online & Brain + digital & Digital & Non-digital & Offline & Online \\
\hline 8 & Online & Online & Online & Brain + digital & Digital & Non-digital & Offline & Offline \\
\hline 9 & Online & Online & Online & Brain + digital & Digital & Blended & Online & Online \\
\hline 10 & Online & Online & Online & Brain + digital & Digital & Blended & Online & Offline \\
\hline 11 & Online & Online & Online & Brain + digital & Digital & Blended & Offline & Online \\
\hline 12 & Online & Online & Online & Brain + digital & Digital & Blended & Offline & Offline \\
\hline 13 & Online & Online & Online & Brain + digital & $\begin{array}{l}\text { Non- } \\
\text { digital }\end{array}$ & Digital & Online & Online \\
\hline 14 & Online & Online & Online & Brain + digital & $\begin{array}{l}\text { Non- } \\
\text { digital }\end{array}$ & Digital & Online & Offline \\
\hline 15 & Online & Online & Online & Brain + digital & $\begin{array}{l}\text { Non- } \\
\text { digital }\end{array}$ & Digital & Offline & Online \\
\hline 16 & Online & Online & Online & Brain + digital & $\begin{array}{l}\text { Non- } \\
\text { digital }\end{array}$ & Digital & Offline & Offline \\
\hline 17 & Online & Online & Online & Brain + digital & $\begin{array}{l}\text { Non- } \\
\text { digital }\end{array}$ & Non-digital & Online & Online \\
\hline 18 & Online & Online & Online & Brain + digital & $\begin{array}{l}\text { Non- } \\
\text { digital }\end{array}$ & Non-digital & Online & Offline \\
\hline 19 & Online & Online & Online & Brain + digital & $\begin{array}{l}\text { Non- } \\
\text { digital }\end{array}$ & Non-digital & Offline & Online \\
\hline 20 & Online & Online & Online & Brain + digital & $\begin{array}{l}\text { Non- } \\
\text { digital }\end{array}$ & Non-digital & Offline & Offline \\
\hline 21 & Online & Online & Online & Brain + digital & $\begin{array}{l}\text { Non- } \\
\text { digital }\end{array}$ & Blended & Online & Online \\
\hline 22 & Online & Online & Online & Brain + digital & $\begin{array}{l}\text { Non- } \\
\text { digital }\end{array}$ & Blended & Online & Offline \\
\hline 23 & Online & Online & Online & Brain + digital & $\begin{array}{l}\text { Non- } \\
\text { digital }\end{array}$ & Blended & Offline & Online \\
\hline 24 & Online & Online & Online & Brain + digital & $\begin{array}{l}\text { Non- } \\
\text { digital }\end{array}$ & Blended & Offline & Offline \\
\hline 25 & Online & Online & Online & Brain + digital & $\begin{array}{l}\text { Blend- } \\
\text { ed }\end{array}$ & Digital & Online & Online \\
\hline 26 & Online & Online & Online & Brain + digital & $\begin{array}{l}\text { Blend- } \\
\text { ed }\end{array}$ & Digital & Online & Offline \\
\hline 27 & Online & Online & Online & Brain + digital & $\begin{array}{l}\text { Blend- } \\
\text { ed }\end{array}$ & Digital & Offline & Online \\
\hline 28 & Online & Online & Online & Brain + digital & $\begin{array}{l}\text { Blend- } \\
\text { ed }\end{array}$ & Digital & Offline & Offline \\
\hline 29 & Online & Online & Online & Brain + digital & $\begin{array}{l}\text { Blend- } \\
\text { ed }\end{array}$ & Non-digital & Online & Online \\
\hline 30 & Online & Online & Online & Brain + digital & $\begin{array}{l}\text { Blend- } \\
\text { ed }\end{array}$ & Non-digital & Online & Offline \\
\hline 31 & Online & Online & Online & Brain + digital & $\begin{array}{l}\text { Blend- } \\
\text { ed }\end{array}$ & Non-digital & Offline & Online \\
\hline 32 & Online & Online & Online & Brain + digital & $\begin{array}{l}\text { Blend- } \\
\text { ed }\end{array}$ & Non-digital & Offline & Offline \\
\hline 33 & Online & Online & Online & Brain + digital & $\begin{array}{l}\text { Blend- } \\
\text { ed }\end{array}$ & Blended & Online & Online \\
\hline 34 & Online & Online & Online & Brain + digital & $\begin{array}{l}\text { Blend- } \\
\text { ed }\end{array}$ & Blended & Online & Offline \\
\hline 35 & Online & Online & Online & Brain + digital & $\begin{array}{l}\text { Blend- } \\
\text { ed }\end{array}$ & Blended & Offline & Online \\
\hline 36 & Online & Online & Online & Brain + digital & $\begin{array}{l}\text { Blend- } \\
\text { ed }\end{array}$ & Blended & Offline & Offline \\
\hline 37 & Online & Online & Online & Brain & Digital & Digital & Online & Online \\
\hline
\end{tabular}




\begin{tabular}{|c|c|c|c|c|c|c|c|c|}
\hline 38 & Online & Online & Online & Brain & Digital & Digital & Online & Offline \\
\hline 39 & Online & Online & Online & Brain & Digital & Digital & Offline & Online \\
\hline 40 & Online & Online & Online & Brain & Digital & Digital & Offline & Offline \\
\hline 41 & Online & Online & Online & Brain & Digital & Non-digital & Online & Online \\
\hline 42 & Online & Online & Online & Brain & Digital & Non-digital & Online & Offline \\
\hline 43 & Online & Online & Online & Brain & Digital & Non-digital & Offline & Online \\
\hline 44 & Online & Online & Online & Brain & Digital & Non-digital & Offline & Offline \\
\hline 45 & Online & Online & Online & Brain & Digital & Blended & Online & Online \\
\hline 46 & Online & Online & Online & Brain & Digital & Blended & Online & Offline \\
\hline 47 & Online & Online & Online & Brain & Digital & Blended & Offline & Online \\
\hline 48 & Online & Online & Online & Brain & Digital & Blended & Offline & Offline \\
\hline 49 & Online & Online & Online & Brain & $\begin{array}{l}\text { Non- } \\
\text { digital }\end{array}$ & Digital & Online & Online \\
\hline 50 & Online & Online & Online & Brain & $\begin{array}{l}\text { Non- } \\
\text { digital }\end{array}$ & Digital & Online & Offline \\
\hline 51 & Online & Online & Online & Brain & $\begin{array}{l}\text { Non- } \\
\text { digital }\end{array}$ & Digital & Offline & Online \\
\hline 52 & Online & Online & Online & Brain & $\begin{array}{l}\text { Non- } \\
\text { digital }\end{array}$ & Digital & Offline & Offline \\
\hline 53 & Online & Online & Online & Brain & $\begin{array}{l}\text { Non- } \\
\text { digital }\end{array}$ & Non-digital & Online & Online \\
\hline 54 & Online & Online & Online & Brain & $\begin{array}{l}\text { Non- } \\
\text { digital }\end{array}$ & Non-digital & Online & Offline \\
\hline 55 & Online & Online & Online & Brain & $\begin{array}{l}\text { Non- } \\
\text { digital }\end{array}$ & Non-digital & Offline & Online \\
\hline 56 & Online & Online & Online & Brain & $\begin{array}{l}\text { Non- } \\
\text { digital }\end{array}$ & Non-digital & Offline & Offline \\
\hline 57 & Online & Online & Online & Brain & $\begin{array}{l}\text { Non- } \\
\text { digital }\end{array}$ & Blended & Online & Online \\
\hline 58 & Online & Online & Online & Brain & $\begin{array}{l}\text { Non- } \\
\text { digital }\end{array}$ & Blended & Online & Offline \\
\hline 59 & Online & Online & Online & Brain & $\begin{array}{l}\text { Non- } \\
\text { digital }\end{array}$ & Blended & Offline & Online \\
\hline 60 & Online & Online & Online & Brain & $\begin{array}{l}\text { Non- } \\
\text { digital }\end{array}$ & Blended & Offline & Offline \\
\hline 61 & Online & Online & Online & Brain & $\begin{array}{l}\text { Blend- } \\
\text { ed }\end{array}$ & Digital & Online & Online \\
\hline 62 & Online & Online & Online & Brain & $\begin{array}{l}\text { Blend- } \\
\text { ed }\end{array}$ & Digital & Online & Offline \\
\hline 63 & Online & Online & Online & Brain & $\begin{array}{l}\text { Blend- } \\
\text { ed }\end{array}$ & Digital & Offline & Online \\
\hline 64 & Online & Online & Online & Brain & $\begin{array}{l}\text { Blend- } \\
\text { ed }\end{array}$ & Digital & Offline & Offline \\
\hline 65 & Online & Online & Online & Brain & $\begin{array}{l}\text { Blend- } \\
\text { ed }\end{array}$ & Non-digital & Online & Online \\
\hline 66 & Online & Online & Online & Brain & $\begin{array}{l}\text { Blend- } \\
\text { ed }\end{array}$ & Non-digital & Online & Offline \\
\hline 67 & Online & Online & Online & Brain & $\begin{array}{l}\text { Blend- } \\
\text { ed }\end{array}$ & Non-digital & Offline & Online \\
\hline 68 & Online & Online & Online & Brain & $\begin{array}{l}\text { Blend- } \\
\text { ed }\end{array}$ & Non-digital & Offline & Offline \\
\hline 69 & Online & Online & Online & Brain & $\begin{array}{l}\text { Blend- } \\
\text { ed }\end{array}$ & Blended & Online & Online \\
\hline 70 & Online & Online & Online & Brain & $\begin{array}{l}\text { Blend- } \\
\text { ed }\end{array}$ & Blended & Online & Offline \\
\hline 71 & Online & Online & Online & Brain & $\begin{array}{l}\text { Blend- } \\
\text { ed }\end{array}$ & Blended & Offline & Online \\
\hline 72 & Online & Online & Online & Brain & $\begin{array}{l}\text { Blend- } \\
\text { ed }\end{array}$ & Blended & Offline & Offline \\
\hline 73 & Online & Online & Online & Brain $+d+n-d$ & Digital & Digital & Online & Online \\
\hline 74 & Online & Online & Online & Brain $+d+n-d$ & Digital & Digital & Online & Offline \\
\hline 75 & Online & Online & Online & Brain $+d+n-d$ & Digital & Digital & Offline & Online \\
\hline 76 & Online & Online & Online & Brain $+d+n-d$ & Digital & Digital & Offline & Offline \\
\hline 77 & Online & Online & Online & Brain $+d+n-d$ & Digital & Non-digital & Online & Online \\
\hline 78 & Online & Online & Online & Brain $+d+n-d$ & Digital & Non-digital & Online & Offline \\
\hline
\end{tabular}




\begin{tabular}{|c|c|c|c|c|c|c|c|c|}
\hline 79 & Online & Online & Online & Brain $+d+n-d$ & Digital & Non-digital & Offline & Online \\
\hline 80 & Online & Online & Online & Brain $+d+n-d$ & Digital & Non-digital & Offline & Offline \\
\hline 81 & Online & Online & Online & Brain $+d+n-d$ & Digital & Blended & Online & Online \\
\hline 82 & Online & Online & Online & Brain $+d+n-d$ & Digital & Blended & Online & Offline \\
\hline 83 & Online & Online & Online & Brain $+d+n-d$ & Digital & Blended & Offline & Online \\
\hline 84 & Online & Online & Online & Brain $+d+n-d$ & Digital & Blended & Offline & Offline \\
\hline 85 & Online & Online & Online & Brain $+d+n-d$ & $\begin{array}{l}\text { Non- } \\
\text { digital }\end{array}$ & Digital & Online & Online \\
\hline 86 & Online & Online & Online & Brain $+d+n-d$ & $\begin{array}{l}\text { Non- } \\
\text { digital }\end{array}$ & Digital & Online & Offline \\
\hline 87 & Online & Online & Online & Brain $+d+n-d$ & $\begin{array}{l}\text { Non- } \\
\text { digital }\end{array}$ & Digital & Offline & Online \\
\hline 88 & Online & Online & Online & Brain $+d+n-d$ & $\begin{array}{l}\text { Non- } \\
\text { digital }\end{array}$ & Digital & Offline & Offline \\
\hline 89 & Online & Online & Online & Brain $+d+n-d$ & $\begin{array}{l}\text { Non- } \\
\text { digital }\end{array}$ & Non-digital & Online & Online \\
\hline 90 & Online & Online & Online & Brain $+d+n-d$ & $\begin{array}{l}\text { Non- } \\
\text { digital }\end{array}$ & Non-digital & Online & Offline \\
\hline 91 & Online & Online & Online & Brain $+d+n-d$ & $\begin{array}{l}\text { Non- } \\
\text { digital }\end{array}$ & Non-digital & Offline & Online \\
\hline 92 & Online & Online & Online & Brain $+d+n-d$ & $\begin{array}{l}\text { Non- } \\
\text { digital }\end{array}$ & Non-digital & Offline & Offline \\
\hline 93 & Online & Online & Online & Brain $+d+n-d$ & $\begin{array}{l}\text { Non- } \\
\text { digital }\end{array}$ & Blended & Online & Online \\
\hline 94 & Online & Online & Online & Brain $+d+n-d$ & $\begin{array}{l}\text { Non- } \\
\text { digital }\end{array}$ & Blended & Online & Offline \\
\hline 95 & Online & Online & Online & Brain $+d+n-d$ & $\begin{array}{l}\text { Non- } \\
\text { digital }\end{array}$ & Blended & Offline & Online \\
\hline 96 & Online & Online & Online & Brain $+d+n-d$ & $\begin{array}{l}\text { Non- } \\
\text { digital }\end{array}$ & Blended & Offline & Offline \\
\hline 97 & Online & Online & Online & Brain $+d+n-d$ & $\begin{array}{l}\text { Blend- } \\
\text { ed }\end{array}$ & Digital & Online & Online \\
\hline 98 & Online & Online & Online & Brain $+d+n-d$ & $\begin{array}{l}\text { Blend- } \\
\text { ed }\end{array}$ & Digital & Online & Offline \\
\hline 99 & Online & Online & Online & Brain $+d+n-d$ & $\begin{array}{l}\text { Blend- } \\
\text { ed }\end{array}$ & Digital & Offline & Online \\
\hline 100 & Online & Online & Online & Brain $+d+n-d$ & $\begin{array}{l}\text { Blend- } \\
\text { ed }\end{array}$ & Digital & Offline & Offline \\
\hline 101 & Online & Online & Online & Brain $+d+n-d$ & $\begin{array}{l}\text { Blend- } \\
\text { ed }\end{array}$ & Non-digital & Online & Online \\
\hline 102 & Online & Online & Online & Brain $+d+n-d$ & $\begin{array}{l}\text { Blend- } \\
\text { ed }\end{array}$ & Non-digital & Online & Offline \\
\hline 103 & Online & Online & Online & Brain $+d+n-d$ & $\begin{array}{l}\text { Blend- } \\
\text { ed }\end{array}$ & Non-digital & Offline & Online \\
\hline 104 & Online & Online & Online & Brain $+d+n-d$ & $\begin{array}{l}\text { Blend- } \\
\text { ed }\end{array}$ & Non-digital & Offline & Offline \\
\hline 105 & Online & Online & Online & Brain $+d+n-d$ & $\begin{array}{l}\text { Blend- } \\
\text { ed }\end{array}$ & Blended & Online & Online \\
\hline 106 & Online & Online & Online & Brain $+d+n-d$ & $\begin{array}{l}\text { Blend- } \\
\text { ed }\end{array}$ & Blended & Online & Offline \\
\hline 107 & Online & Online & Online & Brain $+d+n-d$ & $\begin{array}{l}\text { Blend- } \\
\text { ed }\end{array}$ & Blended & Offline & Online \\
\hline 108 & Online & Online & Online & Brain $+d+n-d$ & $\begin{array}{l}\text { Blend- } \\
\text { ed }\end{array}$ & Blended & Offline & Offline \\
\hline 109 & Online & Online & Online & Brain + n-d & Digital & Digital & Online & Online \\
\hline 110 & Online & Online & Online & Brain + n-d & Digital & Digital & Online & Offline \\
\hline 111 & Online & Online & Online & Brain + n-d & Digital & Digital & Offline & Online \\
\hline 112 & Online & Online & Online & Brain + n-d & Digital & Digital & Offline & Offline \\
\hline 113 & Online & Online & Online & Brain + n-d & Digital & Non-digital & Online & Online \\
\hline 114 & Online & Online & Online & Brain + n-d & Digital & Non-digital & Online & Offline \\
\hline 115 & Online & Online & Online & Brain + n-d & Digital & Non-digital & Offline & Online \\
\hline 116 & Online & Online & Online & Brain + n-d & Digital & Non-digital & Offline & Offline \\
\hline 117 & Online & Online & Online & Brain + n-d & Digital & Blended & Online & Online \\
\hline 118 & Online & Online & Online & Brain + n-d & Digital & Blended & Online & Offline \\
\hline 119 & Online & Online & Online & Brain $+n-d$ & Digital & Blended & Offline & Online \\
\hline
\end{tabular}




\begin{tabular}{|c|c|c|c|c|c|c|c|c|}
\hline 120 & Online & Online & Online & Brain + n-d & Digital & Blended & Offline & Offline \\
\hline 121 & Online & Online & Online & Brain + n-d & $\begin{array}{l}\text { Non- } \\
\text { digital }\end{array}$ & Digital & Online & Online \\
\hline 122 & Online & Online & Online & Brain + n-d & $\begin{array}{l}\text { Non- } \\
\text { digital }\end{array}$ & Digital & Online & Offline \\
\hline 123 & Online & Online & Online & Brain + n-d & $\begin{array}{l}\text { Non- } \\
\text { digital }\end{array}$ & Digital & Offline & Online \\
\hline 124 & Online & Online & Online & Brain + n-d & $\begin{array}{l}\text { Non- } \\
\text { digital }\end{array}$ & Digital & Offline & Offline \\
\hline 125 & Online & Online & Online & Brain + n-d & $\begin{array}{l}\text { Non- } \\
\text { digital }\end{array}$ & Non-digital & Online & Online \\
\hline 126 & Online & Online & Online & Brain + n-d & $\begin{array}{l}\text { Non- } \\
\text { digital }\end{array}$ & Non-digital & Online & Offline \\
\hline 127 & Online & Online & Online & Brain + n-d & $\begin{array}{l}\text { Non- } \\
\text { digital }\end{array}$ & Non-digital & Offline & Online \\
\hline 128 & Online & Online & Online & Brain $+n-d$ & $\begin{array}{l}\text { Non- } \\
\text { digital }\end{array}$ & Non-digital & Offline & Offline \\
\hline 129 & Online & Online & Online & Brain + n-d & $\begin{array}{l}\text { Non- } \\
\text { digital }\end{array}$ & Blended & Online & Online \\
\hline 130 & Online & Online & Online & Brain + n-d & $\begin{array}{l}\text { Non- } \\
\text { digital }\end{array}$ & Blended & Online & Offline \\
\hline 131 & Online & Online & Online & Brain + n-d & $\begin{array}{l}\text { Non- } \\
\text { digital }\end{array}$ & Blended & Offline & Online \\
\hline 132 & Online & Online & Online & Brain $+n-d$ & $\begin{array}{l}\text { Non- } \\
\text { digital }\end{array}$ & Blended & Offline & Offline \\
\hline 133 & Online & Online & Online & Brain + n-d & $\begin{array}{l}\text { Blend- } \\
\text { ed }\end{array}$ & Digital & Online & Online \\
\hline 134 & Online & Online & Online & Brain + n-d & $\begin{array}{l}\text { Blend- } \\
\text { ed }\end{array}$ & Digital & Online & Offline \\
\hline 135 & Online & Online & Online & Brain + n-d & $\begin{array}{l}\text { Blend- } \\
\text { ed }\end{array}$ & Digital & Offline & Online \\
\hline 136 & Online & Online & Online & Brain $+n-d$ & $\begin{array}{l}\text { Blend- } \\
\text { ed }\end{array}$ & Digital & Offline & Offline \\
\hline 137 & Online & Online & Online & Brain + n-d & $\begin{array}{l}\text { Blend- } \\
\text { ed }\end{array}$ & Non-digital & Online & Online \\
\hline 138 & Online & Online & Online & Brain + n-d & $\begin{array}{l}\text { Blend- } \\
\text { ed }\end{array}$ & Non-digital & Online & Offline \\
\hline 139 & Online & Online & Online & Brain + n-d & $\begin{array}{l}\text { Blend- } \\
\text { ed }\end{array}$ & Non-digital & Offline & Online \\
\hline 140 & Online & Online & Online & Brain + n-d & $\begin{array}{l}\text { Blend- } \\
\text { ed }\end{array}$ & Non-digital & Offline & Offline \\
\hline 141 & Online & Online & Online & Brain + n-d & $\begin{array}{l}\text { Blend- } \\
\text { ed }\end{array}$ & Blended & Online & Online \\
\hline 142 & Online & Online & Online & Brain + n-d & $\begin{array}{l}\text { Blend- } \\
\text { ed }\end{array}$ & Blended & Online & Offline \\
\hline 143 & Online & Online & Online & Brain + n-d & $\begin{array}{l}\text { Blend- } \\
\text { ed }\end{array}$ & Blended & Offline & Online \\
\hline 144 & Online & Online & Online & Brain + n-d & $\begin{array}{l}\text { Blend- } \\
\text { ed }\end{array}$ & Blended & Offline & Offline \\
\hline 145 & Online & Online & Offline & Brain + digital & Digital & Digital & Online & Online \\
\hline 146 & Online & Online & Offline & Brain + digital & Digital & Digital & Online & Offline \\
\hline 147 & Online & Online & Offline & Brain + digital & Digital & Digital & Offline & Online \\
\hline 148 & Online & Online & Offline & Brain + digital & Digital & Digital & Offline & Offline \\
\hline 149 & Online & Online & Offline & Brain + digital & Digital & Non-digital & Online & Online \\
\hline 150 & Online & Online & Offline & Brain + digital & Digital & Non-digital & Online & Offline \\
\hline 151 & Online & Online & Offline & Brain + digital & Digital & Non-digital & Offline & Online \\
\hline 152 & Online & Online & Offline & Brain + digital & Digital & Non-digital & Offline & Offline \\
\hline 153 & Online & Online & Offline & Brain + digital & Digital & Blended & Online & Online \\
\hline 154 & Online & Online & Offline & Brain + digital & Digital & Blended & Online & Offline \\
\hline 155 & Online & Online & Offline & Brain + digital & Digital & Blended & Offline & Online \\
\hline 156 & Online & Online & Offline & Brain + digital & Digital & Blended & Offline & Offline \\
\hline 157 & Online & Online & Offline & Brain + digital & $\begin{array}{l}\text { Non- } \\
\text { digital }\end{array}$ & Digital & Online & Online \\
\hline 158 & Online & Online & Offline & Brain + digital & $\begin{array}{l}\text { Non- } \\
\text { digital }\end{array}$ & Digital & Online & Offline \\
\hline
\end{tabular}




\begin{tabular}{|c|c|c|c|c|c|c|c|c|}
\hline 159 & Online & Online & Offline & Brain + digital & $\begin{array}{l}\text { Non- } \\
\text { digital }\end{array}$ & Digital & Offline & Online \\
\hline 160 & Online & Online & Offline & Brain + digital & $\begin{array}{l}\text { Non- } \\
\text { digital }\end{array}$ & Digital & Offline & Offline \\
\hline 161 & Online & Online & Offline & Brain + digital & $\begin{array}{l}\text { Non- } \\
\text { digital }\end{array}$ & Non-digital & Online & Online \\
\hline 162 & Online & Online & Offline & Brain + digital & $\begin{array}{l}\text { Non- } \\
\text { digital }\end{array}$ & Non-digital & Online & Offline \\
\hline 163 & Online & Online & Offline & Brain + digital & $\begin{array}{l}\text { Non- } \\
\text { digital }\end{array}$ & Non-digital & Offline & Online \\
\hline 164 & Online & Online & Offline & Brain + digital & $\begin{array}{l}\text { Non- } \\
\text { digital }\end{array}$ & Non-digital & Offline & Offline \\
\hline 165 & Online & Online & Offline & Brain + digital & $\begin{array}{l}\text { Non- } \\
\text { digital }\end{array}$ & Blended & Online & Online \\
\hline 166 & Online & Online & Offline & Brain + digital & $\begin{array}{l}\text { Non- } \\
\text { digital }\end{array}$ & Blended & Online & Offline \\
\hline 167 & Online & Online & Offline & Brain + digital & $\begin{array}{l}\text { Non- } \\
\text { digital }\end{array}$ & Blended & Offline & Online \\
\hline 168 & Online & Online & Offline & Brain + digital & $\begin{array}{l}\text { Non- } \\
\text { digital }\end{array}$ & Blended & Offline & Offline \\
\hline 169 & Online & Online & Offline & Brain + digital & $\begin{array}{l}\text { Blend- } \\
\text { ed }\end{array}$ & Digital & Online & Online \\
\hline 170 & Online & Online & Offline & Brain + digital & $\begin{array}{l}\text { Blend- } \\
\text { ed }\end{array}$ & Digital & Online & Offline \\
\hline 171 & Online & Online & Offline & Brain + digital & $\begin{array}{l}\text { Blend- } \\
\text { ed }\end{array}$ & Digital & Offline & Online \\
\hline 172 & Online & Online & Offline & Brain + digital & $\begin{array}{l}\text { Blend- } \\
\text { ed }\end{array}$ & Digital & Offline & Offline \\
\hline 173 & Online & Online & Offline & Brain + digital & $\begin{array}{l}\text { Blend- } \\
\text { ed }\end{array}$ & Non-digital & Online & Online \\
\hline 174 & Online & Online & Offline & Brain + digital & $\begin{array}{l}\text { Blend- } \\
\text { ed }\end{array}$ & Non-digital & Online & Offline \\
\hline 175 & Online & Online & Offline & Brain + digital & $\begin{array}{l}\text { Blend- } \\
\text { ed }\end{array}$ & Non-digital & Offline & Online \\
\hline 176 & Online & Online & Offline & Brain + digital & $\begin{array}{l}\text { Blend- } \\
\text { ed }\end{array}$ & Non-digital & Offline & Offline \\
\hline 177 & Online & Online & Offline & Brain + digital & $\begin{array}{l}\text { Blend- } \\
\text { ed }\end{array}$ & Blended & Online & Online \\
\hline 178 & Online & Online & Offline & Brain + digital & $\begin{array}{l}\text { Blend- } \\
\text { ed }\end{array}$ & Blended & Online & Offline \\
\hline 179 & Online & Online & Offline & Brain + digital & $\begin{array}{l}\text { Blend- } \\
\text { ed }\end{array}$ & Blended & Offline & Online \\
\hline 180 & Online & Online & Offline & Brain + digital & $\begin{array}{l}\text { Blend- } \\
\text { ed }\end{array}$ & Blended & Offline & Offline \\
\hline 181 & Online & Online & Offline & Brain & Digital & Digital & Online & Online \\
\hline 182 & Online & Online & Offline & Brain & Digital & Digital & Online & Offline \\
\hline 183 & Online & Online & Offline & Brain & Digital & Digital & Offline & Online \\
\hline 184 & Online & \begin{tabular}{|l|} 
Online \\
\end{tabular} & Offline & Brain & Digital & Digital & Offline & Offline \\
\hline 185 & Online & Online & Offline & Brain & Digital & Non-digital & Online & Online \\
\hline 186 & Online & Online & Offline & Brain & Digital & Non-digital & Online & Offline \\
\hline 187 & Online & Online & Offline & Brain & Digital & Non-digital & Offline & Online \\
\hline 188 & Online & Online & Offline & Brain & Digital & Non-digital & Offline & Offline \\
\hline 189 & Online & Online & Offline & Brain & Digital & Blended & Online & Online \\
\hline 190 & Online & Online & Offline & Brain & Digital & Blended & Online & Offline \\
\hline 191 & Online & Online & Offline & Brain & Digital & Blended & Offline & Online \\
\hline 192 & Online & Online & Offline & Brain & Digital & Blended & Offline & Offline \\
\hline 193 & Online & Online & Offline & Brain & $\begin{array}{l}\text { Non- } \\
\text { digital }\end{array}$ & Digital & Online & Online \\
\hline 194 & Online & Online & Offline & Brain & $\begin{array}{l}\text { Non- } \\
\text { digital } \\
\end{array}$ & Digital & Online & Offline \\
\hline 195 & Online & Online & Offline & Brain & $\begin{array}{l}\text { Non- } \\
\text { digital }\end{array}$ & Digital & Offline & Online \\
\hline 196 & Online & Online & Offline & Brain & $\begin{array}{l}\text { Non- } \\
\text { digital }\end{array}$ & Digital & Offline & Offline \\
\hline
\end{tabular}




\begin{tabular}{|c|c|c|c|c|c|c|c|c|}
\hline 197 & Online & Online & Offline & Brain & $\begin{array}{l}\text { Non- } \\
\text { digital }\end{array}$ & Non-digital & Online & Online \\
\hline 198 & Online & Online & Offline & Brain & $\begin{array}{l}\text { Non- } \\
\text { digital }\end{array}$ & Non-digital & Online & Offline \\
\hline 199 & Online & Online & Offline & Brain & $\begin{array}{l}\text { Non- } \\
\text { digital }\end{array}$ & Non-digital & Offline & Online \\
\hline 200 & Online & Online & Offline & Brain & $\begin{array}{l}\text { Non- } \\
\text { digital }\end{array}$ & Non-digital & Offline & Offline \\
\hline 201 & Online & Online & Offline & Brain & $\begin{array}{l}\text { Non- } \\
\text { digital }\end{array}$ & Blended & Online & Online \\
\hline 202 & Online & Online & Offline & Brain & $\begin{array}{l}\text { Non- } \\
\text { digital }\end{array}$ & Blended & Online & Offline \\
\hline 203 & Online & Online & Offline & Brain & $\begin{array}{l}\text { Non- } \\
\text { digital }\end{array}$ & Blended & Offline & Online \\
\hline 204 & Online & Online & Offline & Brain & $\begin{array}{l}\text { Non- } \\
\text { digital }\end{array}$ & Blended & Offline & Offline \\
\hline 205 & Online & Online & Offline & Brain & $\begin{array}{l}\text { Blend- } \\
\text { ed }\end{array}$ & Digital & Online & Online \\
\hline 206 & Online & Online & Offline & Brain & $\begin{array}{l}\text { Blend- } \\
\text { ed }\end{array}$ & Digital & Online & Offline \\
\hline 207 & Online & Online & Offline & Brain & $\begin{array}{l}\text { Blend- } \\
\text { ed }\end{array}$ & Digital & Offline & Online \\
\hline 208 & Online & Online & Offline & Brain & $\begin{array}{l}\text { Blend- } \\
\text { ed }\end{array}$ & Digital & Offline & Offline \\
\hline 209 & Online & Online & Offline & Brain & $\begin{array}{l}\text { Blend- } \\
\text { ed }\end{array}$ & Non-digital & Online & Online \\
\hline 210 & Online & Online & Offline & Brain & $\begin{array}{l}\text { Blend- } \\
\text { ed }\end{array}$ & Non-digital & Online & Offline \\
\hline 211 & Online & Online & Offline & Brain & $\begin{array}{l}\text { Blend- } \\
\text { ed }\end{array}$ & Non-digital & Offline & Online \\
\hline 212 & Online & Online & Offline & Brain & $\begin{array}{l}\text { Blend- } \\
\text { ed }\end{array}$ & Non-digital & Offline & Offline \\
\hline 213 & Online & Online & Offline & Brain & $\begin{array}{l}\text { Blend- } \\
\text { ed }\end{array}$ & Blended & Online & Online \\
\hline 214 & Online & Online & Offline & Brain & $\begin{array}{l}\text { Blend- } \\
\text { ed }\end{array}$ & Blended & Online & Offline \\
\hline 215 & Online & Online & Offline & Brain & $\begin{array}{l}\text { Blend- } \\
\text { ed }\end{array}$ & Blended & Offline & Online \\
\hline 216 & Online & Online & Offline & Brain & $\begin{array}{l}\text { Blend- } \\
\text { ed }\end{array}$ & Blended & Offline & Offline \\
\hline 217 & Online & Online & Offline & Brain $+d+n-d$ & Digital & Digital & Online & Online \\
\hline 218 & Online & Online & Offline & Brain $+d+n-d$ & Digital & Digital & Online & Offline \\
\hline 219 & Online & Online & Offline & Brain $+d+n-d$ & Digital & Digital & Offline & Online \\
\hline 220 & Online & Online & Offline & Brain $+d+n-d$ & Digital & Digital & Offline & Offline \\
\hline 221 & Online & Online & Offline & Brain $+d+n-d$ & Digital & Non-digital & Online & Online \\
\hline 222 & Online & Online & Offline & Brain $+d+n-d$ & Digital & Non-digital & Online & Offline \\
\hline 223 & Online & Online & Offline & Brain $+d+n-d$ & Digital & Non-digital & Offline & Online \\
\hline 224 & Online & Online & Offline & Brain $+d+n-d$ & Digital & Non-digital & Offline & Offline \\
\hline 225 & Online & Online & Offline & Brain $+d+n-d$ & Digital & Blended & Online & Online \\
\hline 226 & Online & Online & Offline & Brain $+d+n-d$ & Digital & Blended & Online & Offline \\
\hline 227 & Online & Online & Offline & Brain + d + n-d & Digital & Blended & Offline & Online \\
\hline 228 & Online & Online & Offline & Brain + d + n-d & Digital & Blended & Offline & Offline \\
\hline 229 & Online & Online & Offline & Brain $+d+n-d$ & $\begin{array}{l}\text { Non- } \\
\text { digital }\end{array}$ & Digital & Online & Online \\
\hline 230 & Online & Online & Offline & Brain $+d+n-d$ & $\begin{array}{l}\text { Non- } \\
\text { digital }\end{array}$ & Digital & Online & Offline \\
\hline 231 & Online & Online & Offline & Brain $+d+n-d$ & $\begin{array}{l}\text { Non- } \\
\text { digital }\end{array}$ & Digital & Offline & Online \\
\hline 232 & Online & Online & Offline & Brain $+d+n-d$ & $\begin{array}{l}\text { Non- } \\
\text { digital }\end{array}$ & Digital & Offline & Offline \\
\hline 233 & Online & Online & Offline & Brain $+d+n-d$ & $\begin{array}{l}\text { Non- } \\
\text { digital }\end{array}$ & Non-digital & Online & Online \\
\hline 234 & Online & Online & Offline & Brain $+d+n-d$ & $\begin{array}{l}\text { Non- } \\
\text { digital }\end{array}$ & Non-digital & Online & Offline \\
\hline
\end{tabular}




\begin{tabular}{|c|c|c|c|c|c|c|c|c|}
\hline 235 & Online & Online & Offline & Brain $+d+n-d$ & $\begin{array}{l}\text { Non- } \\
\text { digital }\end{array}$ & Non-digital & Offline & Online \\
\hline 236 & Online & Online & Offline & Brain $+d+n-d$ & $\begin{array}{l}\text { Non- } \\
\text { digital }\end{array}$ & Non-digital & Offline & Offline \\
\hline 237 & Online & Online & Offline & Brain $+d+n-d$ & $\begin{array}{l}\text { Non- } \\
\text { digital }\end{array}$ & Blended & Online & Online \\
\hline 238 & Online & Online & Offline & Brain $+d+n-d$ & $\begin{array}{l}\text { Non- } \\
\text { digital }\end{array}$ & Blended & Online & Offline \\
\hline 239 & Online & Online & Offline & Brain $+d+n-d$ & $\begin{array}{l}\text { Non- } \\
\text { digital }\end{array}$ & Blended & Offline & Online \\
\hline 240 & Online & Online & Offline & Brain $+d+n-d$ & $\begin{array}{l}\text { Non- } \\
\text { digital }\end{array}$ & Blended & Offline & Offline \\
\hline 241 & Online & Online & Offline & Brain $+d+n-d$ & $\begin{array}{l}\text { Blend- } \\
\text { ed }\end{array}$ & Digital & Online & Online \\
\hline 242 & Online & Online & Offline & Brain $+d+n-d$ & $\begin{array}{l}\text { Blend- } \\
\text { ed }\end{array}$ & Digital & Online & Offline \\
\hline 243 & Online & Online & Offline & Brain $+d+n-d$ & $\begin{array}{l}\text { Blend- } \\
\text { ed }\end{array}$ & Digital & Offline & Online \\
\hline 244 & Online & Online & Offline & Brain $+d+n-d$ & $\begin{array}{l}\text { Blend- } \\
\text { ed }\end{array}$ & Digital & Offline & Offline \\
\hline 245 & Online & Online & Offline & Brain $+d+n-d$ & $\begin{array}{l}\text { Blend- } \\
\text { ed }\end{array}$ & Non-digital & Online & Online \\
\hline 246 & Online & Online & Offline & Brain $+d+n-d$ & $\begin{array}{l}\text { Blend- } \\
\text { ed }\end{array}$ & Non-digital & Online & Offline \\
\hline 247 & Online & Online & Offline & Brain $+d+n-d$ & $\begin{array}{l}\text { Blend- } \\
\text { ed }\end{array}$ & Non-digital & Offline & Online \\
\hline 248 & Online & Online & Offline & Brain $+d+n-d$ & $\begin{array}{l}\text { Blend- } \\
\text { ed }\end{array}$ & Non-digital & Offline & Offline \\
\hline 249 & Online & Online & Offline & Brain $+d+n-d$ & $\begin{array}{l}\text { Blend- } \\
\text { ed }\end{array}$ & Blended & Online & Online \\
\hline 250 & Online & Online & Offline & Brain $+d+n-d$ & $\begin{array}{l}\text { Blend- } \\
\text { ed }\end{array}$ & Blended & Online & Offline \\
\hline 251 & Online & Online & Offline & Brain $+d+n-d$ & $\begin{array}{l}\text { Blend- } \\
\text { ed }\end{array}$ & Blended & Offline & Online \\
\hline 252 & Online & Online & Offline & Brain $+d+n-d$ & $\begin{array}{l}\text { Blend- } \\
\text { ed }\end{array}$ & Blended & Offline & Offline \\
\hline 253 & Online & Online & Offline & Brain $+n-d$ & Digital & Digital & Online & Online \\
\hline 254 & Online & Online & Offline & Brain $+n-d$ & Digital & Digital & Online & Offline \\
\hline 255 & Online & Online & Offline & Brain $+n-d$ & Digital & Digital & Offline & Online \\
\hline 256 & Online & Online & Offline & Brain $+n-d$ & Digital & Digital & Offline & Offline \\
\hline 257 & Online & Online & Offline & Brain + n-d & Digital & Non-digital & Online & Online \\
\hline 258 & Online & Online & Offline & Brain + n-d & Digital & Non-digital & Online & Offline \\
\hline 259 & Online & Online & Offline & Brain $+n-d$ & Digital & Non-digital & Offline & Online \\
\hline 260 & Online & Online & Offline & Brain $+n-d$ & Digital & Non-digital & Offline & Offline \\
\hline 261 & Online & Online & Offline & Brain + n-d & Digital & Blended & Online & Online \\
\hline 262 & Online & Online & Offline & Brain + n-d & Digital & Blended & Online & Offline \\
\hline 263 & Online & Online & Offline & Brain $+n-d$ & Digital & Blended & Offline & Online \\
\hline 264 & Online & Online & Offline & Brain $+n-d$ & Digital & Blended & Offline & Offline \\
\hline 265 & Online & Online & Offline & Brain + n-d & $\begin{array}{l}\text { Non- } \\
\text { digital }\end{array}$ & Digital & Online & Online \\
\hline 266 & Online & Online & Offline & Brain $+n-d$ & $\begin{array}{l}\text { Non- } \\
\text { digital }\end{array}$ & Digital & Online & Offline \\
\hline 267 & Online & Online & Offline & Brain $+n-d$ & $\begin{array}{l}\text { Non- } \\
\text { digital }\end{array}$ & Digital & Offline & Online \\
\hline 268 & Online & Online & Offline & Brain + n-d & $\begin{array}{l}\text { Non- } \\
\text { digital }\end{array}$ & Digital & Offline & Offline \\
\hline 269 & Online & Online & Offline & Brain + n-d & $\begin{array}{l}\text { Non- } \\
\text { digital }\end{array}$ & Non-digital & Online & Online \\
\hline 270 & Online & Online & Offline & Brain + n-d & $\begin{array}{l}\text { Non- } \\
\text { digital }\end{array}$ & Non-digital & Online & Offline \\
\hline 271 & Online & Online & Offline & Brain + n-d & $\begin{array}{l}\text { Non- } \\
\text { digital }\end{array}$ & Non-digital & Offline & Online \\
\hline 272 & Online & Online & Offline & Brain $+n-d$ & $\begin{array}{l}\text { Non- } \\
\text { digital }\end{array}$ & Non-digital & Offline & Offline \\
\hline
\end{tabular}




\begin{tabular}{|c|c|c|c|c|c|c|c|c|}
\hline 273 & Online & Online & Offline & Brain + n-d & $\begin{array}{l}\text { Non- } \\
\text { digital }\end{array}$ & Blended & Online & Online \\
\hline 274 & Online & Online & Offline & Brain + n-d & $\begin{array}{l}\text { Non- } \\
\text { digital }\end{array}$ & Blended & Online & Offline \\
\hline 275 & Online & Online & Offline & Brain + n-d & $\begin{array}{l}\text { Non- } \\
\text { digital }\end{array}$ & Blended & Offline & Online \\
\hline 276 & Online & Online & Offline & Brain + n-d & $\begin{array}{l}\text { Non- } \\
\text { digital }\end{array}$ & Blended & Offline & Offline \\
\hline 277 & Online & Online & Offline & Brain + n-d & $\begin{array}{l}\text { Blend- } \\
\text { ed }\end{array}$ & Digital & Online & Online \\
\hline 278 & Online & Online & Offline & Brain + n-d & $\begin{array}{l}\text { Blend- } \\
\text { ed }\end{array}$ & Digital & Online & Offline \\
\hline 279 & Online & Online & Offline & Brain + n-d & $\begin{array}{l}\text { Blend- } \\
\text { ed }\end{array}$ & Digital & Offline & Online \\
\hline 280 & Online & Online & Offline & Brain + n-d & $\begin{array}{l}\text { Blend- } \\
\text { ed }\end{array}$ & Digital & Offline & Offline \\
\hline 281 & Online & Online & Offline & Brain + n-d & $\begin{array}{l}\text { Blend- } \\
\text { ed }\end{array}$ & Non-digital & Online & Online \\
\hline 282 & Online & Online & Offline & Brain + n-d & $\begin{array}{l}\text { Blend- } \\
\text { ed }\end{array}$ & Non-digital & Online & Offline \\
\hline 283 & Online & Online & Offline & Brain + n-d & $\begin{array}{l}\text { Blend- } \\
\text { ed }\end{array}$ & Non-digital & Offline & Online \\
\hline 284 & Online & Online & Offline & Brain + n-d & $\begin{array}{l}\text { Blend- } \\
\text { ed }\end{array}$ & Non-digital & Offline & Offline \\
\hline 285 & Online & Online & Offline & Brain + n-d & $\begin{array}{l}\text { Blend- } \\
\text { ed }\end{array}$ & Blended & Online & Online \\
\hline 286 & Online & Online & Offline & Brain + n-d & $\begin{array}{l}\text { Blend- } \\
\text { ed }\end{array}$ & Blended & Online & Offline \\
\hline 287 & Online & Online & Offline & Brain + n-d & $\begin{array}{l}\text { Blend- } \\
\text { ed }\end{array}$ & Blended & Offline & Online \\
\hline 288 & Online & Online & Offline & Brain + n-d & $\begin{array}{l}\text { Blend- } \\
\text { ed }\end{array}$ & Blended & Offline & Offline \\
\hline 289 & Online & Online & Blended & Brain + digital & Digital & Digital & Online & Online \\
\hline 290 & Online & Online & Blended & Brain + digital & Digital & Digital & Online & Offline \\
\hline 291 & Online & Online & Blended & Brain + digital & Digital & Digital & Offline & Online \\
\hline 292 & Online & Online & Blended & Brain + digital & Digital & Digital & Offline & Offline \\
\hline 293 & Online & Online & Blended & Brain + digital & Digital & Non-digital & Online & Online \\
\hline 294 & Online & Online & Blended & Brain + digital & Digital & Non-digital & Online & Offline \\
\hline 295 & Online & Online & Blended & Brain + digital & Digital & Non-digital & Offline & Online \\
\hline 296 & Online & Online & Blended & Brain + digital & Digital & Non-digital & Offline & Offline \\
\hline 297 & Online & Online & Blended & Brain + digital & Digital & Blended & Online & Online \\
\hline 298 & Online & Online & Blended & Brain + digital & Digital & Blended & Online & Offline \\
\hline 299 & Online & Online & Blended & Brain + digital & Digital & Blended & Offline & Online \\
\hline 300 & Online & Online & Blended & Brain + digital & Digital & Blended & Offline & Offline \\
\hline 301 & Online & Online & Blended & Brain + digital & $\begin{array}{l}\text { Non- } \\
\text { digital }\end{array}$ & Digital & Online & Online \\
\hline 302 & Online & Online & Blended & Brain + digital & $\begin{array}{l}\text { Non- } \\
\text { digital }\end{array}$ & Digital & Online & Offline \\
\hline 303 & Online & Online & Blended & Brain + digital & $\begin{array}{l}\text { Non- } \\
\text { digital }\end{array}$ & Digital & Offline & Online \\
\hline 304 & Online & Online & Blended & Brain + digital & $\begin{array}{l}\text { Non- } \\
\text { digital }\end{array}$ & Digital & Offline & Offline \\
\hline 305 & Online & Online & Blended & Brain + digital & $\begin{array}{l}\text { Non- } \\
\text { digital }\end{array}$ & Non-digital & Online & Online \\
\hline 306 & Online & Online & Blended & Brain + digital & $\begin{array}{l}\text { Non- } \\
\text { diqital }\end{array}$ & Non-digital & Online & Offline \\
\hline 307 & Online & Online & Blended & Brain + digital & $\begin{array}{l}\text { Non- } \\
\text { digital }\end{array}$ & Non-digital & Offline & Online \\
\hline 308 & Online & Online & Blended & Brain + digital & $\begin{array}{l}\text { Non- } \\
\text { diqital }\end{array}$ & Non-digital & Offline & Offline \\
\hline 309 & Online & Online & Blended & Brain + digital & $\begin{array}{l}\text { Non- } \\
\text { digital }\end{array}$ & Blended & Online & Online \\
\hline 310 & Online & Online & Blended & Brain + digital & $\begin{array}{l}\text { Non- } \\
\text { digital }\end{array}$ & Blended & Online & Offline \\
\hline
\end{tabular}




\begin{tabular}{|c|c|c|c|c|c|c|c|c|}
\hline 311 & Online & Online & Blended & Brain + digital & $\begin{array}{l}\text { Non- } \\
\text { digital }\end{array}$ & Blended & Offline & Online \\
\hline 312 & Online & Online & Blended & Brain + digital & $\begin{array}{l}\text { Non- } \\
\text { digital }\end{array}$ & Blended & Offline & Offline \\
\hline 313 & Online & Online & Blended & Brain + digital & $\begin{array}{l}\text { Blend- } \\
\text { ed }\end{array}$ & Digital & Online & Online \\
\hline 314 & Online & Online & Blended & Brain + digital & $\begin{array}{l}\text { Blend- } \\
\text { ed }\end{array}$ & Digital & Online & Offline \\
\hline 315 & Online & Online & Blended & Brain + digital & $\begin{array}{l}\text { Blend- } \\
\text { ed }\end{array}$ & Digital & Offline & Online \\
\hline 316 & Online & Online & Blended & Brain + digital & $\begin{array}{l}\text { Blend- } \\
\text { ed }\end{array}$ & Digital & Offline & Offline \\
\hline 317 & Online & Online & Blended & Brain + digital & $\begin{array}{l}\text { Blend- } \\
\text { ed }\end{array}$ & Non-digital & Online & Online \\
\hline 318 & Online & Online & Blended & Brain + digital & $\begin{array}{l}\text { Blend- } \\
\text { ed }\end{array}$ & Non-digital & Online & Offline \\
\hline 319 & Online & Online & Blended & Brain + digital & $\begin{array}{l}\text { Blend- } \\
\text { ed }\end{array}$ & Non-digital & Offline & Online \\
\hline 320 & Online & Online & Blended & Brain + digital & $\begin{array}{l}\text { Blend- } \\
\text { ed }\end{array}$ & Non-digital & Offline & Offline \\
\hline 321 & Online & Online & Blended & Brain + digital & $\begin{array}{l}\text { Blend- } \\
\text { ed }\end{array}$ & Blended & Online & Online \\
\hline 322 & Online & Online & Blended & Brain + digital & $\begin{array}{l}\text { Blend- } \\
\text { ed }\end{array}$ & Blended & Online & Offline \\
\hline 323 & Online & Online & Blended & Brain + digital & $\begin{array}{l}\text { Blend- } \\
\text { ed }\end{array}$ & Blended & Offline & Online \\
\hline 324 & Online & Online & Blended & Brain + digital & $\begin{array}{l}\text { Blend- } \\
\text { ed }\end{array}$ & Blended & Offline & Offline \\
\hline 325 & Online & Online & Blended & Brain & Digital & Digital & Online & Online \\
\hline 326 & Online & Online & Blended & Brain & Digital & Digital & Online & Offline \\
\hline 327 & Online & Online & Blended & Brain & Digital & Digital & Offline & Online \\
\hline 328 & Online & Online & Blended & Brain & Digital & Digital & Offline & Offline \\
\hline 329 & Online & Online & Blended & Brain & Digital & Non-digital & Online & Online \\
\hline 330 & Online & Online & Blended & Brain & Digital & Non-digital & Online & Offline \\
\hline 331 & Online & Online & Blended & Brain & Digital & Non-digital & Offline & Online \\
\hline 332 & Online & Online & Blended & Brain & Digital & Non-digital & Offline & Offline \\
\hline 333 & Online & Online & Blended & Brain & Digital & Blended & Online & Online \\
\hline 334 & Online & Online & Blended & Brain & Digital & Blended & Online & Offline \\
\hline 335 & Online & Online & Blended & Brain & Digital & Blended & Offline & Online \\
\hline 336 & Online & Online & Blended & Brain & Digital & Blended & Offline & Offline \\
\hline 337 & Online & Online & Blended & Brain & $\begin{array}{l}\text { Non- } \\
\text { digital }\end{array}$ & Digital & Online & Online \\
\hline 338 & Online & Online & Blended & Brain & $\begin{array}{l}\text { Non- } \\
\text { digital }\end{array}$ & Digital & Online & Offline \\
\hline 339 & Online & Online & Blended & Brain & $\begin{array}{l}\text { Non- } \\
\text { digital }\end{array}$ & Digital & Offline & Online \\
\hline 340 & Online & Online & Blended & Brain & $\begin{array}{l}\text { Non- } \\
\text { digital }\end{array}$ & Digital & Offline & Offline \\
\hline 341 & Online & Online & Blended & Brain & $\begin{array}{l}\text { Non- } \\
\text { digital }\end{array}$ & Non-digital & Online & Online \\
\hline 342 & Online & Online & Blended & Brain & $\begin{array}{l}\text { Non- } \\
\text { digital }\end{array}$ & Non-digital & Online & Offline \\
\hline 343 & Online & Online & Blended & Brain & $\begin{array}{l}\text { Non- } \\
\text { digital }\end{array}$ & Non-digital & Offline & Online \\
\hline 344 & Online & Online & Blended & Brain & $\begin{array}{l}\text { Non- } \\
\text { diqital }\end{array}$ & Non-digital & Offline & Offline \\
\hline 345 & Online & Online & Blended & Brain & $\begin{array}{l}\text { Non- } \\
\text { digital }\end{array}$ & Blended & Online & Online \\
\hline 346 & Online & Online & Blended & Brain & $\begin{array}{l}\text { Non- } \\
\text { digital }\end{array}$ & Blended & Online & Offline \\
\hline 347 & Online & Online & Blended & Brain & $\begin{array}{l}\text { Non- } \\
\text { diqital }\end{array}$ & Blended & Offline & Online \\
\hline 348 & Online & Online & Blended & Brain & $\begin{array}{l}\text { Non- } \\
\text { digital }\end{array}$ & Blended & Offline & Offline \\
\hline
\end{tabular}




\begin{tabular}{|c|c|c|c|c|c|c|c|c|}
\hline 349 & Online & Online & Blended & Brain & $\begin{array}{l}\text { Blend- } \\
\text { ed }\end{array}$ & Digital & Online & Online \\
\hline 350 & Online & Online & Blended & Brain & $\begin{array}{l}\text { Blend- } \\
\text { ed }\end{array}$ & Digital & Online & Offline \\
\hline 351 & Online & Online & Blended & Brain & $\begin{array}{l}\text { Blend- } \\
\text { ed }\end{array}$ & Digital & Offline & Online \\
\hline 352 & Online & Online & Blended & Brain & $\begin{array}{l}\text { Blend- } \\
\text { ed }\end{array}$ & Digital & Offline & Offline \\
\hline 353 & Online & Online & Blended & Brain & $\begin{array}{l}\text { Blend- } \\
\text { ed }\end{array}$ & Non-digital & Online & Online \\
\hline 354 & Online & Online & Blended & Brain & $\begin{array}{l}\text { Blend- } \\
\text { ed }\end{array}$ & Non-digital & Online & Offline \\
\hline 355 & Online & Online & Blended & Brain & $\begin{array}{l}\text { Blend- } \\
\text { ed }\end{array}$ & Non-digital & Offline & Online \\
\hline 356 & Online & Online & Blended & Brain & $\begin{array}{l}\text { Blend- } \\
\text { ed }\end{array}$ & Non-digital & Offline & Offline \\
\hline 357 & Online & Online & Blended & Brain & $\begin{array}{l}\text { Blend- } \\
\text { ed }\end{array}$ & Blended & Online & Online \\
\hline 358 & Online & Online & Blended & Brain & $\begin{array}{l}\text { Blend- } \\
\text { ed }\end{array}$ & Blended & Online & Offline \\
\hline 359 & Online & Online & Blended & Brain & $\begin{array}{l}\text { Blend- } \\
\text { ed }\end{array}$ & Blended & Offline & Online \\
\hline 360 & Online & Online & Blended & Brain & $\begin{array}{l}\text { Blend- } \\
\text { ed }\end{array}$ & Blended & Offline & Offline \\
\hline 361 & Online & Online & Blended & Brain $+d+n-d$ & Digital & Digital & Online & Online \\
\hline 362 & Online & Online & Blended & Brain $+d+n-d$ & Digital & Digital & Online & Offline \\
\hline 363 & Online & Online & Blended & Brain $+d+n-d$ & Digital & Digital & Offline & Online \\
\hline 364 & Online & Online & Blended & Brain $+d+n-d$ & Digital & Digital & Offline & Offline \\
\hline 365 & Online & Online & Blended & Brain + d + n-d & Digital & Non-digital & Online & Online \\
\hline 366 & Online & Online & Blended & Brain $+d+n-d$ & Digital & Non-digital & Online & Offline \\
\hline 367 & Online & Online & Blended & Brain $+d+n-d$ & Digital & Non-digital & Offline & Online \\
\hline 368 & Online & Online & Blended & Brain $+d+n-d$ & Digital & Non-digital & Offline & Offline \\
\hline 369 & Online & Online & Blended & Brain $+d+n-d$ & Digital & Blended & Online & Online \\
\hline 370 & Online & Online & Blended & Brain $+d+n-d$ & Digital & Blended & Online & Offline \\
\hline 371 & Online & Online & Blended & Brain $+d+n-d$ & Digital & Blended & Offline & Online \\
\hline 372 & Online & Online & Blended & Brain $+d+n-d$ & Digital & Blended & Offline & Offline \\
\hline 373 & Online & Online & Blended & Brain $+d+n-d$ & $\begin{array}{l}\text { Non- } \\
\text { digital }\end{array}$ & Digital & Online & Online \\
\hline 374 & Online & Online & Blended & Brain $+d+n-d$ & $\begin{array}{l}\text { Non- } \\
\text { digital }\end{array}$ & Digital & Online & Offline \\
\hline 375 & Online & Online & Blended & Brain $+d+n-d$ & $\begin{array}{l}\text { Non- } \\
\text { digital }\end{array}$ & Digital & Offline & Online \\
\hline 376 & Online & Online & Blended & Brain $+d+n-d$ & $\begin{array}{l}\text { Non- } \\
\text { digital }\end{array}$ & Digital & Offline & Offline \\
\hline 377 & Online & Online & Blended & Brain + d + n-d & $\begin{array}{l}\text { Non- } \\
\text { digital }\end{array}$ & Non-digital & Online & Online \\
\hline 378 & Online & Online & Blended & Brain + d + n-d & $\begin{array}{l}\text { Non- } \\
\text { digital }\end{array}$ & Non-digital & Online & Offline \\
\hline 379 & Online & Online & Blended & Brain $+d+n-d$ & $\begin{array}{l}\text { Non- } \\
\text { digital }\end{array}$ & Non-digital & Offline & Online \\
\hline 380 & Online & Online & Blended & Brain $+d+n-d$ & $\begin{array}{l}\text { Non- } \\
\text { digital }\end{array}$ & Non-digital & Offline & Offline \\
\hline 381 & Online & Online & Blended & Brain + d + n-d & $\begin{array}{l}\text { Non- } \\
\text { digital }\end{array}$ & Blended & Online & Online \\
\hline 382 & Online & Online & Blended & Brain + d + n-d & $\begin{array}{l}\text { Non- } \\
\text { digital }\end{array}$ & Blended & Online & Offline \\
\hline 383 & Online & Online & Blended & Brain $+d+n-d$ & $\begin{array}{l}\text { Non- } \\
\text { digital }\end{array}$ & Blended & Offline & Online \\
\hline 384 & Online & Online & Blended & Brain + d + n-d & $\begin{array}{l}\text { Non- } \\
\text { digital }\end{array}$ & Blended & Offline & Offline \\
\hline 385 & Online & Online & Blended & Brain + d + n-d & $\begin{array}{l}\text { Blend- } \\
\text { ed }\end{array}$ & Digital & Online & Online \\
\hline 386 & Online & Online & Blended & Brain + d + n-d & $\begin{array}{l}\text { Blend- } \\
\text { ed }\end{array}$ & Digital & Online & Offline \\
\hline
\end{tabular}




\begin{tabular}{|c|c|c|c|c|c|c|c|c|}
\hline 387 & Online & Online & Blended & Brain $+d+n-d$ & $\begin{array}{l}\text { Blend- } \\
\text { ed }\end{array}$ & Digital & Offline & Online \\
\hline 388 & Online & Online & Blended & Brain $+d+n-d$ & $\begin{array}{l}\text { Blend- } \\
\text { ed }\end{array}$ & Digital & Offline & Offline \\
\hline 389 & Online & Online & Blended & Brain $+d+n-d$ & $\begin{array}{l}\text { Blend- } \\
\text { ed }\end{array}$ & Non-digital & Online & Online \\
\hline 390 & Online & Online & Blended & Brain $+d+n-d$ & $\begin{array}{l}\text { Blend- } \\
\text { ed }\end{array}$ & Non-digital & Online & Offline \\
\hline 391 & Online & Online & Blended & Brain $+d+n-d$ & $\begin{array}{l}\text { Blend- } \\
\text { ed }\end{array}$ & Non-digital & Offline & Online \\
\hline 392 & Online & Online & Blended & Brain $+d+n-d$ & $\begin{array}{l}\text { Blend- } \\
\text { ed }\end{array}$ & Non-digital & Offline & Offline \\
\hline 393 & Online & Online & Blended & Brain $+d+n-d$ & $\begin{array}{l}\text { Blend- } \\
\text { ed }\end{array}$ & Blended & Online & Online \\
\hline 394 & Online & Online & Blended & Brain $+d+n-d$ & $\begin{array}{l}\text { Blend- } \\
\text { ed }\end{array}$ & Blended & Online & Offline \\
\hline 395 & Online & Online & Blended & Brain $+d+n-d$ & $\begin{array}{l}\text { Blend- } \\
\text { ed }\end{array}$ & Blended & Offline & Online \\
\hline 396 & Online & Online & Blended & Brain $+d+n-d$ & $\begin{array}{l}\text { Blend- } \\
\text { ed }\end{array}$ & Blended & Offline & Offline \\
\hline 397 & Online & Online & Blended & Brain $+n-d$ & Digital & Digital & Online & Online \\
\hline 398 & Online & Online & Blended & Brain $+n-d$ & Digital & Digital & Online & Offline \\
\hline 399 & Online & Online & Blended & Brain $+n-d$ & Digital & Digital & Offline & Online \\
\hline 400 & Online & Online & Blended & Brain + n-d & Digital & Digital & Offline & Offline \\
\hline 401 & Online & Online & Blended & Brain $+n-d$ & Digital & Non-digital & Online & Online \\
\hline 402 & Online & Online & Blended & Brain $+n-d$ & Digital & Non-digital & Online & Offline \\
\hline 403 & Online & Online & Blended & Brain $+n-d$ & Digital & Non-digital & Offline & Online \\
\hline 404 & Online & Online & Blended & Brain $+n-d$ & Digital & Non-digital & Offline & Offline \\
\hline 405 & Online & Online & Blended & Brain $+n-d$ & Digital & Blended & Online & Online \\
\hline 406 & Online & Online & Blended & Brain $+n-d$ & Digital & Blended & Online & Offline \\
\hline 407 & Online & Online & Blended & Brain + n-d & Digital & Blended & Offline & Online \\
\hline 408 & Online & Online & Blended & Brain $+n-d$ & Digital & Blended & Offline & Offline \\
\hline 409 & Online & Online & Blended & Brain + n-d & $\begin{array}{l}\text { Non- } \\
\text { digital }\end{array}$ & Digital & Online & Online \\
\hline 410 & Online & Online & Blended & Brain $+n-d$ & $\begin{array}{l}\text { Non- } \\
\text { digital }\end{array}$ & Digital & Online & Offline \\
\hline 411 & Online & Online & Blended & Brain $+n-d$ & $\begin{array}{l}\text { Non- } \\
\text { digital }\end{array}$ & Digital & Offline & Online \\
\hline 412 & Online & Online & Blended & Brain + n-d & $\begin{array}{l}\text { Non- } \\
\text { digital }\end{array}$ & Digital & Offline & Offline \\
\hline 413 & Online & Online & Blended & Brain $+n-d$ & $\begin{array}{l}\text { Non- } \\
\text { digital }\end{array}$ & Non-digital & Online & Online \\
\hline 414 & Online & Online & Blended & Brain $+n-d$ & $\begin{array}{l}\text { Non- } \\
\text { diqital }\end{array}$ & Non-digital & Online & Offline \\
\hline 415 & Online & Online & Blended & Brain $+n-d$ & $\begin{array}{l}\text { Non- } \\
\text { digital }\end{array}$ & Non-digital & Offline & Online \\
\hline 416 & Online & Online & Blended & Brain + n-d & $\begin{array}{l}\text { Non- } \\
\text { digital }\end{array}$ & Non-digital & Offline & Offline \\
\hline 417 & Online & Online & Blended & Brain + n-d & $\begin{array}{l}\text { Non- } \\
\text { digital }\end{array}$ & Blended & Online & Online \\
\hline 418 & Online & Online & Blended & Brain $+n-d$ & $\begin{array}{l}\text { Non- } \\
\text { digital }\end{array}$ & Blended & Online & Offline \\
\hline 419 & Online & Online & Blended & Brain + n-d & $\begin{array}{l}\text { Non- } \\
\text { digital }\end{array}$ & Blended & Offline & Online \\
\hline 420 & Online & Online & Blended & Brain + n-d & $\begin{array}{l}\text { Non- } \\
\text { digital }\end{array}$ & Blended & Offline & Offline \\
\hline 421 & Online & Online & Blended & Brain $+n-d$ & $\begin{array}{l}\text { Blend- } \\
\text { ed }\end{array}$ & Digital & Online & Online \\
\hline 422 & Online & Online & Blended & Brain + n-d & $\begin{array}{l}\text { Blend- } \\
\text { ed }\end{array}$ & Digital & Online & Offline \\
\hline 423 & Online & Online & Blended & Brain + n-d & $\begin{array}{l}\text { Blend- } \\
\text { ed }\end{array}$ & Digital & Offline & Online \\
\hline 424 & Online & Online & Blended & Brain $+n-d$ & $\begin{array}{l}\text { Blend- } \\
\text { ed }\end{array}$ & Digital & Offline & Offline \\
\hline
\end{tabular}




\begin{tabular}{|c|c|c|c|c|c|c|c|c|}
\hline 425 & Online & Online & Blended & Brain + n-d & $\begin{array}{l}\text { Blend- } \\
\text { ed }\end{array}$ & Non-digital & Online & Online \\
\hline 426 & Online & Online & Blended & Brain + n-d & $\begin{array}{l}\text { Blend- } \\
\text { ed }\end{array}$ & Non-digital & Online & Offline \\
\hline 427 & Online & Online & Blended & Brain + n-d & $\begin{array}{l}\text { Blend- } \\
\text { ed }\end{array}$ & Non-digital & Offline & Online \\
\hline 428 & Online & Online & Blended & Brain + n-d & $\begin{array}{l}\text { Blend- } \\
\text { ed }\end{array}$ & Non-digital & Offline & Offline \\
\hline 429 & Online & Online & Blended & Brain + n-d & $\begin{array}{l}\text { Blend- } \\
\text { ed }\end{array}$ & Blended & Online & Online \\
\hline 430 & Online & Online & Blended & Brain + n-d & $\begin{array}{l}\text { Blend- } \\
\text { ed }\end{array}$ & Blended & Online & Offline \\
\hline 431 & Online & Online & Blended & Brain + n-d & $\begin{array}{l}\text { Blend- } \\
\text { ed }\end{array}$ & Blended & Offline & Online \\
\hline 432 & Online & Online & Blended & Brain + n-d & $\begin{array}{l}\text { Blend- } \\
\text { ed }\end{array}$ & Blended & Offline & Offline \\
\hline 433 & Online & Offline & Online & Brain + digital & Digital & Digital & Online & Online \\
\hline 434 & Online & Offline & Online & Brain + digital & Digital & Digital & Online & Offline \\
\hline 435 & Online & Offline & Online & Brain + digital & Digital & Digital & Offline & Online \\
\hline 436 & Online & Offline & Online & Brain + digital & Digital & Digital & Offline & Offline \\
\hline 437 & Online & Offline & Online & Brain + digital & Digital & Non-digital & Online & Online \\
\hline 438 & Online & Offline & Online & Brain + digital & Digital & Non-digital & Online & Offline \\
\hline 439 & Online & Offline & Online & Brain + digital & Digital & Non-digital & Offline & Online \\
\hline 440 & Online & Offline & Online & Brain + digital & Digital & Non-digital & Offline & Offline \\
\hline 441 & Online & Offline & Online & Brain + digital & Digital & Blended & Online & Online \\
\hline 442 & Online & Offline & Online & Brain + digital & Digital & Blended & Online & Offline \\
\hline 443 & Online & Offline & Online & Brain + digital & Digital & Blended & Offline & Online \\
\hline 444 & Online & Offline & Online & Brain + digital & Digital & Blended & Offline & Offline \\
\hline 445 & Online & Offline & Online & Brain + digital & $\begin{array}{l}\text { Non- } \\
\text { digital }\end{array}$ & Digital & Online & Online \\
\hline 446 & Online & Offline & Online & Brain + digital & $\begin{array}{l}\text { Non- } \\
\text { digital }\end{array}$ & Digital & Online & Offline \\
\hline 447 & Online & Offline & Online & Brain + digital & $\begin{array}{l}\text { Non- } \\
\text { digital }\end{array}$ & Digital & Offline & Online \\
\hline 448 & Online & Offline & Online & Brain + digital & $\begin{array}{l}\text { Non- } \\
\text { digital }\end{array}$ & Digital & Offline & Offline \\
\hline 449 & Online & Offline & Online & Brain + digital & $\begin{array}{l}\text { Non- } \\
\text { digital }\end{array}$ & Non-digital & Online & Online \\
\hline 450 & Online & Offline & Online & Brain + digital & $\begin{array}{l}\text { Non- } \\
\text { digital }\end{array}$ & Non-digital & Online & Offline \\
\hline 451 & Online & Offline & Online & Brain + digital & $\begin{array}{l}\text { Non- } \\
\text { digital }\end{array}$ & Non-digital & Offline & Online \\
\hline 452 & Online & Offline & Online & Brain + digital & $\begin{array}{l}\text { Non- } \\
\text { digital }\end{array}$ & Non-digital & Offline & Offline \\
\hline 453 & Online & Offline & Online & Brain + digital & $\begin{array}{l}\text { Non- } \\
\text { digital }\end{array}$ & Blended & Online & Online \\
\hline 454 & Online & Offline & Online & Brain + digital & $\begin{array}{l}\text { Non- } \\
\text { digital }\end{array}$ & Blended & Online & Offline \\
\hline 455 & Online & Offline & Online & Brain + digital & $\begin{array}{l}\text { Non- } \\
\text { digital }\end{array}$ & Blended & Offline & Online \\
\hline 456 & Online & Offline & Online & Brain + digital & $\begin{array}{l}\text { Non- } \\
\text { digital }\end{array}$ & Blended & Offline & Offline \\
\hline 457 & Online & Offline & Online & Brain + digital & $\begin{array}{l}\text { Blend- } \\
\text { ed }\end{array}$ & Digital & Online & Online \\
\hline 458 & Online & Offline & Online & Brain + digital & $\begin{array}{l}\text { Blend- } \\
\text { ed }\end{array}$ & Digital & Online & Offline \\
\hline 459 & Online & Offline & Online & Brain + digital & $\begin{array}{l}\text { Blend- } \\
\text { ed }\end{array}$ & Digital & Offline & Online \\
\hline 460 & Online & Offline & Online & Brain + digital & $\begin{array}{l}\text { Blend- } \\
\text { ed }\end{array}$ & Digital & Offline & Offline \\
\hline 461 & Online & Offline & Online & Brain + digital & $\begin{array}{l}\text { Blend- } \\
\text { ed }\end{array}$ & Non-digital & Online & Online \\
\hline 462 & Online & Offline & Online & Brain + digital & $\begin{array}{l}\text { Blend- } \\
\text { ed }\end{array}$ & Non-digital & Online & Offline \\
\hline
\end{tabular}




\begin{tabular}{|c|c|c|c|c|c|c|c|c|}
\hline 463 & Online & Offline & Online & Brain + digital & $\begin{array}{l}\text { Blend- } \\
\text { ed }\end{array}$ & Non-digital & Offline & Online \\
\hline 464 & Online & Offline & Online & Brain + digital & $\begin{array}{l}\text { Blend- } \\
\text { ed }\end{array}$ & Non-digital & Offline & Offline \\
\hline 465 & Online & Offline & Online & Brain + digital & $\begin{array}{l}\text { Blend- } \\
\text { ed }\end{array}$ & Blended & Online & Online \\
\hline 466 & Online & Offline & Online & Brain + digital & $\begin{array}{l}\text { Blend- } \\
\text { ed }\end{array}$ & Blended & Online & Offline \\
\hline 467 & Online & Offline & Online & Brain + digital & $\begin{array}{l}\text { Blend- } \\
\text { ed }\end{array}$ & Blended & Offline & Online \\
\hline 468 & Online & Offline & Online & Brain + digital & $\begin{array}{l}\text { Blend- } \\
\text { ed }\end{array}$ & Blended & Offline & Offline \\
\hline 469 & Online & Offline & Online & Brain & Digital & Digital & Online & Online \\
\hline 470 & Online & Offline & Online & Brain & Digital & Digital & Online & Offline \\
\hline 471 & Online & Offline & Online & Brain & Digital & Digital & Offline & Online \\
\hline 472 & Online & Offline & Online & Brain & Digital & Digital & Offline & Offline \\
\hline 473 & Online & Offline & Online & Brain & Digital & Non-digital & Online & Online \\
\hline 474 & Online & Offline & Online & Brain & Digital & Non-digital & Online & Offline \\
\hline 475 & Online & Offline & Online & Brain & Digital & Non-digital & Offline & Online \\
\hline 476 & Online & Offline & Online & Brain & Digital & Non-digital & Offline & Offline \\
\hline 477 & Online & Offline & Online & Brain & Digital & Blended & Online & Online \\
\hline 478 & Online & Offline & Online & Brain & Digital & Blended & Online & Offline \\
\hline 479 & Online & Offline & Online & Brain & Digital & Blended & Offline & Online \\
\hline 480 & Online & Offline & Online & Brain & Digital & Blended & Offline & Offline \\
\hline 481 & Online & Offline & Online & Brain & $\begin{array}{l}\text { Non- } \\
\text { digital }\end{array}$ & Digital & Online & Online \\
\hline 482 & Online & Offline & Online & Brain & $\begin{array}{l}\text { Non- } \\
\text { digital }\end{array}$ & Digital & Online & Offline \\
\hline 483 & Online & Offline & Online & Brain & $\begin{array}{l}\text { Non- } \\
\text { digital }\end{array}$ & Digital & Offline & Online \\
\hline 484 & Online & Offline & Online & Brain & $\begin{array}{l}\text { Non- } \\
\text { digital }\end{array}$ & Digital & Offline & Offline \\
\hline 485 & Online & Offline & Online & Brain & $\begin{array}{l}\text { Non- } \\
\text { digital }\end{array}$ & Non-digital & Online & Online \\
\hline 486 & Online & Offline & Online & Brain & $\begin{array}{l}\text { Non- } \\
\text { digital }\end{array}$ & Non-digital & Online & Offline \\
\hline 487 & Online & Offline & Online & Brain & $\begin{array}{l}\text { Non- } \\
\text { digital }\end{array}$ & Non-digital & Offline & Online \\
\hline 488 & Online & Offline & Online & Brain & $\begin{array}{l}\text { Non- } \\
\text { digital }\end{array}$ & Non-digital & Offline & Offline \\
\hline 489 & Online & Offline & Online & Brain & $\begin{array}{l}\text { Non- } \\
\text { digital }\end{array}$ & Blended & Online & Online \\
\hline 490 & Online & Offline & Online & Brain & $\begin{array}{l}\text { Non- } \\
\text { diqital }\end{array}$ & Blended & Online & Offline \\
\hline 491 & Online & Offline & Online & Brain & $\begin{array}{l}\text { Non- } \\
\text { digital }\end{array}$ & Blended & Offline & Online \\
\hline 492 & Online & Offline & Online & Brain & $\begin{array}{l}\text { Non- } \\
\text { digital }\end{array}$ & Blended & Offline & Offline \\
\hline 493 & Online & Offline & Online & Brain & $\begin{array}{l}\text { Blend- } \\
\text { ed }\end{array}$ & Digital & Online & Online \\
\hline 494 & Online & Offline & Online & Brain & $\begin{array}{l}\text { Blend- } \\
\text { ed }\end{array}$ & Digital & Online & Offline \\
\hline 495 & Online & Offline & Online & Brain & $\begin{array}{l}\text { Blend- } \\
\text { ed }\end{array}$ & Digital & Offline & Online \\
\hline 496 & Online & Offline & Online & Brain & $\begin{array}{l}\text { Blend- } \\
\text { ed }\end{array}$ & Digital & Offline & Offline \\
\hline 497 & Online & Offline & Online & Brain & $\begin{array}{l}\text { Blend- } \\
\text { ed }\end{array}$ & Non-digital & Online & Online \\
\hline 498 & Online & Offline & Online & Brain & $\begin{array}{l}\text { Blend- } \\
\text { ed }\end{array}$ & Non-digital & Online & Offline \\
\hline 499 & Online & Offline & Online & Brain & $\begin{array}{l}\text { Blend- } \\
\text { ed }\end{array}$ & Non-digital & Offline & Online \\
\hline 500 & Online & Offline & Online & Brain & $\begin{array}{l}\text { Blend- } \\
\text { ed }\end{array}$ & Non-digital & Offline & Offline \\
\hline
\end{tabular}




\begin{tabular}{|c|c|c|c|c|c|c|c|c|}
\hline 501 & Online & Offline & Online & Brain & $\begin{array}{l}\text { Blend- } \\
\text { ed }\end{array}$ & Blended & Online & Online \\
\hline 502 & Online & Offline & Online & Brain & $\begin{array}{l}\text { Blend- } \\
\text { ed }\end{array}$ & Blended & Online & Offline \\
\hline 503 & Online & Offline & Online & Brain & $\begin{array}{l}\text { Blend- } \\
\text { ed }\end{array}$ & Blended & Offline & Online \\
\hline 504 & Online & Offline & Online & Brain & $\begin{array}{l}\text { Blend- } \\
\text { ed }\end{array}$ & Blended & Offline & Offline \\
\hline 505 & Online & Offline & Online & Brain $+d+n-d$ & Digital & Digital & Online & Online \\
\hline 506 & Online & Offline & Online & Brain $+d+n-d$ & Digital & Digital & Online & Offline \\
\hline 507 & Online & Offline & Online & Brain $+d+n-d$ & Digital & Digital & Offline & Online \\
\hline 508 & Online & Offline & Online & Brain $+d+n-d$ & Digital & Digital & Offline & Offline \\
\hline 509 & Online & Offline & Online & Brain $+d+n-d$ & Digital & Non-digital & Online & Online \\
\hline 510 & Online & Offline & Online & Brain $+d+n-d$ & Digital & Non-digital & Online & Offline \\
\hline 511 & Online & Offline & Online & Brain $+d+n-d$ & Digital & Non-digital & Offline & Online \\
\hline 512 & Online & Offline & Online & Brain $+d+n-d$ & Digital & Non-digital & Offline & Offline \\
\hline 513 & Online & Offline & Online & Brain $+d+n-d$ & Digital & Blended & Online & Online \\
\hline 514 & Online & Offline & Online & Brain $+d+n-d$ & Digital & Blended & Online & Offline \\
\hline 515 & Online & Offline & Online & Brain $+d+n-d$ & Digital & Blended & Offline & Online \\
\hline 516 & Online & Offline & Online & Brain $+d+n-d$ & Digital & Blended & Offline & Offline \\
\hline 517 & Online & Offline & Online & Brain $+d+n-d$ & $\begin{array}{l}\text { Non- } \\
\text { digital }\end{array}$ & Digital & Online & Online \\
\hline 518 & Online & Offline & Online & Brain $+d+n-d$ & $\begin{array}{l}\text { Non- } \\
\text { digital }\end{array}$ & Digital & Online & Offline \\
\hline 519 & Online & Offline & Online & Brain $+d+n-d$ & $\begin{array}{l}\text { Non- } \\
\text { digital }\end{array}$ & Digital & Offline & Online \\
\hline 520 & Online & Offline & Online & Brain $+d+n-d$ & $\begin{array}{l}\text { Non- } \\
\text { digital }\end{array}$ & Digital & Offline & Offline \\
\hline 521 & Online & Offline & Online & Brain $+d+n-d$ & $\begin{array}{l}\text { Non- } \\
\text { digital }\end{array}$ & Non-digital & Online & Online \\
\hline 522 & Online & Offline & Online & Brain $+d+n-d$ & $\begin{array}{l}\text { Non- } \\
\text { digital }\end{array}$ & Non-digital & Online & Offline \\
\hline 523 & Online & Offline & Online & Brain $+d+n-d$ & $\begin{array}{l}\text { Non- } \\
\text { digital }\end{array}$ & Non-digital & Offline & Online \\
\hline 524 & Online & Offline & Online & Brain $+d+n-d$ & $\begin{array}{l}\text { Non- } \\
\text { digital }\end{array}$ & Non-digital & Offline & Offline \\
\hline 525 & Online & Offline & Online & Brain $+d+n-d$ & $\begin{array}{l}\text { Non- } \\
\text { digital }\end{array}$ & Blended & Online & Online \\
\hline 526 & Online & Offline & Online & Brain $+d+n-d$ & $\begin{array}{l}\text { Non- } \\
\text { digital }\end{array}$ & Blended & Online & Offline \\
\hline 527 & Online & Offline & Online & Brain $+d+n-d$ & $\begin{array}{l}\text { Non- } \\
\text { digital }\end{array}$ & Blended & Offline & Online \\
\hline 528 & Online & Offline & Online & Brain $+d+n-d$ & $\begin{array}{l}\text { Non- } \\
\text { digital }\end{array}$ & Blended & Offline & Offline \\
\hline 529 & Online & Offline & Online & Brain + d + n-d & $\begin{array}{l}\text { Blend- } \\
\text { ed }\end{array}$ & Digital & Online & Online \\
\hline 530 & Online & Offline & Online & Brain $+d+n-d$ & $\begin{array}{l}\text { Blend- } \\
\text { ed }\end{array}$ & Digital & Online & Offline \\
\hline 531 & Online & Offline & Online & Brain $+d+n-d$ & $\begin{array}{l}\text { Blend- } \\
\text { ed }\end{array}$ & Digital & Offline & Online \\
\hline 532 & Online & Offline & Online & Brain $+d+n-d$ & $\begin{array}{l}\text { Blend- } \\
\text { ed }\end{array}$ & Digital & Offline & Offline \\
\hline 533 & Online & Offline & Online & Brain $+d+n-d$ & $\begin{array}{l}\text { Blend- } \\
\text { ed }\end{array}$ & Non-digital & Online & Online \\
\hline 534 & Online & Offline & Online & Brain $+d+n-d$ & $\begin{array}{l}\text { Blend- } \\
\text { ed }\end{array}$ & Non-digital & Online & Offline \\
\hline 535 & Online & Offline & Online & Brain $+d+n-d$ & $\begin{array}{l}\text { Blend- } \\
\text { ed }\end{array}$ & Non-digital & Offline & Online \\
\hline 536 & Online & Offline & Online & Brain $+d+n-d$ & $\begin{array}{l}\text { Blend- } \\
\text { ed }\end{array}$ & Non-digital & Offline & Offline \\
\hline 537 & Online & Offline & Online & Brain $+d+n-d$ & $\begin{array}{l}\text { Blend- } \\
\text { ed }\end{array}$ & Blended & Online & Online \\
\hline 538 & Online & Offline & Online & Brain $+d+n-d$ & $\begin{array}{l}\text { Blend- } \\
\text { ed }\end{array}$ & Blended & Online & Offline \\
\hline
\end{tabular}




\begin{tabular}{|c|c|c|c|c|c|c|c|c|}
\hline 539 & Online & Offline & Online & Brain $+d+n-d$ & $\begin{array}{l}\text { Blend- } \\
\text { ed }\end{array}$ & Blended & Offline & Online \\
\hline 540 & Online & Offline & Online & Brain $+d+n-d$ & $\begin{array}{l}\text { Blend- } \\
\text { ed }\end{array}$ & Blended & Offline & Offline \\
\hline 541 & Online & Offline & Online & Brain + n-d & Digital & Digital & Online & Online \\
\hline 542 & Online & Offline & Online & Brain + n-d & Digital & Digital & Online & Offline \\
\hline 543 & Online & Offline & Online & Brain + n-d & Digital & Digital & Offline & Online \\
\hline 544 & Online & Offline & Online & Brain + n-d & Digital & Digital & Offline & Offline \\
\hline 545 & Online & Offline & Online & Brain + n-d & Digital & Non-digital & Online & Online \\
\hline 546 & Online & Offline & Online & Brain + n-d & Digital & Non-digital & Online & Offline \\
\hline 547 & Online & Offline & Online & Brain + n-d & Digital & Non-digital & Offline & Online \\
\hline 548 & Online & Offline & Online & Brain + n-d & Digital & Non-digital & Offline & Offline \\
\hline 549 & Online & Offline & Online & Brain + n-d & Digital & Blended & Online & Online \\
\hline 550 & Online & Offline & Online & Brain + n-d & Digital & Blended & Online & Offline \\
\hline 551 & Online & Offline & Online & Brain $+n-d$ & Digital & Blended & Offline & Online \\
\hline 552 & Online & Offline & Online & Brain + n-d & Digital & Blended & Offline & Offline \\
\hline 553 & Online & Offline & Online & Brain + n-d & $\begin{array}{l}\text { Non- } \\
\text { digital }\end{array}$ & Digital & Online & Online \\
\hline 554 & Online & Offline & Online & Brain + n-d & $\begin{array}{l}\text { Non- } \\
\text { digital }\end{array}$ & Digital & Online & Offline \\
\hline 555 & Online & Offline & Online & Brain + n-d & $\begin{array}{l}\text { Non- } \\
\text { digital }\end{array}$ & Digital & Offline & Online \\
\hline 556 & Online & Offline & Online & Brain + n-d & $\begin{array}{l}\text { Non- } \\
\text { digital }\end{array}$ & Digital & Offline & Offline \\
\hline 557 & Online & Offline & Online & Brain + n-d & $\begin{array}{l}\text { Non- } \\
\text { digital }\end{array}$ & Non-digital & Online & Online \\
\hline 558 & Online & Offline & Online & Brain + n-d & $\begin{array}{l}\text { Non- } \\
\text { digital }\end{array}$ & Non-digital & Online & Offline \\
\hline 559 & Online & Offline & Online & Brain + n-d & $\begin{array}{l}\text { Non- } \\
\text { digital }\end{array}$ & Non-digital & Offline & Online \\
\hline 560 & Online & Offline & Online & Brain + n-d & $\begin{array}{l}\text { Non- } \\
\text { digital }\end{array}$ & Non-digital & Offline & Offline \\
\hline 561 & Online & Offline & Online & Brain + n-d & $\begin{array}{l}\text { Non- } \\
\text { digital }\end{array}$ & Blended & Online & Online \\
\hline 562 & Online & Offline & Online & Brain + n-d & $\begin{array}{l}\text { Non- } \\
\text { digital }\end{array}$ & Blended & Online & Offline \\
\hline 563 & Online & Offline & Online & Brain + n-d & $\begin{array}{l}\text { Non- } \\
\text { digital }\end{array}$ & Blended & Offline & Online \\
\hline 564 & Online & Offline & Online & Brain + n-d & $\begin{array}{l}\text { Non- } \\
\text { digital }\end{array}$ & Blended & Offline & Offline \\
\hline 565 & Online & Offline & Online & Brain + n-d & $\begin{array}{l}\text { Blend- } \\
\text { ed }\end{array}$ & Digital & Online & Online \\
\hline 566 & Online & Offline & Online & Brain + n-d & $\begin{array}{l}\text { Blend- } \\
\text { ed }\end{array}$ & Digital & Online & Offline \\
\hline 567 & Online & Offline & Online & Brain + n-d & $\begin{array}{l}\text { Blend- } \\
\text { ed }\end{array}$ & Digital & Offline & Online \\
\hline 568 & Online & Offline & Online & Brain + n-d & $\begin{array}{l}\text { Blend- } \\
\text { ed }\end{array}$ & Digital & Offline & Offline \\
\hline 569 & Online & Offline & Online & Brain + n-d & $\begin{array}{l}\text { Blend- } \\
\text { ed }\end{array}$ & Non-digital & Online & Online \\
\hline 570 & Online & Offline & Online & Brain + n-d & $\begin{array}{l}\text { Blend- } \\
\text { ed }\end{array}$ & Non-digital & Online & Offline \\
\hline 571 & Online & Offline & Online & Brain + n-d & $\begin{array}{l}\text { Blend- } \\
\text { ed }\end{array}$ & Non-digital & Offline & Online \\
\hline 572 & Online & Offline & Online & Brain + n-d & $\begin{array}{l}\text { Blend- } \\
\text { ed }\end{array}$ & Non-digital & Offline & Offline \\
\hline 573 & Online & Offline & Online & Brain + n-d & $\begin{array}{l}\text { Blend- } \\
\text { ed }\end{array}$ & Blended & Online & Online \\
\hline 574 & Online & Offline & Online & Brain + n-d & $\begin{array}{l}\text { Blend- } \\
\text { ed }\end{array}$ & Blended & Online & Offline \\
\hline 575 & Online & Offline & Online & Brain + n-d & $\begin{array}{l}\text { Blend- } \\
\text { ed }\end{array}$ & Blended & Offline & Online \\
\hline 576 & Online & Offline & Online & Brain + n-d & $\begin{array}{l}\text { Blend- } \\
\text { ed }\end{array}$ & Blended & Offline & Offline \\
\hline 577 & Online & Offline & Offline & Brain + digital & Digital & Digital & Online & Online \\
\hline
\end{tabular}




\begin{tabular}{|c|c|c|c|c|c|c|c|c|}
\hline 578 & Online & Offline & Offline & Brain + digital & Digital & Digital & Online & Offline \\
\hline 579 & Online & Offline & Offline & Brain + digital & Digital & Digital & Offline & Online \\
\hline 580 & Online & Offline & Offline & Brain + digital & Digital & Digital & Offline & Offline \\
\hline 581 & Online & Offline & Offline & Brain + digital & Digital & Non-digital & Online & Online \\
\hline 582 & Online & Offline & Offline & Brain + digital & Digital & Non-digital & Online & Offline \\
\hline 583 & Online & Offline & Offline & Brain + digital & Digital & Non-digital & Offline & Online \\
\hline 584 & Online & Offline & Offline & Brain + digital & Digital & Non-digital & Offline & Offline \\
\hline 585 & Online & Offline & Offline & Brain + digital & Digital & Blended & Online & Online \\
\hline 586 & Online & Offline & Offline & Brain + digital & Digital & Blended & Online & Offline \\
\hline 587 & Online & Offline & Offline & Brain + digital & Digital & Blended & Offline & Online \\
\hline 588 & Online & Offline & Offline & Brain + digital & Digital & Blended & Offline & Offline \\
\hline 589 & Online & Offline & Offline & Brain + digital & $\begin{array}{l}\text { Non- } \\
\text { digital }\end{array}$ & Digital & Online & Online \\
\hline 590 & Online & Offline & Offline & Brain + digital & $\begin{array}{l}\text { Non- } \\
\text { digital }\end{array}$ & Digital & Online & Offline \\
\hline 591 & Online & Offline & Offline & Brain + digital & $\begin{array}{l}\text { Non- } \\
\text { digital }\end{array}$ & Digital & Offline & Online \\
\hline 592 & Online & Offline & Offline & Brain + digital & $\begin{array}{l}\text { Non- } \\
\text { digital }\end{array}$ & Digital & Offline & Offline \\
\hline 593 & Online & Offline & Offline & Brain + digital & $\begin{array}{l}\text { Non- } \\
\text { digital }\end{array}$ & Non-digital & Online & Online \\
\hline 594 & Online & Offline & Offline & Brain + digital & $\begin{array}{l}\text { Non- } \\
\text { digital }\end{array}$ & Non-digital & Online & Offline \\
\hline 595 & Online & Offline & Offline & Brain + digital & $\begin{array}{l}\text { Non- } \\
\text { digital }\end{array}$ & Non-digital & Offline & Online \\
\hline 596 & Online & Offline & Offline & Brain + digital & $\begin{array}{l}\text { Non- } \\
\text { digital }\end{array}$ & Non-digital & Offline & Offline \\
\hline 597 & Online & Offline & Offline & Brain + digital & $\begin{array}{l}\text { Non- } \\
\text { digital }\end{array}$ & Blended & Online & Online \\
\hline 598 & Online & Offline & Offline & Brain + digital & $\begin{array}{l}\text { Non- } \\
\text { digital }\end{array}$ & Blended & Online & Offline \\
\hline 599 & Online & Offline & Offline & Brain + digital & $\begin{array}{l}\text { Non- } \\
\text { digital }\end{array}$ & Blended & Offline & Online \\
\hline 600 & Online & Offline & Offline & Brain + digital & $\begin{array}{l}\text { Non- } \\
\text { digital }\end{array}$ & Blended & Offline & Offline \\
\hline 601 & Online & Offline & Offline & Brain + digital & $\begin{array}{l}\text { Blend- } \\
\text { ed }\end{array}$ & Digital & Online & Online \\
\hline 602 & Online & Offline & Offline & Brain + digital & $\begin{array}{l}\text { Blend- } \\
\text { ed }\end{array}$ & Digital & Online & Offline \\
\hline 603 & Online & Offline & Offline & Brain + digital & $\begin{array}{l}\text { Blend- } \\
\text { ed }\end{array}$ & Digital & Offline & Online \\
\hline 604 & Online & Offline & Offline & Brain + digital & $\begin{array}{l}\text { Blend- } \\
\text { ed }\end{array}$ & Digital & Offline & Offline \\
\hline 605 & Online & Offline & Offline & Brain + digital & $\begin{array}{l}\text { Blend- } \\
\text { ed }\end{array}$ & Non-digital & Online & Online \\
\hline 606 & Online & Offline & Offline & Brain + digital & $\begin{array}{l}\text { Blend- } \\
\text { ed }\end{array}$ & Non-digital & Online & Offline \\
\hline 607 & Online & Offline & Offline & Brain + digital & $\begin{array}{l}\text { Blend- } \\
\text { ed }\end{array}$ & Non-digital & Offline & Online \\
\hline 608 & Online & Offline & Offline & Brain + digital & $\begin{array}{l}\text { Blend- } \\
\text { ed }\end{array}$ & Non-digital & Offline & Offline \\
\hline 609 & Online & Offline & Offline & Brain + digital & $\begin{array}{l}\text { Blend- } \\
\text { ed }\end{array}$ & Blended & Online & Online \\
\hline 610 & Online & Offline & Offline & Brain + digital & $\begin{array}{l}\text { Blend- } \\
\text { ed }\end{array}$ & Blended & Online & Offline \\
\hline 611 & Online & Offline & Offline & Brain + digital & $\begin{array}{l}\text { Blend- } \\
\text { ed }\end{array}$ & Blended & Offline & Online \\
\hline 612 & Online & Offline & Offline & Brain + digital & $\begin{array}{l}\text { Blend- } \\
\text { ed }\end{array}$ & Blended & Offline & Offline \\
\hline 613 & Online & Offline & Offline & Brain & Digital & Digital & Online & Online \\
\hline 614 & Online & Offline & Offline & Brain & Digital & Digital & Online & Offline \\
\hline 615 & Online & Offline & Offline & Brain & Digital & Digital & Offline & Online \\
\hline 616 & Online & Offline & Offline & Brain & Digital & Digital & Offline & Offline \\
\hline 617 & Online & Offline & Offline & Brain & Digital & Non-digital & Online & Online \\
\hline 618 & Online & Offline & Offline & Brain & Digital & Non-digital & Online & Offline \\
\hline
\end{tabular}




\begin{tabular}{|c|c|c|c|c|c|c|c|c|}
\hline 619 & Online & Offline & Offline & Brain & Digital & Non-digital & Offline & Online \\
\hline 620 & Online & Offline & Offline & Brain & Digital & Non-digital & Offline & Offline \\
\hline 621 & Online & Offline & Offline & Brain & Digital & Blended & Online & Online \\
\hline 622 & Online & Offline & Offline & Brain & Digital & Blended & Online & Offline \\
\hline 623 & Online & Offline & Offline & Brain & Digital & Blended & Offline & Online \\
\hline 624 & Online & Offline & Offline & Brain & Digital & Blended & Offline & Offline \\
\hline 625 & Online & Offline & Offline & Brain & $\begin{array}{l}\text { Non- } \\
\text { digital }\end{array}$ & Digital & Online & Online \\
\hline 626 & Online & Offline & Offline & Brain & $\begin{array}{l}\text { Non- } \\
\text { digital }\end{array}$ & Digital & Online & Offline \\
\hline 627 & Online & Offline & Offline & Brain & $\begin{array}{l}\text { Non- } \\
\text { digital }\end{array}$ & Digital & Offline & Online \\
\hline 628 & Online & Offline & Offline & Brain & $\begin{array}{l}\text { Non- } \\
\text { digital }\end{array}$ & Digital & Offline & Offline \\
\hline 629 & Online & Offline & Offline & Brain & $\begin{array}{l}\text { Non- } \\
\text { digital }\end{array}$ & Non-digital & Online & Online \\
\hline 630 & Online & Offline & Offline & Brain & $\begin{array}{l}\text { Non- } \\
\text { digital }\end{array}$ & Non-digital & Online & Offline \\
\hline 631 & Online & Offline & Offline & Brain & $\begin{array}{l}\text { Non- } \\
\text { digital }\end{array}$ & Non-digital & Offline & Online \\
\hline 632 & Online & Offline & Offline & Brain & $\begin{array}{l}\text { Non- } \\
\text { digital }\end{array}$ & Non-digital & Offline & Offline \\
\hline 633 & Online & Offline & Offline & Brain & $\begin{array}{l}\text { Non- } \\
\text { digital }\end{array}$ & Blended & Online & Online \\
\hline 634 & Online & Offline & Offline & Brain & $\begin{array}{l}\text { Non- } \\
\text { digital }\end{array}$ & Blended & Online & Offline \\
\hline 635 & Online & Offline & Offline & Brain & $\begin{array}{l}\text { Non- } \\
\text { digital }\end{array}$ & Blended & Offline & Online \\
\hline 636 & Online & Offline & Offline & Brain & $\begin{array}{l}\text { Non- } \\
\text { digital }\end{array}$ & Blended & Offline & Offline \\
\hline 637 & Online & Offline & Offline & Brain & $\begin{array}{l}\text { Blend- } \\
\text { ed }\end{array}$ & Digital & Online & Online \\
\hline 638 & Online & Offline & Offline & Brain & $\begin{array}{l}\text { Blend- } \\
\text { ed }\end{array}$ & Digital & Online & Offline \\
\hline 639 & Online & Offline & Offline & Brain & $\begin{array}{l}\text { Blend- } \\
\text { ed }\end{array}$ & Digital & Offline & Online \\
\hline 640 & Online & Offline & Offline & Brain & $\begin{array}{l}\text { Blend- } \\
\text { ed }\end{array}$ & Digital & Offline & Offline \\
\hline 641 & Online & Offline & Offline & Brain & $\begin{array}{l}\text { Blend- } \\
\text { ed }\end{array}$ & Non-digital & Online & Online \\
\hline 642 & Online & Offline & Offline & Brain & $\begin{array}{l}\text { Blend- } \\
\text { ed }\end{array}$ & Non-digital & Online & Offline \\
\hline 643 & Online & Offline & Offline & Brain & $\begin{array}{l}\text { Blend- } \\
\text { ed }\end{array}$ & Non-digital & Offline & Online \\
\hline 644 & Online & Offline & Offline & Brain & $\begin{array}{l}\text { Blend- } \\
\text { ed }\end{array}$ & Non-digital & Offline & Offline \\
\hline 645 & Online & Offline & Offline & Brain & $\begin{array}{l}\text { Blend- } \\
\text { ed }\end{array}$ & Blended & Online & Online \\
\hline 646 & Online & Offline & Offline & Brain & $\begin{array}{l}\text { Blend- } \\
\text { ed }\end{array}$ & Blended & Online & Offline \\
\hline 647 & Online & Offline & Offline & Brain & $\begin{array}{l}\text { Blend- } \\
\text { ed }\end{array}$ & Blended & Offline & Online \\
\hline 648 & Online & Offline & Offline & Brain & $\begin{array}{l}\text { Blend- } \\
\text { ed }\end{array}$ & Blended & Offline & Offline \\
\hline 649 & Online & Offline & Offline & Brain $+d+n-d$ & Digital & Digital & Online & Online \\
\hline 650 & Online & Offline & Offline & Brain $+d+n-d$ & Digital & Digital & Online & Offline \\
\hline 651 & Online & Offline & Offline & Brain $+d+n-d$ & Digital & Digital & Offline & Online \\
\hline 652 & Online & Offline & Offline & Brain $+d+n-d$ & Digital & Digital & Offline & Offline \\
\hline 653 & Online & Offline & Offline & Brain $+d+n-d$ & Digital & Non-digital & Online & Online \\
\hline 654 & Online & Offline & Offline & Brain $+d+n-d$ & Digital & Non-digital & Online & Offline \\
\hline 655 & Online & Offline & Offline & Brain $+d+n-d$ & Digital & Non-digital & Offline & Online \\
\hline 656 & Online & Offline & Offline & Brain $+d+n-d$ & Digital & Non-digital & Offline & Offline \\
\hline 657 & Online & Offline & Offline & Brain $+d+n-d$ & Digital & Blended & Online & Online \\
\hline 658 & Online & Offline & Offline & Brain $+d+n-d$ & Digital & Blended & Online & Offline \\
\hline 659 & Online & Offline & Offline & Brain $+d+n-d$ & Digital & Blended & Offline & Online \\
\hline
\end{tabular}




\begin{tabular}{|c|c|c|c|c|c|c|c|c|}
\hline 660 & Online & Offline & Offline & Brain $+d+n-d$ & Digital & Blended & Offline & Offline \\
\hline 661 & Online & Offline & Offline & Brain $+d+n-d$ & $\begin{array}{l}\text { Non- } \\
\text { digital }\end{array}$ & Digital & Online & Online \\
\hline 662 & Online & Offline & Offline & Brain $+d+n-d$ & $\begin{array}{l}\text { Non- } \\
\text { digital }\end{array}$ & Digital & Online & Offline \\
\hline 663 & Online & Offline & Offline & Brain + d + n-d & $\begin{array}{l}\text { Non- } \\
\text { digital }\end{array}$ & Digital & Offline & Online \\
\hline 664 & Online & Offline & Offline & Brain $+d+n-d$ & $\begin{array}{l}\text { Non- } \\
\text { digital }\end{array}$ & Digital & Offline & Offline \\
\hline 665 & Online & Offline & Offline & Brain $+d+n-d$ & $\begin{array}{l}\text { Non- } \\
\text { digital }\end{array}$ & Non-digital & Online & Online \\
\hline 666 & Online & Offline & Offline & Brain $+d+n-d$ & $\begin{array}{l}\text { Non- } \\
\text { digital }\end{array}$ & Non-digital & Online & Offline \\
\hline 667 & Online & Offline & Offline & Brain $+d+n-d$ & $\begin{array}{l}\text { Non- } \\
\text { digital }\end{array}$ & Non-digital & Offline & Online \\
\hline 668 & Online & Offline & Offline & Brain $+d+n-d$ & $\begin{array}{l}\text { Non- } \\
\text { digital }\end{array}$ & Non-digital & Offline & Offline \\
\hline 669 & Online & Offline & Offline & Brain $+d+n-d$ & $\begin{array}{l}\text { Non- } \\
\text { digital }\end{array}$ & Blended & Online & Online \\
\hline 670 & Online & Offline & Offline & Brain $+d+n-d$ & $\begin{array}{l}\text { Non- } \\
\text { digital }\end{array}$ & Blended & Online & Offline \\
\hline 671 & Online & Offline & Offline & Brain $+d+n-d$ & $\begin{array}{l}\text { Non- } \\
\text { digital }\end{array}$ & Blended & Offline & Online \\
\hline 672 & Online & Offline & Offline & Brain $+d+n-d$ & $\begin{array}{l}\text { Non- } \\
\text { digital }\end{array}$ & Blended & Offline & Offline \\
\hline 673 & Online & Offline & Offline & Brain $+d+n-d$ & $\begin{array}{l}\text { Blend- } \\
\text { ed }\end{array}$ & Digital & Online & Online \\
\hline 674 & Online & Offline & Offline & Brain $+d+n-d$ & $\begin{array}{l}\text { Blend- } \\
\text { ed }\end{array}$ & Digital & Online & Offline \\
\hline 675 & Online & Offline & Offline & Brain $+d+n-d$ & $\begin{array}{l}\text { Blend- } \\
\text { ed }\end{array}$ & Digital & Offline & Online \\
\hline 676 & Online & Offline & Offline & Brain $+d+n-d$ & $\begin{array}{l}\text { Blend- } \\
\text { ed }\end{array}$ & Digital & Offline & Offline \\
\hline 677 & Online & Offline & Offline & Brain $+d+n-d$ & $\begin{array}{l}\text { Blend- } \\
\text { ed }\end{array}$ & Non-digital & Online & Online \\
\hline 678 & Online & Offline & Offline & Brain $+d+n-d$ & $\begin{array}{l}\text { Blend- } \\
\text { ed }\end{array}$ & Non-digital & Online & Offline \\
\hline 679 & Online & Offline & Offline & Brain $+d+n-d$ & $\begin{array}{l}\text { Blend- } \\
\text { ed }\end{array}$ & Non-digital & Offline & Online \\
\hline 680 & Online & Offline & Offline & Brain $+d+n-d$ & $\begin{array}{l}\text { Blend- } \\
\text { ed }\end{array}$ & Non-digital & Offline & Offline \\
\hline 681 & Online & Offline & Offline & Brain $+d+n-d$ & $\begin{array}{l}\text { Blend- } \\
\text { ed }\end{array}$ & Blended & Online & Online \\
\hline 682 & Online & Offline & Offline & Brain $+d+n-d$ & $\begin{array}{l}\text { Blend- } \\
\text { ed }\end{array}$ & Blended & Online & Offline \\
\hline 683 & Online & Offline & Offline & Brain $+d+n-d$ & $\begin{array}{l}\text { Blend- } \\
\text { ed }\end{array}$ & Blended & Offline & Online \\
\hline 684 & Online & Offline & Offline & Brain $+d+n-d$ & $\begin{array}{l}\text { Blend- } \\
\text { ed }\end{array}$ & Blended & Offline & Offline \\
\hline 685 & Online & Offline & Offline & Brain + n-d & Digital & Digital & Online & Online \\
\hline 686 & Online & Offline & Offline & Brain + n-d & Digital & Digital & Online & Offline \\
\hline 687 & Online & Offline & Offline & Brain + n-d & Digital & Digital & Offline & Online \\
\hline 688 & Online & Offline & Offline & Brain + n-d & Digital & Digital & Offline & Offline \\
\hline 689 & Online & Offline & Offline & Brain + n-d & Digital & Non-digital & Online & Online \\
\hline 690 & Online & Offline & Offline & Brain + n-d & Digital & Non-digital & Online & Offline \\
\hline 691 & Online & Offline & Offline & Brain + n-d & Digital & Non-digital & Offline & Online \\
\hline 692 & Online & Offline & Offline & Brain + n-d & Digital & Non-digital & Offline & Offline \\
\hline 693 & Online & Offline & Offline & Brain + n-d & Digital & Blended & Online & Online \\
\hline 694 & Online & Offline & Offline & Brain + n-d & Digital & Blended & Online & Offline \\
\hline 695 & Online & Offline & Offline & Brain + n-d & Digital & Blended & Offline & Online \\
\hline 696 & Online & Offline & Offline & Brain + n-d & Digital & Blended & Offline & Offline \\
\hline 697 & Online & Offline & Offline & Brain + n-d & $\begin{array}{l}\text { Non- } \\
\text { digital }\end{array}$ & Digital & Online & Online \\
\hline 698 & Online & Offline & Offline & Brain + n-d & $\begin{array}{l}\text { Non- } \\
\text { digital }\end{array}$ & Digital & Online & Offline \\
\hline
\end{tabular}




\begin{tabular}{|c|c|c|c|c|c|c|c|c|}
\hline 699 & Online & Offline & Offline & Brain + n-d & $\begin{array}{l}\text { Non- } \\
\text { digital }\end{array}$ & Digital & Offline & Online \\
\hline 700 & Online & Offline & Offline & Brain + n-d & $\begin{array}{l}\text { Non- } \\
\text { digital }\end{array}$ & Digital & Offline & Offline \\
\hline 701 & Online & Offline & Offline & Brain + n-d & $\begin{array}{l}\text { Non- } \\
\text { digital }\end{array}$ & Non-digital & Online & Online \\
\hline 702 & Online & Offline & Offline & Brain + n-d & $\begin{array}{l}\text { Non- } \\
\text { digital }\end{array}$ & Non-digital & Online & Offline \\
\hline 703 & Online & Offline & Offline & Brain + n-d & $\begin{array}{l}\text { Non- } \\
\text { digital }\end{array}$ & Non-digital & Offline & Online \\
\hline 704 & Online & Offline & Offline & Brain + n-d & $\begin{array}{l}\text { Non- } \\
\text { digital }\end{array}$ & Non-digital & Offline & Offline \\
\hline 705 & Online & Offline & Offline & Brain + n-d & $\begin{array}{l}\text { Non- } \\
\text { digital }\end{array}$ & Blended & Online & Online \\
\hline 706 & Online & Offline & Offline & Brain + n-d & $\begin{array}{l}\text { Non- } \\
\text { digital }\end{array}$ & Blended & Online & Offline \\
\hline 707 & Online & Offline & Offline & Brain + n-d & $\begin{array}{l}\text { Non- } \\
\text { digital }\end{array}$ & Blended & Offline & Online \\
\hline 708 & Online & Offline & Offline & Brain + n-d & $\begin{array}{l}\text { Non- } \\
\text { digital }\end{array}$ & Blended & Offline & Offline \\
\hline 709 & Online & Offline & Offline & Brain + n-d & $\begin{array}{l}\text { Blend- } \\
\text { ed }\end{array}$ & Digital & Online & Online \\
\hline 710 & Online & Offline & Offline & Brain + n-d & $\begin{array}{l}\text { Blend- } \\
\text { ed }\end{array}$ & Digital & Online & Offline \\
\hline 711 & Online & Offline & Offline & Brain + n-d & $\begin{array}{l}\text { Blend- } \\
\text { ed }\end{array}$ & Digital & Offline & Online \\
\hline 712 & Online & Offline & Offline & Brain + n-d & $\begin{array}{l}\text { Blend- } \\
\text { ed }\end{array}$ & Digital & Offline & Offline \\
\hline 713 & Online & Offline & Offline & Brain $+n-d$ & $\begin{array}{l}\text { Blend- } \\
\text { ed }\end{array}$ & Non-digital & Online & Online \\
\hline 714 & Online & Offline & Offline & Brain $+n-d$ & $\begin{array}{l}\text { Blend- } \\
\text { ed }\end{array}$ & Non-digital & Online & Offline \\
\hline 715 & Online & Offline & Offline & Brain $+n-d$ & $\begin{array}{l}\text { Blend- } \\
\text { ed }\end{array}$ & Non-digital & Offline & Online \\
\hline 716 & Online & Offline & Offline & Brain + n-d & $\begin{array}{l}\text { Blend- } \\
\text { ed }\end{array}$ & Non-digital & Offline & Offline \\
\hline 717 & Online & Offline & Offline & Brain $+n-d$ & $\begin{array}{l}\text { Blend- } \\
\text { ed }\end{array}$ & Blended & Online & Online \\
\hline 718 & Online & Offline & Offline & Brain $+n-d$ & $\begin{array}{l}\text { Blend- } \\
\text { ed }\end{array}$ & Blended & Online & Offline \\
\hline 719 & Online & Offline & Offline & Brain + n-d & $\begin{array}{l}\text { Blend- } \\
\text { ed }\end{array}$ & Blended & Offline & Online \\
\hline 720 & Online & Offline & Offline & Brain + n-d & $\begin{array}{l}\text { Blend- } \\
\text { ed }\end{array}$ & Blended & Offline & Offline \\
\hline 721 & Online & Offline & Blended & Brain + digital & Digital & Digital & Online & Online \\
\hline 722 & Online & Offline & Blended & Brain + digital & Digital & Digital & Online & Offline \\
\hline 723 & Online & Offline & Blended & Brain + digital & Digital & Digital & Offline & Online \\
\hline 724 & Online & Offline & Blended & Brain + digital & Digital & Digital & Offline & Offline \\
\hline 725 & Online & Offline & Blended & Brain + digital & Digital & Non-digital & Online & Online \\
\hline 726 & Online & Offline & Blended & Brain + digital & Digital & Non-digital & Online & Offline \\
\hline 727 & Online & Offline & Blended & Brain + digital & Digital & Non-digital & Offline & Online \\
\hline 728 & Online & Offline & Blended & Brain + digital & Digital & Non-digital & Offline & Offline \\
\hline 729 & Online & Offline & Blended & Brain + digital & Digital & Blended & Online & Online \\
\hline 730 & Online & Offline & Blended & Brain + digital & Digital & Blended & Online & Offline \\
\hline 731 & Online & Offline & Blended & Brain + digital & Digital & Blended & Offline & Online \\
\hline 732 & Online & Offline & Blended & Brain + digital & Digital & Blended & Offline & Offline \\
\hline 733 & Online & Offline & Blended & Brain + digital & $\begin{array}{l}\text { Non- } \\
\text { digital }\end{array}$ & Digital & Online & Online \\
\hline 734 & Online & Offline & Blended & Brain + digital & $\begin{array}{l}\text { Non- } \\
\text { digital }\end{array}$ & Digital & Online & Offline \\
\hline 735 & Online & Offline & Blended & Brain + digital & $\begin{array}{l}\text { Non- } \\
\text { digital }\end{array}$ & Digital & Offline & Online \\
\hline 736 & Online & Offline & Blended & Brain + digital & $\begin{array}{l}\text { Non- } \\
\text { digital }\end{array}$ & Digital & Offline & Offline \\
\hline
\end{tabular}




\begin{tabular}{|c|c|c|c|c|c|c|c|c|}
\hline 737 & Online & Offline & Blended & Brain + digital & $\begin{array}{l}\text { Non- } \\
\text { digital }\end{array}$ & Non-digital & Online & Online \\
\hline 738 & Online & Offline & Blended & Brain + digital & $\begin{array}{l}\text { Non- } \\
\text { digital }\end{array}$ & Non-digital & Online & Offline \\
\hline 739 & Online & Offline & Blended & Brain + digital & $\begin{array}{l}\text { Non- } \\
\text { digital }\end{array}$ & Non-digital & Offline & Online \\
\hline 740 & Online & Offline & Blended & Brain + digital & $\begin{array}{l}\text { Non- } \\
\text { digital }\end{array}$ & Non-digital & Offline & Offline \\
\hline 741 & Online & Offline & Blended & Brain + digital & $\begin{array}{l}\text { Non- } \\
\text { digital }\end{array}$ & Blended & Online & Online \\
\hline 742 & Online & Offline & Blended & Brain + digital & $\begin{array}{l}\text { Non- } \\
\text { digital }\end{array}$ & Blended & Online & Offline \\
\hline 743 & Online & Offline & Blended & Brain + digital & $\begin{array}{l}\text { Non- } \\
\text { digital }\end{array}$ & Blended & Offline & Online \\
\hline 744 & Online & Offline & Blended & Brain + digital & $\begin{array}{l}\text { Non- } \\
\text { digital }\end{array}$ & Blended & Offline & Offline \\
\hline 745 & Online & Offline & Blended & Brain + digital & $\begin{array}{l}\text { Blend- } \\
\text { ed }\end{array}$ & Digital & Online & Online \\
\hline 746 & Online & Offline & Blended & Brain + digital & $\begin{array}{l}\text { Blend- } \\
\text { ed }\end{array}$ & Digital & Online & Offline \\
\hline 747 & Online & Offline & Blended & Brain + digital & $\begin{array}{l}\text { Blend- } \\
\text { ed }\end{array}$ & Digital & Offline & Online \\
\hline 748 & Online & Offline & Blended & Brain + digital & $\begin{array}{l}\text { Blend- } \\
\text { ed }\end{array}$ & Digital & Offline & Offline \\
\hline 749 & Online & Offline & Blended & Brain + digital & $\begin{array}{l}\text { Blend- } \\
\text { ed }\end{array}$ & Non-digital & Online & Online \\
\hline 750 & Online & Offline & Blended & Brain + digital & $\begin{array}{l}\text { Blend- } \\
\text { ed }\end{array}$ & Non-digital & Online & Offline \\
\hline 751 & Online & Offline & Blended & Brain + digital & $\begin{array}{l}\text { Blend- } \\
\text { ed }\end{array}$ & Non-digital & Offline & Online \\
\hline 752 & Online & Offline & Blended & Brain + digital & $\begin{array}{l}\text { Blend- } \\
\text { ed }\end{array}$ & Non-digital & Offline & Offline \\
\hline 753 & Online & Offline & Blended & Brain + digital & $\begin{array}{l}\text { Blend- } \\
\text { ed }\end{array}$ & Blended & Online & Online \\
\hline 754 & Online & Offline & Blended & Brain + digital & $\begin{array}{l}\text { Blend- } \\
\text { ed }\end{array}$ & Blended & Online & Offline \\
\hline 755 & Online & Offline & Blended & Brain + digital & $\begin{array}{l}\text { Blend- } \\
\text { ed }\end{array}$ & Blended & Offline & Online \\
\hline 756 & Online & Offline & Blended & Brain + digital & $\begin{array}{l}\text { Blend- } \\
\text { ed }\end{array}$ & Blended & Offline & Offline \\
\hline 757 & Online & Offline & Blended & Brain & Digital & Digital & Online & Online \\
\hline 758 & Online & Offline & Blended & Brain & Digital & Digital & Online & Offline \\
\hline 759 & Online & Offline & Blended & Brain & Digital & Digital & Offline & Online \\
\hline 760 & Online & Offline & Blended & Brain & Digital & Digital & Offline & Offline \\
\hline 761 & Online & Offline & Blended & Brain & Digital & Non-digital & Online & Online \\
\hline 762 & Online & Offline & Blended & Brain & Digital & Non-digital & Online & Offline \\
\hline 763 & Online & Offline & Blended & Brain & Digital & Non-digital & Offline & Online \\
\hline 764 & Online & Offline & Blended & Brain & Digital & Non-digital & Offline & Offline \\
\hline 765 & Online & Offline & Blended & Brain & Digital & Blended & Online & Online \\
\hline 766 & Online & Offline & Blended & Brain & Digital & Blended & Online & Offline \\
\hline 767 & Online & Offline & Blended & Brain & Digital & Blended & Offline & Online \\
\hline 768 & Online & Offline & Blended & Brain & Digital & Blended & Offline & Offline \\
\hline 769 & Online & Offline & Blended & Brain & $\begin{array}{l}\text { Non- } \\
\text { digital }\end{array}$ & Digital & Online & Online \\
\hline 770 & Online & Offline & Blended & Brain & $\begin{array}{l}\text { Non- } \\
\text { digital }\end{array}$ & Digital & Online & Offline \\
\hline 771 & Online & Offline & Blended & Brain & $\begin{array}{l}\text { Non- } \\
\text { digital }\end{array}$ & Digital & Offline & Online \\
\hline 772 & Online & Offline & Blended & Brain & $\begin{array}{l}\text { Non- } \\
\text { digital }\end{array}$ & Digital & Offline & Offline \\
\hline 773 & Online & Offline & Blended & Brain & $\begin{array}{l}\text { Non- } \\
\text { digital }\end{array}$ & Non-digital & Online & Online \\
\hline 774 & Online & Offline & Blended & Brain & $\begin{array}{l}\text { Non- } \\
\text { digital }\end{array}$ & Non-digital & Online & Offline \\
\hline
\end{tabular}




\begin{tabular}{|c|c|c|c|c|c|c|c|c|}
\hline 775 & Online & Offline & Blended & Brain & $\begin{array}{l}\text { Non- } \\
\text { digital }\end{array}$ & Non-digital & Offline & Online \\
\hline 776 & Online & Offline & Blended & Brain & $\begin{array}{l}\text { Non- } \\
\text { digital }\end{array}$ & Non-digital & Offline & Offline \\
\hline 777 & Online & Offline & Blended & Brain & $\begin{array}{l}\text { Non- } \\
\text { digital }\end{array}$ & Blended & Online & Online \\
\hline 778 & Online & Offline & Blended & Brain & $\begin{array}{l}\text { Non- } \\
\text { digital }\end{array}$ & Blended & Online & Offline \\
\hline 779 & Online & Offline & Blended & Brain & $\begin{array}{l}\text { Non- } \\
\text { digital }\end{array}$ & Blended & Offline & Online \\
\hline 780 & Online & Offline & Blended & Brain & $\begin{array}{l}\text { Non- } \\
\text { digital }\end{array}$ & Blended & Offline & Offline \\
\hline 781 & Online & Offline & Blended & Brain & $\begin{array}{l}\text { Blend- } \\
\text { ed }\end{array}$ & Digital & Online & Online \\
\hline 782 & Online & Offline & Blended & Brain & $\begin{array}{l}\text { Blend- } \\
\text { ed }\end{array}$ & Digital & Online & Offline \\
\hline 783 & Online & Offline & Blended & Brain & $\begin{array}{l}\text { Blend- } \\
\text { ed }\end{array}$ & Digital & Offline & Online \\
\hline 784 & Online & Offline & Blended & Brain & $\begin{array}{l}\text { Blend- } \\
\text { ed }\end{array}$ & Digital & Offline & Offline \\
\hline 785 & Online & Offline & Blended & Brain & $\begin{array}{l}\text { Blend- } \\
\text { ed }\end{array}$ & Non-digital & Online & Online \\
\hline 786 & Online & Offline & Blended & Brain & $\begin{array}{l}\text { Blend- } \\
\text { ed }\end{array}$ & Non-digital & Online & Offline \\
\hline 787 & Online & Offline & Blended & Brain & $\begin{array}{l}\text { Blend- } \\
\text { ed }\end{array}$ & Non-digital & Offline & Online \\
\hline 788 & Online & Offline & Blended & Brain & $\begin{array}{l}\text { Blend- } \\
\text { ed }\end{array}$ & Non-digital & Offline & Offline \\
\hline 789 & Online & Offline & Blended & Brain & $\begin{array}{l}\text { Blend- } \\
\text { ed }\end{array}$ & Blended & Online & Online \\
\hline 790 & Online & Offline & Blended & Brain & $\begin{array}{l}\text { Blend- } \\
\text { ed }\end{array}$ & Blended & Online & Offline \\
\hline 791 & Online & Offline & Blended & Brain & $\begin{array}{l}\text { Blend- } \\
\text { ed }\end{array}$ & Blended & Offline & Online \\
\hline 792 & Online & Offline & Blended & Brain & $\begin{array}{l}\text { Blend- } \\
\text { ed }\end{array}$ & Blended & Offline & Offline \\
\hline 793 & Online & Offline & Blended & Brain $+d+n-d$ & Digital & Digital & Online & Online \\
\hline 794 & Online & Offline & Blended & Brain $+d+n-d$ & Digital & Digital & Online & Offline \\
\hline 795 & Online & Offline & Blended & Brain $+d+n-d$ & Digital & Digital & Offline & Online \\
\hline 796 & Online & Offline & Blended & Brain $+d+n-d$ & Digital & Digital & Offline & Offline \\
\hline 797 & Online & Offline & Blended & Brain $+d+n-d$ & Digital & Non-digital & Online & Online \\
\hline 798 & Online & Offline & Blended & Brain $+d+n-d$ & Digital & Non-digital & Online & Offline \\
\hline 799 & Online & Offline & Blended & Brain $+d+n-d$ & Digital & Non-digital & Offline & Online \\
\hline 800 & Online & Offline & Blended & Brain $+d+n-d$ & Digital & Non-digital & Offline & Offline \\
\hline 801 & Online & Offline & Blended & Brain $+d+n-d$ & Digital & Blended & Online & Online \\
\hline 802 & Online & Offline & Blended & Brain $+d+n-d$ & Digital & Blended & Online & Offline \\
\hline 803 & Online & Offline & Blended & Brain $+d+n-d$ & Digital & Blended & Offline & Online \\
\hline 804 & Online & Offline & Blended & Brain $+d+n-d$ & Digital & Blended & Offline & Offline \\
\hline 805 & Online & Offline & Blended & Brain $+d+n-d$ & $\begin{array}{l}\text { Non- } \\
\text { digital }\end{array}$ & Digital & Online & Online \\
\hline 806 & Online & Offline & Blended & Brain $+d+n-d$ & $\begin{array}{l}\text { Non- } \\
\text { digital }\end{array}$ & Digital & Online & Offline \\
\hline 807 & Online & Offline & Blended & Brain $+d+n-d$ & $\begin{array}{l}\text { Non- } \\
\text { digital }\end{array}$ & Digital & Offline & Online \\
\hline 808 & Online & Offline & Blended & Brain $+d+n-d$ & $\begin{array}{l}\text { Non- } \\
\text { digital }\end{array}$ & Digital & Offline & Offline \\
\hline 809 & Online & Offline & Blended & Brain $+d+n-d$ & $\begin{array}{l}\text { Non- } \\
\text { digital }\end{array}$ & Non-digital & Online & Online \\
\hline 810 & Online & Offline & Blended & Brain $+d+n-d$ & $\begin{array}{l}\text { Non- } \\
\text { digital }\end{array}$ & Non-digital & Online & Offline \\
\hline 811 & Online & Offline & Blended & Brain $+d+n-d$ & $\begin{array}{l}\text { Non- } \\
\text { digital }\end{array}$ & Non-digital & Offline & Online \\
\hline 812 & Online & Offline & Blended & Brain $+d+n-d$ & $\begin{array}{l}\text { Non- } \\
\text { digital }\end{array}$ & Non-digital & Offline & Offline \\
\hline
\end{tabular}




\begin{tabular}{|c|c|c|c|c|c|c|c|c|}
\hline 813 & Online & Offline & Blended & Brain $+d+n-d$ & $\begin{array}{l}\text { Non- } \\
\text { digital }\end{array}$ & Blended & Online & Online \\
\hline 814 & Online & Offline & Blended & Brain $+d+n-d$ & $\begin{array}{l}\text { Non- } \\
\text { digital }\end{array}$ & Blended & Online & Offline \\
\hline 815 & Online & Offline & Blended & Brain $+d+n-d$ & $\begin{array}{l}\text { Non- } \\
\text { digital }\end{array}$ & Blended & Offline & Online \\
\hline 816 & Online & Offline & Blended & Brain $+d+n-d$ & $\begin{array}{l}\text { Non- } \\
\text { digital }\end{array}$ & Blended & Offline & Offline \\
\hline 817 & Online & Offline & Blended & Brain $+d+n-d$ & $\begin{array}{l}\text { Blend- } \\
\text { ed }\end{array}$ & Digital & Online & Online \\
\hline 818 & Online & Offline & Blended & Brain $+d+n-d$ & $\begin{array}{l}\text { Blend- } \\
\text { ed }\end{array}$ & Digital & Online & Offline \\
\hline 819 & Online & Offline & Blended & Brain $+d+n-d$ & $\begin{array}{l}\text { Blend- } \\
\text { ed }\end{array}$ & Digital & Offline & Online \\
\hline 820 & Online & Offline & Blended & Brain $+d+n-d$ & $\begin{array}{l}\text { Blend- } \\
\text { ed }\end{array}$ & Digital & Offline & Offline \\
\hline 821 & Online & Offline & Blended & Brain $+d+n-d$ & $\begin{array}{l}\text { Blend- } \\
\text { ed }\end{array}$ & Non-digital & Online & Online \\
\hline 822 & Online & Offline & Blended & Brain $+d+n-d$ & $\begin{array}{l}\text { Blend- } \\
\text { ed }\end{array}$ & Non-digital & Online & Offline \\
\hline 823 & Online & Offline & Blended & Brain $+d+n-d$ & $\begin{array}{l}\text { Blend- } \\
\text { ed }\end{array}$ & Non-digital & Offline & Online \\
\hline 824 & Online & Offline & Blended & Brain $+d+n-d$ & $\begin{array}{l}\text { Blend- } \\
\text { ed }\end{array}$ & Non-digital & Offline & Offline \\
\hline 825 & Online & Offline & Blended & Brain $+d+n-d$ & $\begin{array}{l}\text { Blend- } \\
\text { ed }\end{array}$ & Blended & Online & Online \\
\hline 826 & Online & Offline & Blended & Brain $+d+n-d$ & $\begin{array}{l}\text { Blend- } \\
\text { ed }\end{array}$ & Blended & Online & Offline \\
\hline 827 & Online & Offline & Blended & Brain $+d+n-d$ & $\begin{array}{l}\text { Blend- } \\
\text { ed }\end{array}$ & Blended & Offline & Online \\
\hline 828 & Online & Offline & Blended & Brain $+d+n-d$ & $\begin{array}{l}\text { Blend- } \\
\text { ed }\end{array}$ & Blended & Offline & Offline \\
\hline 829 & Online & Offline & Blended & Brain + n-d & Digital & Digital & Online & Online \\
\hline 830 & Online & Offline & Blended & Brain + n-d & Digital & Digital & Online & Offline \\
\hline 831 & Online & Offline & Blended & Brain + n-d & Digital & Digital & Offline & Online \\
\hline 832 & Online & Offline & Blended & Brain + n-d & Digital & Digital & Offline & Offline \\
\hline 833 & Online & Offline & Blended & Brain + n-d & Digital & Non-digital & Online & Online \\
\hline 834 & Online & Offline & Blended & Brain + n-d & Digital & Non-digital & Online & Offline \\
\hline 835 & Online & Offline & Blended & Brain + n-d & Digital & Non-digital & Offline & Online \\
\hline 836 & Online & Offline & Blended & Brain + n-d & Digital & Non-digital & Offline & Offline \\
\hline 837 & Online & Offline & Blended & Brain + n-d & Digital & Blended & Online & Online \\
\hline 838 & Online & Offline & Blended & Brain + n-d & Digital & Blended & Online & Offline \\
\hline 839 & Online & Offline & Blended & Brain + n-d & Digital & Blended & Offline & Online \\
\hline 840 & Online & Offline & Blended & Brain + n-d & Digital & Blended & Offline & Offline \\
\hline 841 & Online & Offline & Blended & Brain + n-d & $\begin{array}{l}\text { Non- } \\
\text { digital }\end{array}$ & Digital & Online & Online \\
\hline 842 & Online & Offline & Blended & Brain + n-d & $\begin{array}{l}\text { Non- } \\
\text { digital }\end{array}$ & Digital & Online & Offline \\
\hline 843 & Online & Offline & Blended & Brain + n-d & $\begin{array}{l}\text { Non- } \\
\text { digital }\end{array}$ & Digital & Offline & Online \\
\hline 844 & Online & Offline & Blended & Brain + n-d & $\begin{array}{l}\text { Non- } \\
\text { digital }\end{array}$ & Digital & Offline & Offline \\
\hline 845 & Online & Offline & Blended & Brain + n-d & $\begin{array}{l}\text { Non- } \\
\text { digital }\end{array}$ & Non-digital & Online & Online \\
\hline 846 & Online & Offline & Blended & Brain + n-d & $\begin{array}{l}\text { Non- } \\
\text { digital }\end{array}$ & Non-digital & Online & Offline \\
\hline 847 & Online & Offline & Blended & Brain + n-d & $\begin{array}{l}\text { Non- } \\
\text { digital }\end{array}$ & Non-digital & Offline & Online \\
\hline 848 & Online & Offline & Blended & Brain + n-d & $\begin{array}{l}\text { Non- } \\
\text { digital }\end{array}$ & Non-digital & Offline & Offline \\
\hline 849 & Online & Offline & Blended & Brain + n-d & $\begin{array}{l}\text { Non- } \\
\text { digital }\end{array}$ & Blended & Online & Online \\
\hline 850 & Online & Offline & Blended & Brain + n-d & $\begin{array}{l}\text { Non- } \\
\text { digital }\end{array}$ & Blended & Online & Offline \\
\hline
\end{tabular}




\begin{tabular}{|c|c|c|c|c|c|c|c|c|}
\hline 851 & Online & Offline & Blended & Brain + n-d & $\begin{array}{l}\text { Non- } \\
\text { digital }\end{array}$ & Blended & Offline & Online \\
\hline 852 & Online & Offline & Blended & Brain + n-d & $\begin{array}{l}\text { Non- } \\
\text { digital }\end{array}$ & Blended & Offline & Offline \\
\hline 853 & Online & Offline & Blended & Brain $+n-d$ & $\begin{array}{l}\text { Blend- } \\
\text { ed }\end{array}$ & Digital & Online & Online \\
\hline 854 & Online & Offline & Blended & Brain + n-d & $\begin{array}{l}\text { Blend- } \\
\text { ed }\end{array}$ & Digital & Online & Offline \\
\hline 855 & Online & Offline & Blended & Brain + n-d & $\begin{array}{l}\text { Blend- } \\
\text { ed }\end{array}$ & Digital & Offline & Online \\
\hline 856 & Online & Offline & Blended & Brain + n-d & $\begin{array}{l}\text { Blend- } \\
\text { ed }\end{array}$ & Digital & Offline & Offline \\
\hline 857 & Online & Offline & Blended & Brain $+n-d$ & $\begin{array}{l}\text { Blend- } \\
\text { ed }\end{array}$ & Non-digital & Online & Online \\
\hline 858 & Online & Offline & Blended & Brain + n-d & $\begin{array}{l}\text { Blend- } \\
\text { ed }\end{array}$ & Non-digital & Online & Offline \\
\hline 859 & Online & Offline & Blended & Brain + n-d & $\begin{array}{l}\text { Blend- } \\
\text { ed }\end{array}$ & Non-digital & Offline & Online \\
\hline 860 & Online & Offline & Blended & Brain + n-d & $\begin{array}{l}\text { Blend- } \\
\text { ed }\end{array}$ & Non-digital & Offline & Offline \\
\hline 861 & Online & Offline & Blended & Brain $+n-d$ & $\begin{array}{l}\text { Blend- } \\
\text { ed }\end{array}$ & Blended & Online & Online \\
\hline 862 & Online & Offline & Blended & Brain $+n-d$ & $\begin{array}{l}\text { Blend- } \\
\text { ed }\end{array}$ & Blended & Online & Offline \\
\hline 863 & Online & Offline & Blended & Brain + n-d & $\begin{array}{l}\text { Blend- } \\
\text { ed }\end{array}$ & Blended & Offline & Online \\
\hline 864 & Online & Offline & Blended & Brain + n-d & $\begin{array}{l}\text { Blend- } \\
\text { ed }\end{array}$ & Blended & Offline & Offline \\
\hline 865 & Offline & Online & Online & Brain + digital & Digital & Digital & Online & Online \\
\hline 866 & Offline & Online & Online & Brain + digital & Digital & Digital & Online & Offline \\
\hline 867 & Offline & Online & Online & Brain + digital & Digital & Digital & Offline & Online \\
\hline 868 & Offline & Online & Online & Brain + digital & Digital & Digital & Offline & Offline \\
\hline 869 & Offline & Online & Online & Brain + digital & Digital & Non-digital & Online & Online \\
\hline 870 & Offline & Online & Online & Brain + digital & Digital & Non-digital & Online & Offline \\
\hline 871 & Offline & Online & Online & Brain + digital & Digital & Non-digital & Offline & Online \\
\hline 872 & Offline & Online & Online & Brain + digital & Digital & Non-digital & Offline & Offline \\
\hline 873 & Offline & Online & Online & Brain + digital & Digital & Blended & Online & Online \\
\hline 874 & Offline & Online & Online & Brain + digital & Digital & Blended & Online & Offline \\
\hline 875 & Offline & Online & Online & Brain + digital & Digital & Blended & Offline & Online \\
\hline 876 & Offline & Online & Online & Brain + digital & Digital & Blended & Offline & Offline \\
\hline 877 & Offline & Online & Online & Brain + digital & $\begin{array}{l}\text { Non- } \\
\text { digital }\end{array}$ & Digital & Online & Online \\
\hline 878 & Offline & Online & Online & Brain + digital & $\begin{array}{l}\text { Non- } \\
\text { digital }\end{array}$ & Digital & Online & Offline \\
\hline 879 & Offline & Online & Online & Brain + digital & $\begin{array}{l}\text { Non- } \\
\text { digital }\end{array}$ & Digital & Offline & Online \\
\hline 880 & Offline & Online & Online & Brain + digital & $\begin{array}{l}\text { Non- } \\
\text { digital }\end{array}$ & Digital & Offline & Offline \\
\hline 881 & Offline & Online & Online & Brain + digital & $\begin{array}{l}\text { Non- } \\
\text { digital }\end{array}$ & Non-digital & Online & Online \\
\hline 882 & Offline & Online & Online & Brain + digital & $\begin{array}{l}\text { Non- } \\
\text { digital }\end{array}$ & Non-digital & Online & Offline \\
\hline 883 & Offline & Online & Online & Brain + digital & $\begin{array}{l}\text { Non- } \\
\text { digital }\end{array}$ & Non-digital & Offline & Online \\
\hline 884 & Offline & Online & Online & Brain + digital & $\begin{array}{l}\text { Non- } \\
\text { digital }\end{array}$ & Non-digital & Offline & Offline \\
\hline 885 & Offline & Online & Online & Brain + digital & $\begin{array}{l}\text { Non- } \\
\text { digital }\end{array}$ & Blended & Online & Online \\
\hline 886 & Offline & Online & Online & Brain + digital & $\begin{array}{l}\text { Non- } \\
\text { digital }\end{array}$ & Blended & Online & Offline \\
\hline 887 & Offline & Online & Online & Brain + digital & $\begin{array}{l}\text { Non- } \\
\text { digital }\end{array}$ & Blended & Offline & Online \\
\hline 888 & Offline & Online & Online & Brain + digital & $\begin{array}{l}\text { Non- } \\
\text { digital }\end{array}$ & Blended & Offline & Offline \\
\hline
\end{tabular}




\begin{tabular}{|c|c|c|c|c|c|c|c|c|}
\hline 889 & Offline & Online & Online & Brain + digital & $\begin{array}{l}\text { Blend- } \\
\text { ed }\end{array}$ & Digital & Online & Online \\
\hline 890 & Offline & Online & Online & Brain + digital & $\begin{array}{l}\text { Blend- } \\
\text { ed }\end{array}$ & Digital & Online & Offline \\
\hline 891 & Offline & Online & Online & Brain + digital & $\begin{array}{l}\text { Blend- } \\
\text { ed }\end{array}$ & Digital & Offline & Online \\
\hline 892 & Offline & Online & Online & Brain + digital & $\begin{array}{l}\text { Blend- } \\
\text { ed }\end{array}$ & Digital & Offline & Offline \\
\hline 893 & Offline & Online & Online & Brain + digital & $\begin{array}{l}\text { Blend- } \\
\text { ed }\end{array}$ & Non-digital & Online & Online \\
\hline 894 & Offline & Online & Online & Brain + digital & $\begin{array}{l}\text { Blend- } \\
\text { ed }\end{array}$ & Non-digital & Online & Offline \\
\hline 895 & Offline & Online & Online & Brain + digital & $\begin{array}{l}\text { Blend- } \\
\text { ed }\end{array}$ & Non-digital & Offline & Online \\
\hline 896 & Offline & Online & Online & Brain + digital & $\begin{array}{l}\text { Blend- } \\
\text { ed }\end{array}$ & Non-digital & Offline & Offline \\
\hline 897 & Offline & Online & Online & Brain + digital & $\begin{array}{l}\text { Blend- } \\
\text { ed }\end{array}$ & Blended & Online & Online \\
\hline 898 & Offline & Online & Online & Brain + digital & $\begin{array}{l}\text { Blend- } \\
\text { ed }\end{array}$ & Blended & Online & Offline \\
\hline 899 & Offline & Online & Online & Brain + digital & $\begin{array}{l}\text { Blend- } \\
\text { ed }\end{array}$ & Blended & Offline & Online \\
\hline 900 & Offline & Online & Online & Brain + digital & $\begin{array}{l}\text { Blend- } \\
\text { ed }\end{array}$ & Blended & Offline & Offline \\
\hline 901 & Offline & Online & Online & Brain & Digital & Digital & Online & Online \\
\hline 902 & Offline & Online & Online & Brain & Digital & Digital & Online & Offline \\
\hline 903 & Offline & Online & Online & Brain & Digital & Digital & Offline & Online \\
\hline 904 & Offline & Online & Online & Brain & Digital & Digital & Offline & Offline \\
\hline 905 & Offline & Online & Online & Brain & Digital & Non-digital & Online & Online \\
\hline 906 & Offline & Online & Online & Brain & Digital & Non-digital & Online & Offline \\
\hline 907 & Offline & Online & Online & Brain & Digital & Non-digital & Offline & Online \\
\hline 908 & Offline & Online & Online & Brain & Digital & Non-digital & Offline & Offline \\
\hline 909 & Offline & Online & Online & Brain & Digital & Blended & Online & Online \\
\hline 910 & Offline & Online & Online & Brain & Digital & Blended & Online & Offline \\
\hline 911 & Offline & Online & Online & Brain & Digital & Blended & Offline & Online \\
\hline 912 & Offline & Online & Online & Brain & Digital & Blended & Offline & Offline \\
\hline 913 & Offline & Online & Online & Brain & $\begin{array}{l}\text { Non- } \\
\text { digital }\end{array}$ & Digital & Online & Online \\
\hline 914 & Offline & Online & Online & Brain & $\begin{array}{l}\text { Non- } \\
\text { digital }\end{array}$ & Digital & Online & Offline \\
\hline 915 & Offline & Online & Online & Brain & $\begin{array}{l}\text { Non- } \\
\text { digital }\end{array}$ & Digital & Offline & Online \\
\hline 916 & Offline & Online & Online & Brain & $\begin{array}{l}\text { Non- } \\
\text { digital }\end{array}$ & Digital & Offline & Offline \\
\hline 917 & Offline & Online & Online & Brain & $\begin{array}{l}\text { Non- } \\
\text { digital }\end{array}$ & Non-digital & Online & Online \\
\hline 918 & Offline & Online & Online & Brain & $\begin{array}{l}\text { Non- } \\
\text { digital }\end{array}$ & Non-digital & Online & Offline \\
\hline 919 & Offline & Online & Online & Brain & $\begin{array}{l}\text { Non- } \\
\text { digital }\end{array}$ & Non-digital & Offline & Online \\
\hline 920 & Offline & Online & Online & Brain & $\begin{array}{l}\text { Non- } \\
\text { digital }\end{array}$ & Non-digital & Offline & Offline \\
\hline 921 & Offline & Online & Online & Brain & $\begin{array}{l}\text { Non- } \\
\text { digital }\end{array}$ & Blended & Online & Online \\
\hline 922 & Offline & Online & Online & Brain & $\begin{array}{l}\text { Non- } \\
\text { digital }\end{array}$ & Blended & Online & Offline \\
\hline 923 & Offline & Online & Online & Brain & $\begin{array}{l}\text { Non- } \\
\text { digital }\end{array}$ & Blended & Offline & Online \\
\hline 924 & Offline & Online & Online & Brain & $\begin{array}{l}\text { Non- } \\
\text { digital }\end{array}$ & Blended & Offline & Offline \\
\hline 925 & Offline & Online & Online & Brain & $\begin{array}{l}\text { Blend- } \\
\text { ed }\end{array}$ & Digital & Online & Online \\
\hline 926 & Offline & Online & Online & Brain & $\begin{array}{l}\text { Blend- } \\
\text { ed }\end{array}$ & Digital & Online & Offline \\
\hline
\end{tabular}




\begin{tabular}{|c|c|c|c|c|c|c|c|c|}
\hline 927 & Offline & Online & Online & Brain & $\begin{array}{l}\text { Blend- } \\
\text { ed }\end{array}$ & Digital & Offline & Online \\
\hline 928 & Offline & Online & Online & Brain & $\begin{array}{l}\text { Blend- } \\
\text { ed }\end{array}$ & Digital & Offline & Offline \\
\hline 929 & Offline & Online & Online & Brain & $\begin{array}{l}\text { Blend- } \\
\text { ed }\end{array}$ & Non-digital & Online & Online \\
\hline 930 & Offline & Online & Online & Brain & $\begin{array}{l}\text { Blend- } \\
\text { ed }\end{array}$ & Non-digital & Online & Offline \\
\hline 931 & Offline & Online & Online & Brain & $\begin{array}{l}\text { Blend- } \\
\text { ed }\end{array}$ & Non-digital & Offline & Online \\
\hline 932 & Offline & Online & Online & Brain & $\begin{array}{l}\text { Blend- } \\
\text { ed }\end{array}$ & Non-digital & Offline & Offline \\
\hline 933 & Offline & Online & Online & Brain & $\begin{array}{l}\text { Blend- } \\
\text { ed }\end{array}$ & Blended & Online & Online \\
\hline 934 & Offline & Online & Online & Brain & $\begin{array}{l}\text { Blend- } \\
\text { ed }\end{array}$ & Blended & Online & Offline \\
\hline 935 & Offline & Online & Online & Brain & $\begin{array}{l}\text { Blend- } \\
\text { ed }\end{array}$ & Blended & Offline & Online \\
\hline 936 & Offline & Online & Online & Brain & $\begin{array}{l}\text { Blend- } \\
\text { ed }\end{array}$ & Blended & Offline & Offline \\
\hline 937 & Offline & Online & Online & Brain $+d+n-d$ & Digital & Digital & Online & Online \\
\hline 938 & Offline & Online & Online & Brain $+d+n-d$ & Digital & Digital & Online & Offline \\
\hline 939 & Offline & Online & Online & Brain $+d+n-d$ & Digital & Digital & Offline & Online \\
\hline 940 & Offline & Online & Online & Brain $+d+n-d$ & Digital & Digital & Offline & Offline \\
\hline 941 & Offline & Online & Online & Brain $+d+n-d$ & Digital & Non-digital & Online & Online \\
\hline 942 & Offline & Online & Online & Brain $+d+n-d$ & Digital & Non-digital & Online & Offline \\
\hline 943 & Offline & Online & Online & Brain $+d+n-d$ & Digital & Non-digital & Offline & Online \\
\hline 944 & Offline & Online & Online & Brain $+d+n-d$ & Digital & Non-digital & Offline & Offline \\
\hline 945 & Offline & Online & Online & Brain $+d+n-d$ & Digital & Blended & Online & Online \\
\hline 946 & Offline & Online & Online & Brain $+d+n-d$ & Digital & Blended & Online & Offline \\
\hline 947 & Offline & Online & Online & Brain $+d+n-d$ & Digital & Blended & Offline & Online \\
\hline 948 & Offline & Online & Online & Brain $+d+n-d$ & Digital & Blended & Offline & Offline \\
\hline 949 & Offline & Online & Online & Brain $+d+n-d$ & $\begin{array}{l}\text { Non- } \\
\text { digital }\end{array}$ & Digital & Online & Online \\
\hline 950 & Offline & Online & Online & Brain $+d+n-d$ & $\begin{array}{l}\text { Non- } \\
\text { digital }\end{array}$ & Digital & Online & Offline \\
\hline 951 & Offline & Online & Online & Brain $+d+n-d$ & $\begin{array}{l}\text { Non- } \\
\text { digital }\end{array}$ & Digital & Offline & Online \\
\hline 952 & Offline & Online & Online & Brain $+d+n-d$ & $\begin{array}{l}\text { Non- } \\
\text { digital }\end{array}$ & Digital & Offline & Offline \\
\hline 953 & Offline & Online & Online & Brain $+d+n-d$ & $\begin{array}{l}\text { Non- } \\
\text { digital }\end{array}$ & Non-digital & Online & Online \\
\hline 954 & Offline & Online & Online & Brain $+d+n-d$ & $\begin{array}{l}\text { Non- } \\
\text { diqital }\end{array}$ & Non-digital & Online & Offline \\
\hline 955 & Offline & Online & Online & Brain $+d+n-d$ & $\begin{array}{l}\text { Non- } \\
\text { digital }\end{array}$ & Non-digital & Offline & Online \\
\hline 956 & Offline & Online & Online & Brain $+d+n-d$ & $\begin{array}{l}\text { Non- } \\
\text { diqital }\end{array}$ & Non-digital & Offline & Offline \\
\hline 957 & Offline & Online & Online & Brain $+d+n-d$ & $\begin{array}{l}\text { Non- } \\
\text { diqital }\end{array}$ & Blended & Online & Online \\
\hline 958 & Offline & Online & Online & Brain $+d+n-d$ & $\begin{array}{l}\text { Non- } \\
\text { diqital }\end{array}$ & Blended & Online & Offline \\
\hline 959 & Offline & Online & Online & Brain $+d+n-d$ & $\begin{array}{l}\text { Non- } \\
\text { digital }\end{array}$ & Blended & Offline & Online \\
\hline 960 & Offline & Online & Online & Brain $+d+n-d$ & $\begin{array}{l}\text { Non- } \\
\text { diqital }\end{array}$ & Blended & Offline & Offline \\
\hline 961 & Offline & Online & Online & Brain $+d+n-d$ & $\begin{array}{l}\text { Blend- } \\
\text { ed }\end{array}$ & Digital & Online & Online \\
\hline 962 & Offline & Online & Online & Brain $+d+n-d$ & $\begin{array}{l}\text { Blend- } \\
\text { ed }\end{array}$ & Digital & Online & Offline \\
\hline 963 & Offline & Online & Online & Brain $+d+n-d$ & $\begin{array}{l}\text { Blend- } \\
\text { ed }\end{array}$ & Digital & Offline & Online \\
\hline 964 & Offline & Online & Online & Brain $+d+n-d$ & $\begin{array}{l}\text { Blend- } \\
\text { ed }\end{array}$ & Digital & Offline & Offline \\
\hline
\end{tabular}




\begin{tabular}{|c|c|c|c|c|c|c|c|c|}
\hline 965 & Offline & Online & Online & Brain $+d+n-d$ & $\begin{array}{l}\text { Blend- } \\
\text { ed }\end{array}$ & Non-digital & Online & Online \\
\hline 966 & Offline & Online & Online & Brain $+d+n-d$ & $\begin{array}{l}\text { Blend- } \\
\text { ed }\end{array}$ & Non-digital & Online & Offline \\
\hline 967 & Offline & Online & Online & Brain $+d+n-d$ & $\begin{array}{l}\text { Blend- } \\
\text { ed }\end{array}$ & Non-digital & Offline & Online \\
\hline 968 & Offline & Online & Online & Brain $+d+n-d$ & $\begin{array}{l}\text { Blend- } \\
\text { ed }\end{array}$ & Non-digital & Offline & Offline \\
\hline 969 & Offline & Online & Online & Brain $+d+n-d$ & $\begin{array}{l}\text { Blend- } \\
\text { ed }\end{array}$ & Blended & Online & Online \\
\hline 970 & Offline & Online & Online & Brain $+d+n-d$ & $\begin{array}{l}\text { Blend- } \\
\text { ed }\end{array}$ & Blended & Online & Offline \\
\hline 971 & Offline & Online & Online & Brain $+d+n-d$ & $\begin{array}{l}\text { Blend- } \\
\text { ed }\end{array}$ & Blended & Offline & Online \\
\hline 972 & Offline & Online & Online & Brain $+d+n-d$ & $\begin{array}{l}\text { Blend- } \\
\text { ed }\end{array}$ & Blended & Offline & Offline \\
\hline 973 & Offline & Online & Online & Brain + n-d & Digital & Digital & Online & Online \\
\hline 974 & Offline & Online & Online & Brain + n-d & Digital & Digital & Online & Offline \\
\hline 975 & Offline & Online & Online & Brain + n-d & Digital & Digital & Offline & Online \\
\hline 976 & Offline & Online & Online & Brain + n-d & Digital & Digital & Offline & Offline \\
\hline 977 & Offline & Online & Online & Brain + n-d & Digital & Non-digital & Online & Online \\
\hline 978 & Offline & Online & Online & Brain + n-d & Digital & Non-digital & Online & Offline \\
\hline 979 & Offline & Online & Online & Brain + n-d & Digital & Non-digital & Offline & Online \\
\hline 980 & Offline & Online & Online & Brain + n-d & Digital & Non-digital & Offline & Offline \\
\hline 981 & Offline & Online & Online & Brain + n-d & Digital & Blended & Online & Online \\
\hline 982 & Offline & Online & Online & Brain + n-d & Digital & Blended & Online & Offline \\
\hline 983 & Offline & Online & Online & Brain + n-d & Digital & Blended & Offline & Online \\
\hline 984 & Offline & Online & Online & Brain + n-d & Digital & Blended & Offline & Offline \\
\hline 985 & Offline & Online & Online & Brain + n-d & $\begin{array}{l}\text { Non- } \\
\text { digital }\end{array}$ & Digital & Online & Online \\
\hline 986 & Offline & Online & Online & Brain + n-d & $\begin{array}{l}\text { Non- } \\
\text { digital }\end{array}$ & Digital & Online & Offline \\
\hline 987 & Offline & Online & Online & Brain + n-d & $\begin{array}{l}\text { Non- } \\
\text { digital }\end{array}$ & Digital & Offline & Online \\
\hline 988 & Offline & Online & Online & Brain + n-d & $\begin{array}{l}\text { Non- } \\
\text { digital }\end{array}$ & Digital & Offline & Offline \\
\hline 989 & Offline & Online & Online & Brain + n-d & $\begin{array}{l}\text { Non- } \\
\text { digital }\end{array}$ & Non-digital & Online & Online \\
\hline 990 & Offline & Online & Online & Brain + n-d & $\begin{array}{l}\text { Non- } \\
\text { digital }\end{array}$ & Non-digital & Online & Offline \\
\hline 991 & Offline & Online & Online & Brain + n-d & $\begin{array}{l}\text { Non- } \\
\text { digital }\end{array}$ & Non-digital & Offline & Online \\
\hline 992 & Offline & Online & Online & Brain + n-d & $\begin{array}{l}\text { Non- } \\
\text { digital }\end{array}$ & Non-digital & Offline & Offline \\
\hline 993 & Offline & Online & Online & Brain + n-d & $\begin{array}{l}\text { Non- } \\
\text { digital }\end{array}$ & Blended & Online & Online \\
\hline 994 & Offline & Online & Online & Brain + n-d & $\begin{array}{l}\text { Non- } \\
\text { digital }\end{array}$ & Blended & Online & Offline \\
\hline 995 & Offline & Online & Online & Brain + n-d & $\begin{array}{l}\text { Non- } \\
\text { digital }\end{array}$ & Blended & Offline & Online \\
\hline 996 & Offline & Online & Online & Brain + n-d & $\begin{array}{l}\text { Non- } \\
\text { digital }\end{array}$ & Blended & Offline & Offline \\
\hline 997 & Offline & Online & Online & Brain + n-d & $\begin{array}{l}\text { Blend- } \\
\text { ed }\end{array}$ & Digital & Online & Online \\
\hline 998 & Offline & Online & Online & Brain + n-d & $\begin{array}{l}\text { Blend- } \\
\text { ed }\end{array}$ & Digital & Online & Offline \\
\hline 999 & Offline & Online & Online & Brain + n-d & $\begin{array}{l}\text { Blend- } \\
\text { ed }\end{array}$ & Digital & Offline & Online \\
\hline 1000 & Offline & Online & Online & Brain + n-d & $\begin{array}{l}\text { Blend- } \\
\text { ed }\end{array}$ & Digital & Offline & Offline \\
\hline 1001 & Offline & Online & Online & Brain + n-d & $\begin{array}{l}\text { Blend- } \\
\text { ed }\end{array}$ & Non-digital & Online & Online \\
\hline 1002 & Offline & Online & Online & Brain + n-d & $\begin{array}{l}\text { Blend- } \\
\text { ed }\end{array}$ & Non-digital & Online & Offline \\
\hline
\end{tabular}




\begin{tabular}{|c|c|c|c|c|c|c|c|c|}
\hline 1003 & Offline & Online & Online & Brain + n-d & $\begin{array}{l}\text { Blend- } \\
\text { ed }\end{array}$ & Non-digital & Offline & Online \\
\hline 1004 & Offline & Online & Online & Brain $+n-d$ & $\begin{array}{l}\text { Blend- } \\
\text { ed }\end{array}$ & Non-digital & Offline & Offline \\
\hline 1005 & Offline & Online & Online & Brain $+n-d$ & $\begin{array}{l}\text { Blend- } \\
\text { ed }\end{array}$ & Blended & Online & Online \\
\hline 1006 & Offline & Online & Online & Brain + n-d & $\begin{array}{l}\text { Blend- } \\
\text { ed }\end{array}$ & Blended & Online & Offline \\
\hline 1007 & Offline & Online & Online & Brain $+n-d$ & $\begin{array}{l}\text { Blend- } \\
\text { ed }\end{array}$ & Blended & Offline & Online \\
\hline 1008 & Offline & Online & Online & Brain + n-d & $\begin{array}{l}\text { Blend- } \\
\text { ed }\end{array}$ & Blended & Offline & Offline \\
\hline 1009 & Offline & Online & Offline & Brain + digital & Digital & Digital & Online & Online \\
\hline 1010 & Offline & Online & Offline & Brain + digital & Digital & Digital & Online & Offline \\
\hline 1011 & Offline & Online & Offline & Brain + digital & Digital & Digital & Offline & Online \\
\hline 1012 & Offline & Online & Offline & Brain + digital & Digital & Digital & Offline & Offline \\
\hline 1013 & Offline & Online & Offline & Brain + digital & Digital & Non-digital & Online & Online \\
\hline 1014 & Offline & Online & Offline & Brain + digital & Digital & Non-digital & Online & Offline \\
\hline 1015 & Offline & Online & Offline & Brain + digital & Digital & Non-digital & Offline & Online \\
\hline 1016 & Offline & Online & Offline & Brain + digital & Digital & Non-digital & Offline & Offline \\
\hline 1017 & Offline & Online & Offline & Brain + digital & Digital & Blended & Online & Online \\
\hline 1018 & Offline & Online & Offline & Brain + digital & Digital & Blended & Online & Offline \\
\hline 1019 & Offline & Online & Offline & Brain + digital & Digital & Blended & Offline & Online \\
\hline 1020 & Offline & Online & Offline & Brain + digital & Digital & Blended & Offline & Offline \\
\hline 1021 & Offline & Online & Offline & Brain + digital & $\begin{array}{l}\text { Non- } \\
\text { digital }\end{array}$ & Digital & Online & Online \\
\hline 1022 & Offline & Online & Offline & Brain + digital & $\begin{array}{l}\text { Non- } \\
\text { digital }\end{array}$ & Digital & Online & Offline \\
\hline 1023 & Offline & Online & Offline & Brain + digital & $\begin{array}{l}\text { Non- } \\
\text { digital }\end{array}$ & Digital & Offline & Online \\
\hline 1024 & Offline & Online & Offline & Brain + digital & $\begin{array}{l}\text { Non- } \\
\text { digital }\end{array}$ & Digital & Offline & Offline \\
\hline 1025 & Offline & Online & Offline & Brain + digital & $\begin{array}{l}\text { Non- } \\
\text { digital }\end{array}$ & Non-digital & Online & Online \\
\hline 1026 & Offline & Online & Offline & Brain + digital & $\begin{array}{l}\text { Non- } \\
\text { digital }\end{array}$ & Non-digital & Online & Offline \\
\hline 1027 & Offline & Online & Offline & Brain + digital & $\begin{array}{l}\text { Non- } \\
\text { digital }\end{array}$ & Non-digital & Offline & Online \\
\hline 1028 & Offline & Online & Offline & Brain + digital & $\begin{array}{l}\text { Non- } \\
\text { digital }\end{array}$ & Non-digital & Offline & Offline \\
\hline 1029 & Offline & Online & Offline & Brain + digital & $\begin{array}{l}\text { Non- } \\
\text { digital }\end{array}$ & Blended & Online & Online \\
\hline 1030 & Offline & Online & Offline & Brain + digital & $\begin{array}{l}\text { Non- } \\
\text { digital }\end{array}$ & Blended & Online & Offline \\
\hline 1031 & Offline & Online & Offline & Brain + digital & $\begin{array}{l}\text { Non- } \\
\text { digital }\end{array}$ & Blended & Offline & Online \\
\hline 1032 & Offline & Online & Offline & Brain + digital & $\begin{array}{l}\text { Non- } \\
\text { digital }\end{array}$ & Blended & Offline & Offline \\
\hline 1033 & Offline & Online & Offline & Brain + digital & $\begin{array}{l}\text { Blend- } \\
\text { ed }\end{array}$ & Digital & Online & Online \\
\hline 1034 & Offline & Online & Offline & Brain + digital & $\begin{array}{l}\text { Blend- } \\
\text { ed }\end{array}$ & Digital & Online & Offline \\
\hline 1035 & Offline & Online & Offline & Brain + digital & $\begin{array}{l}\text { Blend- } \\
\text { ed }\end{array}$ & Digital & Offline & Online \\
\hline 1036 & Offline & Online & Offline & Brain + digital & $\begin{array}{l}\text { Blend- } \\
\text { ed }\end{array}$ & Digital & Offline & Offline \\
\hline 1037 & Offline & Online & Offline & Brain + digital & $\begin{array}{l}\text { Blend- } \\
\text { ed }\end{array}$ & Non-digital & Online & Online \\
\hline 1038 & Offline & Online & Offline & Brain + digital & $\begin{array}{l}\text { Blend- } \\
\text { ed }\end{array}$ & Non-digital & Online & Offline \\
\hline 1039 & Offline & Online & Offline & Brain + digital & $\begin{array}{l}\text { Blend- } \\
\text { ed }\end{array}$ & Non-digital & Offline & Online \\
\hline 1040 & Offline & Online & Offline & Brain + digital & $\begin{array}{l}\text { Blend- } \\
\text { ed }\end{array}$ & Non-digital & Offline & Offline \\
\hline
\end{tabular}




\begin{tabular}{|c|c|c|c|c|c|c|c|c|}
\hline 1041 & Offline & Online & Offline & Brain + digital & $\begin{array}{l}\text { Blend- } \\
\text { ed }\end{array}$ & Blended & Online & Online \\
\hline 1042 & Offline & Online & Offline & Brain + digital & $\begin{array}{l}\text { Blend- } \\
\text { ed }\end{array}$ & Blended & Online & Offline \\
\hline 1043 & Offline & Online & Offline & Brain + digital & $\begin{array}{l}\text { Blend- } \\
\text { ed }\end{array}$ & Blended & Offline & Online \\
\hline 1044 & Offline & Online & Offline & Brain + digital & $\begin{array}{l}\text { Blend- } \\
\text { ed }\end{array}$ & Blended & Offline & Offline \\
\hline 1045 & Offline & Online & Offline & Brain & Digital & Digital & Online & Online \\
\hline 1046 & Offline & Online & Offline & Brain & Digital & Digital & Online & Offline \\
\hline 1047 & Offline & Online & Offline & Brain & Digital & Digital & Offline & Online \\
\hline 1048 & Offline & Online & Offline & Brain & Digital & Digital & Offline & Offline \\
\hline 1049 & Offline & Online & Offline & Brain & Digital & Non-digital & Online & Online \\
\hline 1050 & Offline & Online & Offline & Brain & Digital & Non-digital & Online & Offline \\
\hline 1051 & Offline & Online & Offline & Brain & Digital & Non-digital & Offline & Online \\
\hline 1052 & Offline & Online & Offline & Brain & Digital & Non-digital & Offline & Offline \\
\hline 1053 & Offline & Online & Offline & Brain & Digital & Blended & Online & Online \\
\hline 1054 & Offline & Online & Offline & Brain & Digital & Blended & Online & Offline \\
\hline 1055 & Offline & Online & Offline & Brain & Digital & Blended & Offline & Online \\
\hline 1056 & Offline & Online & Offline & Brain & Digital & Blended & Offline & Offline \\
\hline 1057 & Offline & Online & Offline & Brain & $\begin{array}{l}\text { Non- } \\
\text { digital }\end{array}$ & Digital & Online & Online \\
\hline 1058 & Offline & Online & Offline & Brain & $\begin{array}{l}\text { Non- } \\
\text { digital }\end{array}$ & Digital & Online & Offline \\
\hline 1059 & Offline & Online & Offline & Brain & $\begin{array}{l}\text { Non- } \\
\text { digital }\end{array}$ & Digital & Offline & Online \\
\hline 1060 & Offline & Online & Offline & Brain & $\begin{array}{l}\text { Non- } \\
\text { digital }\end{array}$ & Digital & Offline & Offline \\
\hline 1061 & Offline & Online & Offline & Brain & $\begin{array}{l}\text { Non- } \\
\text { digital }\end{array}$ & Non-digital & Online & Online \\
\hline 1062 & Offline & Online & Offline & Brain & $\begin{array}{l}\text { Non- } \\
\text { digital }\end{array}$ & Non-digital & Online & Offline \\
\hline 1063 & Offline & Online & Offline & Brain & $\begin{array}{l}\text { Non- } \\
\text { digital }\end{array}$ & Non-digital & Offline & Online \\
\hline 1064 & Offline & Online & Offline & Brain & $\begin{array}{l}\text { Non- } \\
\text { digital }\end{array}$ & Non-digital & Offline & Offline \\
\hline 1065 & Offline & Online & Offline & Brain & $\begin{array}{l}\text { Non- } \\
\text { digital }\end{array}$ & Blended & Online & Online \\
\hline 1066 & Offline & Online & Offline & Brain & $\begin{array}{l}\text { Non- } \\
\text { digital }\end{array}$ & Blended & Online & Offline \\
\hline 1067 & Offline & Online & Offline & Brain & $\begin{array}{l}\text { Non- } \\
\text { digital }\end{array}$ & Blended & Offline & Online \\
\hline 1068 & Offline & Online & Offline & Brain & $\begin{array}{l}\text { Non- } \\
\text { digital }\end{array}$ & Blended & Offline & Offline \\
\hline 1069 & Offline & Online & Offline & Brain & $\begin{array}{l}\text { Blend- } \\
\text { ed }\end{array}$ & Digital & Online & Online \\
\hline 1070 & Offline & Online & Offline & Brain & $\begin{array}{l}\text { Blend- } \\
\text { ed }\end{array}$ & Digital & Online & Offline \\
\hline 1071 & Offline & Online & Offline & Brain & $\begin{array}{l}\text { Blend- } \\
\text { ed }\end{array}$ & Digital & Offline & Online \\
\hline 1072 & Offline & Online & Offline & Brain & $\begin{array}{l}\text { Blend- } \\
\text { ed }\end{array}$ & Digital & Offline & Offline \\
\hline 1073 & Offline & Online & Offline & Brain & $\begin{array}{l}\text { Blend- } \\
\text { ed }\end{array}$ & Non-digital & Online & Online \\
\hline 1074 & Offline & Online & Offline & Brain & $\begin{array}{l}\text { Blend- } \\
\text { ed }\end{array}$ & Non-digital & Online & Offline \\
\hline 1075 & Offline & Online & Offline & Brain & $\begin{array}{l}\text { Blend- } \\
\text { ed }\end{array}$ & Non-digital & Offline & Online \\
\hline 1076 & Offline & Online & Offline & Brain & $\begin{array}{l}\text { Blend- } \\
\text { ed }\end{array}$ & Non-digital & Offline & Offline \\
\hline 1077 & Offline & Online & Offline & Brain & $\begin{array}{l}\text { Blend- } \\
\text { ed }\end{array}$ & Blended & Online & Online \\
\hline 1078 & Offline & Online & Offline & Brain & $\begin{array}{l}\text { Blend- } \\
\text { ed }\end{array}$ & Blended & Online & Offline \\
\hline
\end{tabular}




\begin{tabular}{|c|c|c|c|c|c|c|c|c|}
\hline 1079 & Offline & Online & Offline & Brain & $\begin{array}{l}\text { Blend- } \\
\text { ed }\end{array}$ & Blended & Offline & Online \\
\hline 1080 & Offline & Online & Offline & Brain & $\begin{array}{l}\text { Blend- } \\
\text { ed }\end{array}$ & Blended & Offline & Offline \\
\hline 1081 & Offline & Online & Offline & Brain $+d+n-d$ & Digital & Digital & Online & Online \\
\hline 1082 & Offline & Online & Offline & Brain $+d+n-d$ & Digital & Digital & Online & Offline \\
\hline 1083 & Offline & Online & Offline & Brain $+d+n-d$ & Digital & Digital & Offline & Online \\
\hline 1084 & Offline & Online & Offline & Brain $+d+n-d$ & Digital & Digital & Offline & Offline \\
\hline 1085 & Offline & Online & Offline & Brain $+d+n-d$ & Digital & Non-digital & Online & Online \\
\hline 1086 & Offline & Online & Offline & Brain $+d+n-d$ & Digital & Non-digital & Online & Offline \\
\hline 1087 & Offline & Online & Offline & Brain $+d+n-d$ & Digital & Non-digital & Offline & Online \\
\hline 1088 & Offline & Online & Offline & Brain $+d+n-d$ & Digital & Non-digital & Offline & Offline \\
\hline 1089 & Offline & Online & Offline & Brain $+d+n-d$ & Digital & Blended & Online & Online \\
\hline 1090 & Offline & Online & Offline & Brain $+d+n-d$ & Digital & Blended & Online & Offline \\
\hline 1091 & Offline & Online & Offline & Brain $+d+n-d$ & Digital & Blended & Offline & Online \\
\hline 1092 & Offline & Online & Offline & Brain $+d+n-d$ & Digital & Blended & Offline & Offline \\
\hline 1093 & Offline & Online & Offline & Brain $+d+n-d$ & $\begin{array}{l}\text { Non- } \\
\text { digital }\end{array}$ & Digital & Online & Online \\
\hline 1094 & Offline & Online & Offline & Brain + d + n-d & $\begin{array}{l}\text { Non- } \\
\text { digital }\end{array}$ & Digital & Online & Offline \\
\hline 1095 & Offline & Online & Offline & Brain $+d+n-d$ & $\begin{array}{l}\text { Non- } \\
\text { digital }\end{array}$ & Digital & Offline & Online \\
\hline 1096 & Offline & Online & Offline & Brain $+d+n-d$ & $\begin{array}{l}\text { Non- } \\
\text { digital }\end{array}$ & Digital & Offline & Offline \\
\hline 1097 & Offline & Online & Offline & Brain + d + n-d & $\begin{array}{l}\text { Non- } \\
\text { digital }\end{array}$ & Non-digital & Online & Online \\
\hline 1098 & Offline & Online & Offline & Brain + d + n-d & $\begin{array}{l}\text { Non- } \\
\text { digital }\end{array}$ & Non-digital & Online & Offline \\
\hline 1099 & Offline & Online & Offline & Brain $+d+n-d$ & $\begin{array}{l}\text { Non- } \\
\text { digital }\end{array}$ & Non-digital & Offline & Online \\
\hline 1100 & Offline & Online & Offline & Brain $+d+n-d$ & $\begin{array}{l}\text { Non- } \\
\text { digital }\end{array}$ & Non-digital & Offline & Offline \\
\hline 1101 & Offline & Online & Offline & Brain + d + n-d & $\begin{array}{l}\text { Non- } \\
\text { digital }\end{array}$ & Blended & Online & Online \\
\hline 1102 & Offline & Online & Offline & Brain $+d+n-d$ & $\begin{array}{l}\text { Non- } \\
\text { digital }\end{array}$ & Blended & Online & Offline \\
\hline 1103 & Offline & Online & Offline & Brain $+d+n-d$ & $\begin{array}{l}\text { Non- } \\
\text { digital }\end{array}$ & Blended & Offline & Online \\
\hline 1104 & Offline & Online & Offline & Brain + d + n-d & $\begin{array}{l}\text { Non- } \\
\text { digital }\end{array}$ & Blended & Offline & Offline \\
\hline 1105 & Offline & Online & Offline & Brain $+d+n-d$ & $\begin{array}{l}\text { Blend- } \\
\text { ed }\end{array}$ & Digital & Online & Online \\
\hline 1106 & Offline & Online & Offline & Brain $+d+n-d$ & $\begin{array}{l}\text { Blend- } \\
\text { ed }\end{array}$ & Digital & Online & Offline \\
\hline 1107 & Offline & Online & Offline & Brain + d + n-d & $\begin{array}{l}\text { Blend- } \\
\text { ed }\end{array}$ & Digital & Offline & Online \\
\hline 1108 & Offline & Online & Offline & Brain + d + n-d & $\begin{array}{l}\text { Blend- } \\
\text { ed }\end{array}$ & Digital & Offline & Offline \\
\hline 1109 & Offline & Online & Offline & Brain + d + n-d & $\begin{array}{l}\text { Blend- } \\
\text { ed }\end{array}$ & Non-digital & Online & Online \\
\hline 1110 & Offline & Online & Offline & Brain $+d+n-d$ & $\begin{array}{l}\text { Blend- } \\
\text { ed }\end{array}$ & Non-digital & Online & Offline \\
\hline 1111 & Offline & Online & Offline & Brain + d + n-d & $\begin{array}{l}\text { Blend- } \\
\text { ed }\end{array}$ & Non-digital & Offline & Online \\
\hline 1112 & Offline & Online & Offline & Brain + d + n-d & $\begin{array}{l}\text { Blend- } \\
\text { ed }\end{array}$ & Non-digital & Offline & Offline \\
\hline 1113 & Offline & Online & Offline & Brain $+d+n-d$ & $\begin{array}{l}\text { Blend- } \\
\text { ed }\end{array}$ & Blended & Online & Online \\
\hline 1114 & Offline & Online & Offline & Brain + d + n-d & $\begin{array}{l}\text { Blend- } \\
\text { ed }\end{array}$ & Blended & Online & Offline \\
\hline 1115 & Offline & Online & Offline & Brain $+d+n-d$ & Blend- & Blended & Offline & Online \\
\hline 1116 & Offline & Online & Offline & Brain $+d+n-d$ & $\begin{array}{l}\text { Blend- } \\
\text { ed }\end{array}$ & Blended & Offline & Offline \\
\hline 1117 & Offline & Online & Offline & Brain $+n-d$ & Digital & Digital & Online & Online \\
\hline
\end{tabular}




\begin{tabular}{|c|c|c|c|c|c|c|c|c|}
\hline 1118 & Offline & Online & Offline & Brain + n-d & Digital & Digital & Online & Offline \\
\hline 1119 & Offline & Online & Offline & Brain + n-d & Digital & Digital & Offline & Online \\
\hline 1120 & Offline & Online & Offline & Brain + n-d & Digital & Digital & Offline & Offline \\
\hline 1121 & Offline & Online & Offline & Brain + n-d & Digital & Non-digital & Online & Online \\
\hline 1122 & Offline & Online & Offline & Brain + n-d & Digital & Non-digital & Online & Offline \\
\hline 1123 & Offline & Online & Offline & Brain + n-d & Digital & Non-digital & Offline & Online \\
\hline 1124 & Offline & Online & Offline & Brain + n-d & Digital & Non-digital & Offline & Offline \\
\hline 1125 & Offline & Online & Offline & Brain + n-d & Digital & Blended & Online & Online \\
\hline 1126 & Offline & Online & Offline & Brain + n-d & Digital & Blended & Online & Offline \\
\hline 1127 & Offline & Online & Offline & Brain + n-d & Digital & Blended & Offline & Online \\
\hline 1128 & Offline & Online & Offline & Brain + n-d & Digital & Blended & Offline & Offline \\
\hline 1129 & Offline & Online & Offline & Brain + n-d & $\begin{array}{l}\text { Non- } \\
\text { digital }\end{array}$ & Digital & Online & Online \\
\hline 1130 & Offline & Online & Offline & Brain + n-d & $\begin{array}{l}\text { Non- } \\
\text { digital }\end{array}$ & Digital & Online & Offline \\
\hline 1131 & Offline & Online & Offline & Brain $+n-d$ & $\begin{array}{l}\text { Non- } \\
\text { digital }\end{array}$ & Digital & Offline & Online \\
\hline 1132 & Offline & Online & Offline & Brain $+n-d$ & $\begin{array}{l}\text { Non- } \\
\text { digital }\end{array}$ & Digital & Offline & Offline \\
\hline 1133 & Offline & Online & Offline & Brain + n-d & $\begin{array}{l}\text { Non- } \\
\text { digital }\end{array}$ & Non-digital & Online & Online \\
\hline 1134 & Offline & Online & Offline & Brain + n-d & $\begin{array}{l}\text { Non- } \\
\text { digital }\end{array}$ & Non-digital & Online & Offline \\
\hline 1135 & Offline & Online & Offline & Brain + n-d & $\begin{array}{l}\text { Non- } \\
\text { digital }\end{array}$ & Non-digital & Offline & Online \\
\hline 1136 & Offline & Online & Offline & Brain + n-d & $\begin{array}{l}\text { Non- } \\
\text { digital }\end{array}$ & Non-digital & Offline & Offline \\
\hline 1137 & Offline & Online & Offline & Brain + n-d & $\begin{array}{l}\text { Non- } \\
\text { digital }\end{array}$ & Blended & Online & Online \\
\hline 1138 & Offline & Online & Offline & Brain + n-d & $\begin{array}{l}\text { Non- } \\
\text { digital }\end{array}$ & Blended & Online & Offline \\
\hline 1139 & Offline & Online & Offline & Brain + n-d & $\begin{array}{l}\text { Non- } \\
\text { digital }\end{array}$ & Blended & Offline & Online \\
\hline 1140 & Offline & Online & Offline & Brain + n-d & $\begin{array}{l}\text { Non- } \\
\text { digital }\end{array}$ & Blended & Offline & Offline \\
\hline 1141 & Offline & Online & Offline & Brain + n-d & $\begin{array}{l}\text { Blend- } \\
\text { ed }\end{array}$ & Digital & Online & Online \\
\hline 1142 & Offline & Online & Offline & Brain + n-d & $\begin{array}{l}\text { Blend- } \\
\text { ed }\end{array}$ & Digital & Online & Offline \\
\hline 1143 & Offline & Online & Offline & Brain + n-d & $\begin{array}{l}\text { Blend- } \\
\text { ed }\end{array}$ & Digital & Offline & Online \\
\hline 1144 & Offline & Online & Offline & Brain + n-d & $\begin{array}{l}\text { Blend- } \\
\text { ed }\end{array}$ & Digital & Offline & Offline \\
\hline 1145 & Offline & Online & Offline & Brain + n-d & $\begin{array}{l}\text { Blend- } \\
\text { ed }\end{array}$ & Non-digital & Online & Online \\
\hline 1146 & Offline & Online & Offline & Brain + n-d & $\begin{array}{l}\text { Blend- } \\
\text { ed }\end{array}$ & Non-digital & Online & Offline \\
\hline 1147 & Offline & Online & Offline & Brain + n-d & $\begin{array}{l}\text { Blend- } \\
\text { ed }\end{array}$ & Non-digital & Offline & Online \\
\hline 1148 & Offline & Online & Offline & Brain + n-d & $\begin{array}{l}\text { Blend- } \\
\text { ed }\end{array}$ & Non-digital & Offline & Offline \\
\hline 1149 & Offline & Online & Offline & Brain + n-d & $\begin{array}{l}\text { Blend- } \\
\text { ed }\end{array}$ & Blended & Online & Online \\
\hline 1150 & Offline & Online & Offline & Brain + n-d & $\begin{array}{l}\text { Blend- } \\
\text { ed }\end{array}$ & Blended & Online & Offline \\
\hline 1151 & Offline & Online & Offline & Brain + n-d & $\begin{array}{l}\text { Blend- } \\
\text { ed }\end{array}$ & Blended & Offline & Online \\
\hline 1152 & Offline & Online & Offline & Brain + n-d & $\begin{array}{l}\text { Blend- } \\
\text { ed }\end{array}$ & Blended & Offline & Offline \\
\hline 1153 & Offline & Online & Blended & Brain + digital & Digital & Digital & Online & Online \\
\hline 1154 & Offline & Online & Blended & Brain + digital & Digital & Digital & Online & Offline \\
\hline 1155 & Offline & Online & Blended & Brain + digital & Digital & Digital & Offline & Online \\
\hline 1156 & Offline & Online & Blended & Brain + digital & Digital & Digital & Offline & Offline \\
\hline 1157 & Offline & Online & Blended & Brain + digital & Digital & Non-digital & Online & Online \\
\hline 1158 & Offline & Online & Blended & Brain + digital & Digital & Non-digital & Online & Offline \\
\hline
\end{tabular}




\begin{tabular}{|c|c|c|c|c|c|c|c|c|}
\hline 1159 & Offline & Online & Blended & Brain + digital & Digital & Non-digital & Offline & Online \\
\hline 1160 & Offline & Online & Blended & Brain + digital & Digital & Non-digital & Offline & Offline \\
\hline 1161 & Offline & Online & Blended & Brain + digital & Digital & Blended & Online & Online \\
\hline 1162 & Offline & Online & Blended & Brain + digital & Digital & Blended & Online & Offline \\
\hline 1163 & Offline & Online & Blended & Brain + digital & Digital & Blended & Offline & Online \\
\hline 1164 & Offline & Online & Blended & Brain + digital & Digital & Blended & Offline & Offline \\
\hline 1165 & Offline & Online & Blended & Brain + digital & $\begin{array}{l}\text { Non- } \\
\text { digital }\end{array}$ & Digital & Online & Online \\
\hline 1166 & Offline & Online & Blended & Brain + digital & $\begin{array}{l}\text { Non- } \\
\text { digital }\end{array}$ & Digital & Online & Offline \\
\hline 1167 & Offline & Online & Blended & Brain + digital & $\begin{array}{l}\text { Non- } \\
\text { digital }\end{array}$ & Digital & Offline & Online \\
\hline 1168 & Offline & Online & Blended & Brain + digital & $\begin{array}{l}\text { Non- } \\
\text { digital }\end{array}$ & Digital & Offline & Offline \\
\hline 1169 & Offline & Online & Blended & Brain + digital & $\begin{array}{l}\text { Non- } \\
\text { digital }\end{array}$ & Non-digital & Online & Online \\
\hline 1170 & Offline & Online & Blended & Brain + digital & $\begin{array}{l}\text { Non- } \\
\text { digital }\end{array}$ & Non-digital & Online & Offline \\
\hline 1171 & Offline & Online & Blended & Brain + digital & $\begin{array}{l}\text { Non- } \\
\text { digital }\end{array}$ & Non-digital & Offline & Online \\
\hline 1172 & Offline & Online & Blended & Brain + digital & $\begin{array}{l}\text { Non- } \\
\text { digital }\end{array}$ & Non-digital & Offline & Offline \\
\hline 1173 & Offline & Online & Blended & Brain + digital & $\begin{array}{l}\text { Non- } \\
\text { digital }\end{array}$ & Blended & Online & Online \\
\hline 1174 & Offline & Online & Blended & Brain + digital & $\begin{array}{l}\text { Non- } \\
\text { digital }\end{array}$ & Blended & Online & Offline \\
\hline 1175 & Offline & Online & Blended & Brain + digital & $\begin{array}{l}\text { Non- } \\
\text { digital }\end{array}$ & Blended & Offline & Online \\
\hline 1176 & Offline & Online & Blended & Brain + digital & $\begin{array}{l}\text { Non- } \\
\text { digital }\end{array}$ & Blended & Offline & Offline \\
\hline 1177 & Offline & Online & Blended & Brain + digital & $\begin{array}{l}\text { Blend- } \\
\text { ed }\end{array}$ & Digital & Online & Online \\
\hline 1178 & Offline & Online & Blended & Brain + digital & $\begin{array}{l}\text { Blend- } \\
\text { ed }\end{array}$ & Digital & Online & Offline \\
\hline 1179 & Offline & Online & Blended & Brain + digital & $\begin{array}{l}\text { Blend- } \\
\text { ed }\end{array}$ & Digital & Offline & Online \\
\hline 1180 & Offline & Online & Blended & Brain + digital & $\begin{array}{l}\text { Blend- } \\
\text { ed }\end{array}$ & Digital & Offline & Offline \\
\hline 1181 & Offline & Online & Blended & Brain + digital & $\begin{array}{l}\text { Blend- } \\
\text { ed }\end{array}$ & Non-digital & Online & Online \\
\hline 1182 & Offline & Online & Blended & Brain + digital & $\begin{array}{l}\text { Blend- } \\
\text { ed }\end{array}$ & Non-digital & Online & Offline \\
\hline 1183 & Offline & Online & Blended & Brain + digital & $\begin{array}{l}\text { Blend- } \\
\text { ed }\end{array}$ & Non-digital & Offline & Online \\
\hline 1184 & Offline & Online & Blended & Brain + digital & $\begin{array}{l}\text { Blend- } \\
\text { ed }\end{array}$ & Non-digital & Offline & Offline \\
\hline 1185 & Offline & Online & Blended & Brain + digital & $\begin{array}{l}\text { Blend- } \\
\text { ed }\end{array}$ & Blended & Online & Online \\
\hline 1186 & Offline & Online & Blended & Brain + digital & $\begin{array}{l}\text { Blend- } \\
\text { ed }\end{array}$ & Blended & Online & Offline \\
\hline 1187 & Offline & Online & Blended & Brain + digital & $\begin{array}{l}\text { Blend- } \\
\text { ed }\end{array}$ & Blended & Offline & Online \\
\hline 1188 & Offline & Online & Blended & Brain + digital & $\begin{array}{l}\text { Blend- } \\
\text { ed }\end{array}$ & Blended & Offline & Offline \\
\hline 1189 & Offline & Online & Blended & Brain & Digital & Digital & Online & Online \\
\hline 1190 & Offline & Online & Blended & Brain & Digital & Digital & Online & Offline \\
\hline 1191 & Offline & Online & Blended & Brain & Digital & Digital & Offline & Online \\
\hline 1192 & Offline & Online & Blended & Brain & Digital & Digital & Offline & Offline \\
\hline 1193 & Offline & Online & Blended & Brain & Digital & Non-digital & Online & Online \\
\hline 1194 & Offline & Online & Blended & Brain & Digital & Non-digital & Online & Offline \\
\hline 1195 & Offline & Online & Blended & Brain & Digital & Non-digital & Offline & Online \\
\hline 1196 & Offline & Online & Blended & Brain & Digital & Non-digital & Offline & Offline \\
\hline 1197 & Offline & Online & Blended & Brain & Digital & Blended & Online & Online \\
\hline 1198 & Offline & Online & Blended & Brain & Digital & Blended & Online & Offline \\
\hline 1199 & Offline & Online & Blended & Brain & Digital & Blended & Offline & Online \\
\hline
\end{tabular}




\begin{tabular}{|c|c|c|c|c|c|c|c|c|}
\hline 1200 & Offline & Online & Blended & Brain & Digital & Blended & Offline & Offline \\
\hline 1201 & Offline & Online & Blended & Brain & $\begin{array}{l}\text { Non- } \\
\text { digital }\end{array}$ & Digital & Online & Online \\
\hline 1202 & Offline & Online & Blended & Brain & $\begin{array}{l}\text { Non- } \\
\text { digital }\end{array}$ & Digital & Online & Offline \\
\hline 1203 & Offline & Online & Blended & Brain & $\begin{array}{l}\text { Non- } \\
\text { digital }\end{array}$ & Digital & Offline & Online \\
\hline 1204 & Offline & Online & Blended & Brain & $\begin{array}{l}\text { Non- } \\
\text { digital }\end{array}$ & Digital & Offline & Offline \\
\hline 1205 & Offline & Online & Blended & Brain & $\begin{array}{l}\text { Non- } \\
\text { digital }\end{array}$ & Non-digital & Online & Online \\
\hline 1206 & Offline & Online & Blended & Brain & $\begin{array}{l}\text { Non- } \\
\text { digital }\end{array}$ & Non-digital & Online & Offline \\
\hline 1207 & Offline & Online & Blended & Brain & $\begin{array}{l}\text { Non- } \\
\text { digital }\end{array}$ & Non-digital & Offline & Online \\
\hline 1208 & Offline & Online & Blended & Brain & $\begin{array}{l}\text { Non- } \\
\text { digital }\end{array}$ & Non-digital & Offline & Offline \\
\hline 1209 & Offline & Online & Blended & Brain & $\begin{array}{l}\text { Non- } \\
\text { digital }\end{array}$ & Blended & Online & Online \\
\hline 1210 & Offline & Online & Blended & Brain & $\begin{array}{l}\text { Non- } \\
\text { digital }\end{array}$ & Blended & Online & Offline \\
\hline 1211 & Offline & Online & Blended & Brain & $\begin{array}{l}\text { Non- } \\
\text { digital }\end{array}$ & Blended & Offline & Online \\
\hline 1212 & Offline & Online & Blended & Brain & $\begin{array}{l}\text { Non- } \\
\text { digital }\end{array}$ & Blended & Offline & Offline \\
\hline 1213 & Offline & Online & Blended & Brain & $\begin{array}{l}\text { Blend- } \\
\text { ed }\end{array}$ & Digital & Online & Online \\
\hline 1214 & Offline & Online & Blended & Brain & $\begin{array}{l}\text { Blend- } \\
\text { ed }\end{array}$ & Digital & Online & Offline \\
\hline 1215 & Offline & Online & Blended & Brain & $\begin{array}{l}\text { Blend- } \\
\text { ed }\end{array}$ & Digital & Offline & Online \\
\hline 1216 & Offline & Online & Blended & Brain & $\begin{array}{l}\text { Blend- } \\
\text { ed }\end{array}$ & Digital & Offline & Offline \\
\hline 1217 & Offline & Online & Blended & Brain & $\begin{array}{l}\text { Blend- } \\
\text { ed }\end{array}$ & Non-digital & Online & Online \\
\hline 1218 & Offline & Online & Blended & Brain & $\begin{array}{l}\text { Blend- } \\
\text { ed }\end{array}$ & Non-digital & Online & Offline \\
\hline 1219 & Offline & Online & Blended & Brain & $\begin{array}{l}\text { Blend- } \\
\text { ed }\end{array}$ & Non-digital & Offline & Online \\
\hline 1220 & Offline & Online & Blended & Brain & $\begin{array}{l}\text { Blend- } \\
\text { ed }\end{array}$ & Non-digital & Offline & Offline \\
\hline 1221 & Offline & Online & Blended & Brain & $\begin{array}{l}\text { Blend- } \\
\text { ed }\end{array}$ & Blended & Online & Online \\
\hline 1222 & Offline & Online & Blended & Brain & $\begin{array}{l}\text { Blend- } \\
\text { ed }\end{array}$ & Blended & Online & Offline \\
\hline 1223 & Offline & Online & Blended & Brain & $\begin{array}{l}\text { Blend- } \\
\text { ed }\end{array}$ & Blended & Offline & Online \\
\hline 1224 & Offline & Online & Blended & Brain & $\begin{array}{l}\text { Blend- } \\
\text { ed }\end{array}$ & Blended & Offline & Offline \\
\hline 1225 & Offline & Online & Blended & Brain $+d+n-d$ & Digital & Digital & Online & Online \\
\hline 1226 & Offline & Online & Blended & Brain $+d+n-d$ & Digital & Digital & Online & Offline \\
\hline 1227 & Offline & Online & Blended & Brain $+d+n-d$ & Digital & Digital & Offline & Online \\
\hline 1228 & Offline & Online & Blended & Brain $+d+n-d$ & Digital & Digital & Offline & Offline \\
\hline 1229 & Offline & Online & Blended & Brain $+d+n-d$ & Digital & Non-digital & Online & Online \\
\hline 1230 & Offline & Online & Blended & Brain $+d+n-d$ & Digital & Non-digital & Online & Offline \\
\hline 1231 & Offline & Online & Blended & Brain $+d+n-d$ & Digital & Non-digital & Offline & Online \\
\hline 1232 & Offline & Online & Blended & Brain $+d+n-d$ & Digital & Non-digital & Offline & Offline \\
\hline 1233 & Offline & Online & Blended & Brain $+d+n-d$ & Digital & Blended & Online & Online \\
\hline 1234 & Offline & Online & Blended & Brain $+d+n-d$ & Digital & Blended & Online & Offline \\
\hline 1235 & Offline & Online & Blended & Brain $+d+n-d$ & Digital & Blended & Offline & Online \\
\hline 1236 & Offline & Online & Blended & Brain + d + n-d & Digital & Blended & Offline & Offline \\
\hline 1237 & Offline & Online & Blended & Brain $+d+n-d$ & $\begin{array}{l}\text { Non- } \\
\text { digital }\end{array}$ & Digital & Online & Online \\
\hline 1238 & Offline & Online & Blended & Brain $+d+n-d$ & $\begin{array}{l}\text { Non- } \\
\text { digital }\end{array}$ & Digital & Online & Offline \\
\hline
\end{tabular}




\begin{tabular}{|c|c|c|c|c|c|c|c|c|}
\hline 1239 & Offline & Online & Blended & Brain $+d+n-d$ & $\begin{array}{l}\text { Non- } \\
\text { digital }\end{array}$ & Digital & Offline & Online \\
\hline 1240 & Offline & Online & Blended & Brain $+d+n-d$ & $\begin{array}{l}\text { Non- } \\
\text { digital }\end{array}$ & Digital & Offline & Offline \\
\hline 1241 & Offline & Online & Blended & Brain $+d+n-d$ & $\begin{array}{l}\text { Non- } \\
\text { digital }\end{array}$ & Non-digital & Online & Online \\
\hline 1242 & Offline & Online & Blended & Brain $+d+n-d$ & $\begin{array}{l}\text { Non- } \\
\text { digital }\end{array}$ & Non-digital & Online & Offline \\
\hline 1243 & Offline & Online & Blended & Brain $+d+n-d$ & $\begin{array}{l}\text { Non- } \\
\text { digital }\end{array}$ & Non-digital & Offline & Online \\
\hline 1244 & Offline & Online & Blended & Brain $+d+n-d$ & $\begin{array}{l}\text { Non- } \\
\text { digital }\end{array}$ & Non-digital & Offline & Offline \\
\hline 1245 & Offline & Online & Blended & Brain $+d+n-d$ & $\begin{array}{l}\text { Non- } \\
\text { digital }\end{array}$ & Blended & Online & Online \\
\hline 1246 & Offline & Online & Blended & Brain $+d+n-d$ & $\begin{array}{l}\text { Non- } \\
\text { digital }\end{array}$ & Blended & Online & Offline \\
\hline 1247 & Offline & Online & Blended & Brain $+d+n-d$ & $\begin{array}{l}\text { Non- } \\
\text { digital }\end{array}$ & Blended & Offline & Online \\
\hline 1248 & Offline & Online & Blended & Brain $+d+n-d$ & $\begin{array}{l}\text { Non- } \\
\text { digital }\end{array}$ & Blended & Offline & Offline \\
\hline 1249 & Offline & Online & Blended & Brain $+d+n-d$ & $\begin{array}{l}\text { Blend- } \\
\text { ed }\end{array}$ & Digital & Online & Online \\
\hline 1250 & Offline & Online & Blended & Brain $+d+n-d$ & $\begin{array}{l}\text { Blend- } \\
\text { ed }\end{array}$ & Digital & Online & Offline \\
\hline 1251 & Offline & Online & Blended & Brain $+d+n-d$ & $\begin{array}{l}\text { Blend- } \\
\text { ed }\end{array}$ & Digital & Offline & Online \\
\hline 1252 & Offline & Online & Blended & Brain $+d+n-d$ & $\begin{array}{l}\text { Blend- } \\
\text { ed }\end{array}$ & Digital & Offline & Offline \\
\hline 1253 & Offline & Online & Blended & Brain $+d+n-d$ & $\begin{array}{l}\text { Blend- } \\
\text { ed }\end{array}$ & Non-digital & Online & Online \\
\hline 1254 & Offline & Online & Blended & Brain $+d+n-d$ & $\begin{array}{l}\text { Blend- } \\
\text { ed }\end{array}$ & Non-digital & Online & Offline \\
\hline 1255 & Offline & Online & Blended & Brain $+d+n-d$ & $\begin{array}{l}\text { Blend- } \\
\text { ed }\end{array}$ & Non-digital & Offline & Online \\
\hline 1256 & Offline & Online & Blended & Brain $+d+n-d$ & $\begin{array}{l}\text { Blend- } \\
\text { ed }\end{array}$ & Non-digital & Offline & Offline \\
\hline 1257 & Offline & Online & Blended & Brain $+d+n-d$ & $\begin{array}{l}\text { Blend- } \\
\text { ed }\end{array}$ & Blended & Online & Online \\
\hline 1258 & Offline & Online & Blended & Brain $+d+n-d$ & $\begin{array}{l}\text { Blend- } \\
\text { ed }\end{array}$ & Blended & Online & Offline \\
\hline 1259 & Offline & Online & Blended & Brain $+d+n-d$ & $\begin{array}{l}\text { Blend- } \\
\text { ed }\end{array}$ & Blended & Offline & Online \\
\hline 1260 & Offline & Online & Blended & Brain $+d+n-d$ & $\begin{array}{l}\text { Blend- } \\
\text { ed }\end{array}$ & Blended & Offline & Offline \\
\hline 1261 & Offline & Online & Blended & Brain $+n-d$ & Digital & Digital & Online & Online \\
\hline 1262 & Offline & Online & Blended & Brain $+n-d$ & Digital & Digital & Online & Offline \\
\hline 1263 & Offline & Online & Blended & Brain + n-d & Digital & Digital & Offline & Online \\
\hline 1264 & Offline & Online & Blended & Brain + n-d & Digital & Digital & Offline & Offline \\
\hline 1265 & Offline & Online & Blended & Brain + n-d & Digital & Non-digital & Online & Online \\
\hline 1266 & Offline & Online & Blended & Brain + n-d & Digital & Non-digital & Online & Offline \\
\hline 1267 & Offline & Online & Blended & Brain + n-d & Digital & Non-digital & Offline & Online \\
\hline 1268 & Offline & Online & Blended & Brain + n-d & Digital & Non-digital & Offline & Offline \\
\hline 1269 & Offline & Online & Blended & Brain + n-d & Digital & Blended & Online & Online \\
\hline 1270 & Offline & Online & Blended & Brain + n-d & Digital & Blended & Online & Offline \\
\hline 1271 & Offline & Online & Blended & Brain + n-d & Digital & Blended & Offline & Online \\
\hline 1272 & Offline & Online & Blended & Brain + n-d & Digital & Blended & Offline & Offline \\
\hline 1273 & Offline & Online & Blended & Brain $+n-d$ & $\begin{array}{l}\text { Non- } \\
\text { digital }\end{array}$ & Digital & Online & Online \\
\hline 1274 & Offline & Online & Blended & Brain + n-d & $\begin{array}{l}\text { Non- } \\
\text { digital }\end{array}$ & Digital & Online & Offline \\
\hline 1275 & Offline & Online & Blended & Brain + n-d & $\begin{array}{l}\text { Non- } \\
\text { digital }\end{array}$ & Digital & Offline & Online \\
\hline 1276 & Offline & Online & Blended & Brain + n-d & $\begin{array}{l}\text { Non- } \\
\text { digital }\end{array}$ & Digital & Offline & Offline \\
\hline
\end{tabular}




\begin{tabular}{|c|c|c|c|c|c|c|c|c|}
\hline 1277 & Offline & Online & Blended & Brain + n-d & $\begin{array}{l}\text { Non- } \\
\text { digital }\end{array}$ & Non-digital & Online & Online \\
\hline 1278 & Offline & Online & Blended & Brain + n-d & $\begin{array}{l}\text { Non- } \\
\text { digital }\end{array}$ & Non-digital & Online & Offline \\
\hline 1279 & Offline & Online & Blended & Brain + n-d & $\begin{array}{l}\text { Non- } \\
\text { digital }\end{array}$ & Non-digital & Offline & Online \\
\hline 1280 & Offline & Online & Blended & Brain + n-d & $\begin{array}{l}\text { Non- } \\
\text { digital }\end{array}$ & Non-digital & Offline & Offline \\
\hline 1281 & Offline & Online & Blended & Brain + n-d & $\begin{array}{l}\text { Non- } \\
\text { digital }\end{array}$ & Blended & Online & Online \\
\hline 1282 & Offline & Online & Blended & Brain + n-d & $\begin{array}{l}\text { Non- } \\
\text { digital }\end{array}$ & Blended & Online & Offline \\
\hline 1283 & Offline & Online & Blended & Brain + n-d & $\begin{array}{l}\text { Non- } \\
\text { digital }\end{array}$ & Blended & Offline & Online \\
\hline 1284 & Offline & Online & Blended & Brain + n-d & $\begin{array}{l}\text { Non- } \\
\text { digital }\end{array}$ & Blended & Offline & Offline \\
\hline 1285 & Offline & Online & Blended & Brain + n-d & $\begin{array}{l}\text { Blend- } \\
\text { ed }\end{array}$ & Digital & Online & Online \\
\hline 1286 & Offline & Online & Blended & Brain + n-d & $\begin{array}{l}\text { Blend- } \\
\text { ed }\end{array}$ & Digital & Online & Offline \\
\hline 1287 & Offline & Online & Blended & Brain + n-d & $\begin{array}{l}\text { Blend- } \\
\text { ed }\end{array}$ & Digital & Offline & Online \\
\hline 1288 & Offline & Online & Blended & Brain + n-d & $\begin{array}{l}\text { Blend- } \\
\text { ed }\end{array}$ & Digital & Offline & Offline \\
\hline 1289 & Offline & Online & Blended & Brain + n-d & $\begin{array}{l}\text { Blend- } \\
\text { ed }\end{array}$ & Non-digital & Online & Online \\
\hline 1290 & Offline & Online & Blended & Brain + n-d & $\begin{array}{l}\text { Blend- } \\
\text { ed }\end{array}$ & Non-digital & Online & Offline \\
\hline 1291 & Offline & Online & Blended & Brain + n-d & $\begin{array}{l}\text { Blend- } \\
\text { ed }\end{array}$ & Non-digital & Offline & Online \\
\hline 1292 & Offline & Online & Blended & Brain + n-d & $\begin{array}{l}\text { Blend- } \\
\text { ed }\end{array}$ & Non-digital & Offline & Offline \\
\hline \multirow[t]{4}{*}{1293} & Offline & Online & Blended & Brain + n-d & $\begin{array}{l}\text { Blend- } \\
\text { ed }\end{array}$ & Blended & Online & Online \\
\hline & Offline & Online & Blended & Brain + n-d & $\begin{array}{l}\text { Blend- } \\
\text { ed }\end{array}$ & Blended & Online & Offline \\
\hline & Offline & Online & Blended & Brain + n-d & $\begin{array}{l}\text { Blend- } \\
\text { ed }\end{array}$ & Blended & Offline & Online \\
\hline & Offline & Online & Blended & Brain + n-d & $\begin{array}{l}\text { Blend- } \\
\text { ed }\end{array}$ & Blended & Offline & Offline \\
\hline \multicolumn{9}{|l|}{1293} \\
\hline \multicolumn{9}{|l|}{1294} \\
\hline \multicolumn{9}{|l|}{1295} \\
\hline \multicolumn{9}{|l|}{1296} \\
\hline 1297 & Offline & Offline & Online & Brain + digital & Digital & Digital & Online & Online \\
\hline 1298 & Offline & Offline & Online & Brain + digital & Digital & Digital & Online & Offline \\
\hline 1299 & Offline & Offline & Online & Brain + digital & Digital & Digital & Offline & Online \\
\hline 1300 & Offline & Offline & Online & Brain + digital & Digital & Digital & Offline & Offline \\
\hline 1301 & Offline & Offline & Online & Brain + digital & Digital & Non-digital & Online & Online \\
\hline 1302 & Offline & Offline & Online & Brain + digital & Digital & Non-digital & Online & Offline \\
\hline 1303 & Offline & Offline & Online & Brain + digital & Digital & Non-digital & Offline & Online \\
\hline 1304 & Offline & Offline & Online & Brain + digital & Digital & Non-digital & Offline & Offline \\
\hline 1305 & Offline & Offline & Online & Brain + digital & Digital & Blended & Online & Online \\
\hline 1306 & Offline & Offline & Online & Brain + digital & Digital & Blended & Online & Offline \\
\hline 1307 & Offline & Offline & Online & Brain + digital & Digital & Blended & Offline & Online \\
\hline 1308 & Offline & Offline & Online & Brain + digital & Digital & Blended & Offline & Offline \\
\hline 1309 & Offline & Offline & Online & Brain + digital & $\begin{array}{l}\text { Non- } \\
\text { digital }\end{array}$ & Digital & Online & Online \\
\hline 1310 & Offline & Offline & Online & Brain + digital & $\begin{array}{l}\text { Non- } \\
\text { digital }\end{array}$ & Digital & Online & Offline \\
\hline 1311 & Offline & Offline & Online & Brain + digital & $\begin{array}{l}\text { Non- } \\
\text { digital }\end{array}$ & Digital & Offline & Online \\
\hline 1312 & Offline & Offline & Online & Brain + digital & $\begin{array}{l}\text { Non- } \\
\text { digital }\end{array}$ & Digital & Offline & Offline \\
\hline
\end{tabular}




\begin{tabular}{|c|c|c|c|c|c|c|c|c|}
\hline 1313 & Offline & Offline & Online & Brain + digital & $\begin{array}{l}\text { Non- } \\
\text { digital }\end{array}$ & Non-digital & Online & Online \\
\hline 1314 & Offline & Offline & Online & Brain + digital & $\begin{array}{l}\text { Non- } \\
\text { digital }\end{array}$ & Non-digital & Online & Offline \\
\hline 1315 & Offline & Offline & Online & Brain + digital & $\begin{array}{l}\text { Non- } \\
\text { digital }\end{array}$ & Non-digital & Offline & Online \\
\hline 1316 & Offline & Offline & Online & Brain + digital & $\begin{array}{l}\text { Non- } \\
\text { digital }\end{array}$ & Non-digital & Offline & Offline \\
\hline 1317 & Offline & Offline & Online & Brain + digital & $\begin{array}{l}\text { Non- } \\
\text { digital }\end{array}$ & Blended & Online & Online \\
\hline 1318 & Offline & Offline & Online & Brain + digital & $\begin{array}{l}\text { Non- } \\
\text { digital }\end{array}$ & Blended & Online & Offline \\
\hline 1319 & Offline & Offline & Online & Brain + digital & $\begin{array}{l}\text { Non- } \\
\text { digital }\end{array}$ & Blended & Offline & Online \\
\hline 1320 & Offline & Offline & Online & Brain + digital & $\begin{array}{l}\text { Non- } \\
\text { digital }\end{array}$ & Blended & Offline & Offline \\
\hline 1321 & Offline & Offline & Online & Brain + digital & $\begin{array}{l}\text { Blend- } \\
\text { ed }\end{array}$ & Digital & Online & Online \\
\hline 1322 & Offline & Offline & Online & Brain + digital & $\begin{array}{l}\text { Blend- } \\
\text { ed }\end{array}$ & Digital & Online & Offline \\
\hline 1323 & Offline & Offline & Online & Brain + digital & $\begin{array}{l}\text { Blend- } \\
\text { ed }\end{array}$ & Digital & Offline & Online \\
\hline 1324 & Offline & Offline & Online & Brain + digital & $\begin{array}{l}\text { Blend- } \\
\text { ed }\end{array}$ & Digital & Offline & Offline \\
\hline 1325 & Offline & Offline & Online & Brain + digital & $\begin{array}{l}\text { Blend- } \\
\text { ed }\end{array}$ & Non-digital & Online & Online \\
\hline 1326 & Offline & Offline & Online & Brain + digital & $\begin{array}{l}\text { Blend- } \\
\text { ed }\end{array}$ & Non-digital & Online & Offline \\
\hline 1327 & Offline & Offline & Online & Brain + digital & $\begin{array}{l}\text { Blend- } \\
\text { ed }\end{array}$ & Non-digital & Offline & Online \\
\hline 1328 & Offline & Offline & Online & Brain + digital & $\begin{array}{l}\text { Blend- } \\
\text { ed }\end{array}$ & Non-digital & Offline & Offline \\
\hline 1329 & Offline & Offline & Online & Brain + digital & $\begin{array}{l}\text { Blend- } \\
\text { ed }\end{array}$ & Blended & Online & Online \\
\hline 1330 & Offline & Offline & Online & Brain + digital & $\begin{array}{l}\text { Blend- } \\
\text { ed }\end{array}$ & Blended & Online & Offline \\
\hline 1331 & Offline & Offline & Online & Brain + digital & $\begin{array}{l}\text { Blend- } \\
\text { ed }\end{array}$ & Blended & Offline & Online \\
\hline 1332 & Offline & Offline & Online & Brain + digital & $\begin{array}{l}\text { Blend- } \\
\text { ed }\end{array}$ & Blended & Offline & Offline \\
\hline 1333 & Offline & Offline & Online & Brain & Digital & Digital & Online & Online \\
\hline 1334 & Offline & Offline & Online & Brain & Digital & Digital & Online & Offline \\
\hline 1335 & Offline & Offline & Online & Brain & Digital & Digital & Offline & Online \\
\hline 1336 & Offline & Offline & Online & Brain & Digital & Digital & Offline & Offline \\
\hline 1337 & Offline & Offline & Online & Brain & Digital & Non-digital & Online & Online \\
\hline 1338 & Offline & Offline & Online & Brain & Digital & Non-digital & Online & Offline \\
\hline 1339 & Offline & Offline & Online & Brain & Digital & Non-digital & Offline & Online \\
\hline 1340 & Offline & Offline & Online & Brain & Digital & Non-digital & Offline & Offline \\
\hline 1341 & Offline & Offline & Online & Brain & Digital & Blended & Online & Online \\
\hline 1342 & Offline & Offline & Online & Brain & Digital & Blended & Online & Offline \\
\hline 1343 & Offline & Offline & Online & Brain & Digital & Blended & Offline & Online \\
\hline 1344 & Offline & Offline & Online & Brain & Digital & Blended & Offline & Offline \\
\hline 1345 & Offline & Offline & Online & Brain & $\begin{array}{l}\text { Non- } \\
\text { digital }\end{array}$ & Digital & Online & Online \\
\hline 1346 & Offline & Offline & Online & Brain & $\begin{array}{l}\text { Non- } \\
\text { digital }\end{array}$ & Digital & Online & Offline \\
\hline 1347 & Offline & Offline & Online & Brain & $\begin{array}{l}\text { Non- } \\
\text { digital }\end{array}$ & Digital & Offline & Online \\
\hline 1348 & Offline & Offline & Online & Brain & $\begin{array}{l}\text { Non- } \\
\text { digital }\end{array}$ & Digital & Offline & Offline \\
\hline 1349 & Offline & Offline & Online & Brain & $\begin{array}{l}\text { Non- } \\
\text { digital }\end{array}$ & Non-digital & Online & Online \\
\hline 1350 & Offline & Offline & Online & Brain & $\begin{array}{l}\text { Non- } \\
\text { digital }\end{array}$ & Non-digital & Online & Offline \\
\hline
\end{tabular}




\begin{tabular}{|c|c|c|c|c|c|c|c|c|}
\hline 1351 & Offline & Offline & Online & Brain & $\begin{array}{l}\text { Non- } \\
\text { digital }\end{array}$ & Non-digital & Offline & Online \\
\hline 1352 & Offline & Offline & Online & Brain & $\begin{array}{l}\text { Non- } \\
\text { digital }\end{array}$ & Non-digital & Offline & Offline \\
\hline 1353 & Offline & Offline & Online & Brain & $\begin{array}{l}\text { Non- } \\
\text { digital }\end{array}$ & Blended & Online & Online \\
\hline 1354 & Offline & Offline & Online & Brain & $\begin{array}{l}\text { Non- } \\
\text { digital }\end{array}$ & Blended & Online & Offline \\
\hline 1355 & Offline & Offline & Online & Brain & $\begin{array}{l}\text { Non- } \\
\text { digital }\end{array}$ & Blended & Offline & Online \\
\hline 1356 & Offline & Offline & Online & Brain & $\begin{array}{l}\text { Non- } \\
\text { digital }\end{array}$ & Blended & Offline & Offline \\
\hline 1357 & Offline & Offline & Online & Brain & $\begin{array}{l}\text { Blend- } \\
\text { ed }\end{array}$ & Digital & Online & Online \\
\hline 1358 & Offline & Offline & Online & Brain & $\begin{array}{l}\text { Blend- } \\
\text { ed }\end{array}$ & Digital & Online & Offline \\
\hline 1359 & Offline & Offline & Online & Brain & $\begin{array}{l}\text { Blend- } \\
\text { ed }\end{array}$ & Digital & Offline & Online \\
\hline 1360 & Offline & Offline & Online & Brain & $\begin{array}{l}\text { Blend- } \\
\text { ed }\end{array}$ & Digital & Offline & Offline \\
\hline 1361 & Offline & Offline & Online & Brain & $\begin{array}{l}\text { Blend- } \\
\text { ed }\end{array}$ & Non-digital & Online & Online \\
\hline 1362 & Offline & Offline & Online & Brain & $\begin{array}{l}\text { Blend- } \\
\text { ed }\end{array}$ & Non-digital & Online & Offline \\
\hline 1363 & Offline & Offline & Online & Brain & $\begin{array}{l}\text { Blend- } \\
\text { ed }\end{array}$ & Non-digital & Offline & Online \\
\hline 1364 & Offline & Offline & Online & Brain & $\begin{array}{l}\text { Blend- } \\
\text { ed }\end{array}$ & Non-digital & Offline & Offline \\
\hline 1365 & Offline & Offline & Online & Brain & $\begin{array}{l}\text { Blend- } \\
\text { ed }\end{array}$ & Blended & Online & Online \\
\hline 1366 & Offline & Offline & Online & Brain & $\begin{array}{l}\text { Blend- } \\
\text { ed }\end{array}$ & Blended & Online & Offline \\
\hline 1367 & Offline & Offline & Online & Brain & $\begin{array}{l}\text { Blend- } \\
\text { ed }\end{array}$ & Blended & Offline & Online \\
\hline 1368 & Offline & Offline & Online & Brain & $\begin{array}{l}\text { Blend- } \\
\text { ed }\end{array}$ & Blended & Offline & Offline \\
\hline 1369 & Offline & Offline & Online & Brain $+d+n-d$ & Digital & Digital & Online & Online \\
\hline 1370 & Offline & Offline & Online & Brain $+d+n-d$ & Digital & Digital & Online & Offline \\
\hline 1371 & Offline & Offline & Online & Brain $+d+n-d$ & Digital & Digital & Offline & Online \\
\hline 1372 & Offline & Offline & Online & Brain + d + n-d & Digital & Digital & Offline & Offline \\
\hline 1373 & Offline & Offline & Online & Brain $+d+n-d$ & Digital & Non-digital & Online & Online \\
\hline 1374 & Offline & Offline & Online & Brain $+d+n-d$ & Digital & Non-digital & Online & Offline \\
\hline 1375 & Offline & Offline & Online & Brain $+d+n-d$ & Digital & Non-digital & Offline & Online \\
\hline 1376 & Offline & Offline & Online & Brain $+d+n-d$ & Digital & Non-digital & Offline & Offline \\
\hline 1377 & Offline & Offline & Online & Brain $+d+n-d$ & Digital & Blended & Online & Online \\
\hline 1378 & Offline & Offline & Online & Brain $+d+n-d$ & Digital & Blended & Online & Offline \\
\hline 1379 & Offline & Offline & Online & Brain $+d+n-d$ & Digital & Blended & Offline & Online \\
\hline 1380 & Offline & Offline & Online & Brain $+d+n-d$ & Digital & Blended & Offline & Offline \\
\hline 1381 & Offline & Offline & Online & Brain $+d+n-d$ & $\begin{array}{l}\text { Non- } \\
\text { digital }\end{array}$ & Digital & Online & Online \\
\hline 1382 & Offline & Offline & Online & Brain $+d+n-d$ & $\begin{array}{l}\text { Non- } \\
\text { digital }\end{array}$ & Digital & Online & Offline \\
\hline 1383 & Offline & Offline & Online & Brain $+d+n-d$ & $\begin{array}{l}\text { Non- } \\
\text { digital }\end{array}$ & Digital & Offline & Online \\
\hline 1384 & Offline & Offline & Online & Brain $+d+n-d$ & $\begin{array}{l}\text { Non- } \\
\text { digital }\end{array}$ & Digital & Offline & Offline \\
\hline 1385 & Offline & Offline & Online & Brain $+d+n-d$ & $\begin{array}{l}\text { Non- } \\
\text { digital }\end{array}$ & Non-digital & Online & Online \\
\hline 1386 & Offline & Offline & Online & Brain $+d+n-d$ & $\begin{array}{l}\text { Non- } \\
\text { digital }\end{array}$ & Non-digital & Online & Offline \\
\hline 1387 & Offline & Offline & Online & Brain $+d+n-d$ & $\begin{array}{l}\text { Non- } \\
\text { digital }\end{array}$ & Non-digital & Offline & Online \\
\hline 1388 & Offline & Offline & Online & Brain $+d+n-d$ & $\begin{array}{l}\text { Non- } \\
\text { digital }\end{array}$ & Non-digital & Offline & Offline \\
\hline
\end{tabular}




\begin{tabular}{|c|c|c|c|c|c|c|c|c|}
\hline 1389 & Offline & Offline & Online & Brain + d + n-d & $\begin{array}{l}\text { Non- } \\
\text { digital }\end{array}$ & Blended & Online & Online \\
\hline 1390 & Offline & Offline & Online & Brain $+d+n-d$ & $\begin{array}{l}\text { Non- } \\
\text { digital }\end{array}$ & Blended & Online & Offline \\
\hline 1391 & Offline & Offline & Online & Brain $+d+n-d$ & $\begin{array}{l}\text { Non- } \\
\text { digital }\end{array}$ & Blended & Offline & Online \\
\hline 1392 & Offline & Offline & Online & Brain $+d+n-d$ & $\begin{array}{l}\text { Non- } \\
\text { digital }\end{array}$ & Blended & Offline & Offline \\
\hline 1393 & Offline & Offline & Online & Brain $+d+n-d$ & $\begin{array}{l}\text { Blend- } \\
\text { ed }\end{array}$ & Digital & Online & Online \\
\hline 1394 & Offline & Offline & Online & Brain $+d+n-d$ & $\begin{array}{l}\text { Blend- } \\
\text { ed }\end{array}$ & Digital & Online & Offline \\
\hline 1395 & Offline & Offline & Online & Brain $+d+n-d$ & $\begin{array}{l}\text { Blend- } \\
\text { ed }\end{array}$ & Digital & Offline & Online \\
\hline 1396 & Offline & Offline & Online & Brain $+d+n-d$ & $\begin{array}{l}\text { Blend- } \\
\text { ed }\end{array}$ & Digital & Offline & Offline \\
\hline 1397 & Offline & Offline & Online & Brain $+d+n-d$ & $\begin{array}{l}\text { Blend- } \\
\text { ed }\end{array}$ & Non-digital & Online & Online \\
\hline 1398 & Offline & Offline & Online & Brain $+d+n-d$ & $\begin{array}{l}\text { Blend- } \\
\text { ed }\end{array}$ & Non-digital & Online & Offline \\
\hline 1399 & Offline & Offline & Online & Brain $+d+n-d$ & $\begin{array}{l}\text { Blend- } \\
\text { ed }\end{array}$ & Non-digital & Offline & Online \\
\hline 1400 & Offline & Offline & Online & Brain $+d+n-d$ & $\begin{array}{l}\text { Blend- } \\
\text { ed }\end{array}$ & Non-digital & Offline & Offline \\
\hline 1401 & Offline & Offline & Online & Brain $+d+n-d$ & $\begin{array}{l}\text { Blend- } \\
\text { ed }\end{array}$ & Blended & Online & Online \\
\hline 1402 & Offline & Offline & Online & Brain $+d+n-d$ & $\begin{array}{l}\text { Blend- } \\
\text { ed }\end{array}$ & Blended & Online & Offline \\
\hline 1403 & Offline & Offline & Online & Brain $+d+n-d$ & $\begin{array}{l}\text { Blend- } \\
\text { ed }\end{array}$ & Blended & Offline & Online \\
\hline 1404 & Offline & Offline & Online & Brain $+d+n-d$ & $\begin{array}{l}\text { Blend- } \\
\text { ed }\end{array}$ & Blended & Offline & Offline \\
\hline 1405 & Offline & Offline & Online & Brain + n-d & Digital & Digital & Online & Online \\
\hline 1406 & Offline & Offline & Online & Brain $+n-d$ & Digital & Digital & Online & Offline \\
\hline 1407 & Offline & Offline & Online & Brain + n-d & Digital & Digital & Offline & Online \\
\hline 1408 & Offline & Offline & Online & Brain $+n-d$ & Digital & Digital & Offline & Offline \\
\hline 1409 & Offline & Offline & Online & Brain $+n-d$ & Digital & Non-digital & Online & Online \\
\hline 1410 & Offline & Offline & Online & Brain + n-d & Digital & Non-digital & Online & Offline \\
\hline 1411 & Offline & Offline & Online & Brain + n-d & Digital & Non-digital & Offline & Online \\
\hline 1412 & Offline & Offline & Online & Brain $+n-d$ & Digital & Non-digital & Offline & Offline \\
\hline 1413 & Offline & Offline & Online & Brain + n-d & Digital & Blended & Online & Online \\
\hline 1414 & Offline & Offline & Online & Brain $+n-d$ & Digital & Blended & Online & Offline \\
\hline 1415 & Offline & Offline & Online & Brain $+n-d$ & Digital & Blended & Offline & Online \\
\hline 1416 & Offline & Offline & Online & Brain $+n-d$ & Digital & Blended & Offline & Offline \\
\hline 1417 & Offline & Offline & Online & Brain + n-d & $\begin{array}{l}\text { Non- } \\
\text { digital }\end{array}$ & Digital & Online & Online \\
\hline 1418 & Offline & Offline & Online & Brain + n-d & $\begin{array}{l}\text { Non- } \\
\text { digital }\end{array}$ & Digital & Online & Offline \\
\hline 1419 & Offline & Offline & Online & Brain + n-d & $\begin{array}{l}\text { Non- } \\
\text { digital }\end{array}$ & Digital & Offline & Online \\
\hline 1420 & Offline & Offline & Online & Brain + n-d & $\begin{array}{l}\text { Non- } \\
\text { digital }\end{array}$ & Digital & Offline & Offline \\
\hline 1421 & Offline & Offline & Online & Brain + n-d & $\begin{array}{l}\text { Non- } \\
\text { digital }\end{array}$ & Non-digital & Online & Online \\
\hline 1422 & Offline & Offline & Online & Brain + n-d & $\begin{array}{l}\text { Non- } \\
\text { digital }\end{array}$ & Non-digital & Online & Offline \\
\hline 1423 & Offline & Offline & Online & Brain + n-d & $\begin{array}{l}\text { Non- } \\
\text { digital }\end{array}$ & Non-digital & Offline & Online \\
\hline 1424 & Offline & Offline & Online & Brain + n-d & $\begin{array}{l}\text { Non- } \\
\text { digital }\end{array}$ & Non-digital & Offline & Offline \\
\hline 1425 & Offline & Offline & Online & Brain + n-d & $\begin{array}{l}\text { Non- } \\
\text { digital }\end{array}$ & Blended & Online & Online \\
\hline 1426 & Offline & Offline & Online & Brain + n-d & $\begin{array}{l}\text { Non- } \\
\text { digital }\end{array}$ & Blended & Online & Offline \\
\hline
\end{tabular}




\begin{tabular}{|c|c|c|c|c|c|c|c|c|}
\hline 1427 & Offline & Offline & Online & Brain + n-d & $\begin{array}{l}\text { Non- } \\
\text { digital }\end{array}$ & Blended & Offline & Online \\
\hline 1428 & Offline & Offline & Online & Brain + n-d & $\begin{array}{l}\text { Non- } \\
\text { digital }\end{array}$ & Blended & Offline & Offline \\
\hline 1429 & Offline & Offline & Online & Brain + n-d & $\begin{array}{l}\text { Blend- } \\
\text { ed }\end{array}$ & Digital & Online & Online \\
\hline 1430 & Offline & Offline & Online & Brain + n-d & $\begin{array}{l}\text { Blend- } \\
\text { ed }\end{array}$ & Digital & Online & Offline \\
\hline 1431 & Offline & Offline & Online & Brain + n-d & $\begin{array}{l}\text { Blend- } \\
\text { ed }\end{array}$ & Digital & Offline & Online \\
\hline 1432 & Offline & Offline & Online & Brain + n-d & $\begin{array}{l}\text { Blend- } \\
\text { ed }\end{array}$ & Digital & Offline & Offline \\
\hline 1433 & Offline & Offline & Online & Brain + n-d & $\begin{array}{l}\text { Blend- } \\
\text { ed }\end{array}$ & Non-digital & Online & Online \\
\hline 1434 & Offline & Offline & Online & Brain + n-d & $\begin{array}{l}\text { Blend- } \\
\text { ed }\end{array}$ & Non-digital & Online & Offline \\
\hline 1435 & Offline & Offline & Online & Brain + n-d & $\begin{array}{l}\text { Blend- } \\
\text { ed }\end{array}$ & Non-digital & Offline & Online \\
\hline 1436 & Offline & Offline & Online & Brain + n-d & $\begin{array}{l}\text { Blend- } \\
\text { ed }\end{array}$ & Non-digital & Offline & Offline \\
\hline 1437 & Offline & Offline & Online & Brain + n-d & $\begin{array}{l}\text { Blend- } \\
\text { ed }\end{array}$ & Blended & Online & Online \\
\hline 1438 & Offline & Offline & Online & Brain + n-d & $\begin{array}{l}\text { Blend- } \\
\text { ed }\end{array}$ & Blended & Online & Offline \\
\hline 1439 & Offline & Offline & Online & Brain + n-d & $\begin{array}{l}\text { Blend- } \\
\text { ed }\end{array}$ & Blended & Offline & Online \\
\hline 1440 & Offline & Offline & Online & Brain + n-d & $\begin{array}{l}\text { Blend- } \\
\text { ed }\end{array}$ & Blended & Offline & Offline \\
\hline 1441 & Offline & Offline & Offline & Brain + digital & Digital & Digital & Online & Online \\
\hline 1442 & Offline & Offline & Offline & Brain + digital & Digital & Digital & Online & Offline \\
\hline 1443 & Offline & Offline & Offline & Brain + digital & Digital & Digital & Offline & Online \\
\hline 1444 & Offline & Offline & Offline & Brain + digital & Digital & Digital & Offline & Offline \\
\hline 1445 & Offline & Offline & Offline & Brain + digital & Digital & Non-digital & Online & Online \\
\hline 1446 & Offline & Offline & Offline & Brain + digital & Digital & Non-digital & Online & Offline \\
\hline 1447 & Offline & Offline & Offline & Brain + digital & Digital & Non-digital & Offline & Online \\
\hline 1448 & Offline & Offline & Offline & Brain + digital & Digital & Non-digital & Offline & Offline \\
\hline 1449 & Offline & Offline & Offline & Brain + digital & Digital & Blended & Online & Online \\
\hline 1450 & Offline & Offline & Offline & Brain + digital & Digital & Blended & Online & Offline \\
\hline 1451 & Offline & Offline & Offline & Brain + digital & Digital & Blended & Offline & Online \\
\hline 1452 & Offline & Offline & Offline & Brain + digital & Digital & Blended & Offline & Offline \\
\hline 1453 & Offline & Offline & Offline & Brain + digital & $\begin{array}{l}\text { Non- } \\
\text { digital }\end{array}$ & Digital & Online & Online \\
\hline 1454 & Offline & Offline & Offline & Brain + digital & $\begin{array}{l}\text { Non- } \\
\text { digital }\end{array}$ & Digital & Online & Offline \\
\hline 1455 & Offline & Offline & Offline & Brain + digital & $\begin{array}{l}\text { Non- } \\
\text { digital }\end{array}$ & Digital & Offline & Online \\
\hline 1456 & Offline & Offline & Offline & Brain + digital & $\begin{array}{l}\text { Non- } \\
\text { digital }\end{array}$ & Digital & Offline & Offline \\
\hline 1457 & Offline & Offline & Offline & Brain + digital & $\begin{array}{l}\text { Non- } \\
\text { digital }\end{array}$ & Non-digital & Online & Online \\
\hline 1458 & Offline & Offline & Offline & Brain + digital & $\begin{array}{l}\text { Non- } \\
\text { digital }\end{array}$ & Non-digital & Online & Offline \\
\hline 1459 & Offline & Offline & Offline & Brain + digital & $\begin{array}{l}\text { Non- } \\
\text { digital }\end{array}$ & Non-digital & Offline & Online \\
\hline 1460 & Offline & Offline & Offline & Brain + digital & $\begin{array}{l}\text { Non- } \\
\text { digital }\end{array}$ & Non-digital & Offline & Offline \\
\hline 1461 & Offline & Offline & Offline & Brain + digital & $\begin{array}{l}\text { Non- } \\
\text { digital }\end{array}$ & Blended & Online & Online \\
\hline 1462 & Offline & Offline & Offline & Brain + digital & $\begin{array}{l}\text { Non- } \\
\text { digital }\end{array}$ & Blended & Online & Offline \\
\hline 1463 & Offline & Offline & Offline & Brain + digital & $\begin{array}{l}\text { Non- } \\
\text { digital }\end{array}$ & Blended & Offline & Online \\
\hline 1464 & Offline & Offline & Offline & Brain + digital & $\begin{array}{l}\text { Non- } \\
\text { digital }\end{array}$ & Blended & Offline & Offline \\
\hline
\end{tabular}




\begin{tabular}{|c|c|c|c|c|c|c|c|c|}
\hline 1465 & Offline & Offline & Offline & Brain + digital & $\begin{array}{l}\text { Blend- } \\
\text { ed }\end{array}$ & Digital & Online & Online \\
\hline 1466 & Offline & Offline & Offline & Brain + digital & $\begin{array}{l}\text { Blend- } \\
\text { ed }\end{array}$ & Digital & Online & Offline \\
\hline 1467 & Offline & Offline & Offline & Brain + digital & $\begin{array}{l}\text { Blend- } \\
\text { ed }\end{array}$ & Digital & Offline & Online \\
\hline 1468 & Offline & Offline & Offline & Brain + digital & $\begin{array}{l}\text { Blend- } \\
\text { ed }\end{array}$ & Digital & Offline & Offline \\
\hline 1469 & Offline & Offline & Offline & Brain + digital & $\begin{array}{l}\text { Blend- } \\
\text { ed }\end{array}$ & Non-digital & Online & Online \\
\hline 1470 & Offline & Offline & Offline & Brain + digital & $\begin{array}{l}\text { Blend- } \\
\text { ed }\end{array}$ & Non-digital & Online & Offline \\
\hline 1471 & Offline & Offline & Offline & Brain + digital & $\begin{array}{l}\text { Blend- } \\
\text { ed }\end{array}$ & Non-digital & Offline & Online \\
\hline 1472 & Offline & Offline & Offline & Brain + digital & $\begin{array}{l}\text { Blend- } \\
\text { ed }\end{array}$ & Non-digital & Offline & Offline \\
\hline 1473 & Offline & Offline & Offline & Brain + digital & $\begin{array}{l}\text { Blend- } \\
\text { ed }\end{array}$ & Blended & Online & Online \\
\hline 1474 & Offline & Offline & Offline & Brain + digital & $\begin{array}{l}\text { Blend- } \\
\text { ed }\end{array}$ & Blended & Online & Offline \\
\hline 1475 & Offline & Offline & Offline & Brain + digital & $\begin{array}{l}\text { Blend- } \\
\text { ed }\end{array}$ & Blended & Offline & Online \\
\hline 1476 & Offline & Offline & Offline & Brain + digital & $\begin{array}{l}\text { Blend- } \\
\text { ed }\end{array}$ & Blended & Offline & Offline \\
\hline 1477 & Offline & Offline & Offline & Brain & Digital & Digital & Online & Online \\
\hline 1478 & Offline & Offline & Offline & Brain & Digital & Digital & Online & Offline \\
\hline 1479 & Offline & Offline & Offline & Brain & Digital & Digital & Offline & Online \\
\hline 1480 & Offline & Offline & Offline & Brain & Digital & Digital & Offline & Offline \\
\hline 1481 & Offline & Offline & Offline & Brain & Digital & Non-digital & Online & Online \\
\hline 1482 & Offline & Offline & Offline & Brain & Digital & Non-digital & Online & Offline \\
\hline 1483 & Offline & Offline & Offline & Brain & Digital & Non-digital & Offline & Online \\
\hline 1484 & Offline & Offline & Offline & Brain & Digital & Non-digital & Offline & Offline \\
\hline 1485 & Offline & Offline & Offline & Brain & Digital & Blended & Online & Online \\
\hline 1486 & Offline & Offline & Offline & Brain & Digital & Blended & Online & Offline \\
\hline 1487 & Offline & Offline & Offline & Brain & Digital & Blended & Offline & Online \\
\hline 1488 & Offline & Offline & Offline & Brain & Digital & Blended & Offline & Offline \\
\hline 1489 & Offline & Offline & Offline & Brain & $\begin{array}{l}\text { Non- } \\
\text { diaital }\end{array}$ & Digital & Online & Online \\
\hline 1490 & Offline & Offline & Offline & Brain & $\begin{array}{l}\text { Non- } \\
\text { digital }\end{array}$ & Digital & Online & Offline \\
\hline 1491 & Offline & Offline & Offline & Brain & $\begin{array}{l}\text { Non- } \\
\text { diaital }\end{array}$ & Digital & Offline & Online \\
\hline 1492 & Offline & Offline & Offline & Brain & $\begin{array}{l}\text { Non- } \\
\text { diaital }\end{array}$ & Digital & Offline & Offline \\
\hline 1493 & Offline & Offline & Offline & Brain & $\begin{array}{l}\text { Non- } \\
\text { digital }\end{array}$ & Non-digital & Online & Online \\
\hline 1494 & Offline & Offline & Offline & Brain & $\begin{array}{l}\text { Non- } \\
\text { diaital }\end{array}$ & Non-digital & Online & Offline \\
\hline 1495 & Offline & Offline & Offline & Brain & $\begin{array}{l}\text { Non- } \\
\text { digital }\end{array}$ & Non-digital & Offline & Online \\
\hline 1496 & Offline & Offline & Offline & Brain & $\begin{array}{l}\text { Non- } \\
\text { diaital }\end{array}$ & Non-digital & Offline & Offline \\
\hline 1497 & Offline & Offline & Offline & Brain & $\begin{array}{l}\text { Non- } \\
\text { digital }\end{array}$ & Blended & Online & Online \\
\hline 1498 & Offline & Offline & Offline & Brain & $\begin{array}{l}\text { Non- } \\
\text { digital }\end{array}$ & Blended & Online & Offline \\
\hline 1499 & Offline & Offline & Offline & Brain & $\begin{array}{l}\text { Non- } \\
\text { digital }\end{array}$ & Blended & Offline & Online \\
\hline 1500 & Offline & Offline & Offline & Brain & $\begin{array}{l}\text { Non- } \\
\text { digital }\end{array}$ & Blended & Offline & Offline \\
\hline 1501 & Offline & Offline & Offline & Brain & $\begin{array}{l}\text { Blend- } \\
\text { ed }\end{array}$ & Digital & Online & Online \\
\hline 1502 & Offline & Offline & Offline & Brain & $\begin{array}{l}\text { Blend- } \\
\text { ed }\end{array}$ & Digital & Online & Offline \\
\hline
\end{tabular}




\begin{tabular}{|c|c|c|c|c|c|c|c|c|}
\hline 1503 & Offline & Offline & Offline & Brain & $\begin{array}{l}\text { Blend- } \\
\text { ed }\end{array}$ & Digital & Offline & Online \\
\hline 1504 & Offline & Offline & Offline & Brain & $\begin{array}{l}\text { Blend- } \\
\text { ed }\end{array}$ & Digital & Offline & Offline \\
\hline 1505 & Offline & Offline & Offline & Brain & $\begin{array}{l}\text { Blend- } \\
\text { ed }\end{array}$ & Non-digital & Online & Online \\
\hline 1506 & Offline & Offline & Offline & Brain & $\begin{array}{l}\text { Blend- } \\
\text { ed }\end{array}$ & Non-digital & Online & Offline \\
\hline 1507 & Offline & Offline & Offline & Brain & $\begin{array}{l}\text { Blend- } \\
\text { ed }\end{array}$ & Non-digital & Offline & Online \\
\hline 1508 & Offline & Offline & Offline & Brain & $\begin{array}{l}\text { Blend- } \\
\text { ed }\end{array}$ & Non-digital & Offline & Offline \\
\hline 1509 & Offline & Offline & Offline & Brain & $\begin{array}{l}\text { Blend- } \\
\text { ed }\end{array}$ & Blended & Online & Online \\
\hline 1510 & Offline & Offline & Offline & Brain & $\begin{array}{l}\text { Blend- } \\
\text { ed }\end{array}$ & Blended & Online & Offline \\
\hline 1511 & Offline & Offline & Offline & Brain & $\begin{array}{l}\text { Blend- } \\
\text { ed }\end{array}$ & Blended & Offline & Online \\
\hline 1512 & Offline & Offline & Offline & Brain & $\begin{array}{l}\text { Blend- } \\
\text { ed }\end{array}$ & Blended & Offline & Offline \\
\hline 1513 & Offline & Offline & Offline & Brain $+d+n-d$ & Digital & Digital & Online & Online \\
\hline 1514 & Offline & Offline & Offline & Brain +d + n-d & Digital & Digital & Online & Offline \\
\hline 1515 & Offline & Offline & Offline & Brain $+d+n-d$ & Digital & Digital & Offline & Online \\
\hline 1516 & Offline & Offline & Offline & Brain $+d+n-d$ & Digital & Digital & Offline & Offline \\
\hline 1517 & Offline & Offline & Offline & Brain + d + n-d & Digital & Non-digital & Online & Online \\
\hline 1518 & Offline & Offline & Offline & Brain $+d+n-d$ & Digital & Non-digital & Online & Offline \\
\hline 1519 & Offline & Offline & Offline & Brain $+d+n-d$ & Digital & Non-digital & Offline & Online \\
\hline 1520 & Offline & Offline & Offline & Brain + d + n-d & Digital & Non-digital & Offline & Offline \\
\hline 1521 & Offline & Offline & Offline & Brain + d + n-d & Digital & Blended & Online & Online \\
\hline 1522 & Offline & Offline & Offline & Brain $+d+n-d$ & Digital & Blended & Online & Offline \\
\hline 1523 & Offline & Offline & Offline & Brain + d + n-d & Digital & Blended & Offline & Online \\
\hline 1524 & Offline & Offline & Offline & Brain $+d+n-d$ & Digital & Blended & Offline & Offline \\
\hline 1525 & Offline & Offline & Offline & Brain $+d+n-d$ & $\begin{array}{l}\text { Non- } \\
\text { digital }\end{array}$ & Digital & Online & Online \\
\hline 1526 & Offline & Offline & Offline & Brain $+d+n-d$ & $\begin{array}{l}\text { Non- } \\
\text { digital }\end{array}$ & Digital & Online & Offline \\
\hline 1527 & Offline & Offline & Offline & Brain $+d+n-d$ & $\begin{array}{l}\text { Non- } \\
\text { digital }\end{array}$ & Digital & Offline & Online \\
\hline 1528 & Offline & Offline & Offline & Brain $+d+n-d$ & $\begin{array}{l}\text { Non- } \\
\text { digital }\end{array}$ & Digital & Offline & Offline \\
\hline 1529 & Offline & Offline & Offline & Brain $+d+n-d$ & $\begin{array}{l}\text { Non- } \\
\text { digital }\end{array}$ & Non-digital & Online & Online \\
\hline 1530 & Offline & Offline & Offline & Brain $+d+n-d$ & $\begin{array}{l}\text { Non- } \\
\text { digital }\end{array}$ & Non-digital & Online & Offline \\
\hline 1531 & Offline & Offline & Offline & Brain $+d+n-d$ & $\begin{array}{l}\text { Non- } \\
\text { diqital }\end{array}$ & Non-digital & Offline & Online \\
\hline 1532 & Offline & Offline & Offline & Brain $+d+n-d$ & $\begin{array}{l}\text { Non- } \\
\text { digital }\end{array}$ & Non-digital & Offline & Offline \\
\hline 1533 & Offline & Offline & Offline & Brain $+d+n-d$ & $\begin{array}{l}\text { Non- } \\
\text { digital }\end{array}$ & Blended & Online & Online \\
\hline 1534 & Offline & Offline & Offline & Brain $+d+n-d$ & $\begin{array}{l}\text { Non- } \\
\text { digital }\end{array}$ & Blended & Online & Offline \\
\hline 1535 & Offline & Offline & Offline & Brain + d + n-d & $\begin{array}{l}\text { Non- } \\
\text { digital }\end{array}$ & Blended & Offline & Online \\
\hline 1536 & Offline & Offline & Offline & Brain + d + n-d & $\begin{array}{l}\text { Non- } \\
\text { diqital }\end{array}$ & Blended & Offline & Offline \\
\hline 1537 & Offline & Offline & Offline & Brain $+d+n-d$ & $\begin{array}{l}\text { Blend- } \\
\text { ed }\end{array}$ & Digital & Online & Online \\
\hline 1538 & Offline & Offline & Offline & Brain $+d+n-d$ & $\begin{array}{l}\text { Blend- } \\
\text { ed }\end{array}$ & Digital & Online & Offline \\
\hline 1539 & Offline & Offline & Offline & Brain + d + n-d & $\begin{array}{l}\text { Blend- } \\
\text { ed }\end{array}$ & Digital & Offline & Online \\
\hline 1540 & Offline & Offline & Offline & Brain + d + n-d & $\begin{array}{l}\text { Blend- } \\
\text { ed }\end{array}$ & Digital & Offline & Offline \\
\hline
\end{tabular}




\begin{tabular}{|c|c|c|c|c|c|c|c|c|}
\hline 1541 & Offline & Offline & Offline & Brain $+d+n-d$ & $\begin{array}{l}\text { Blend- } \\
\text { ed }\end{array}$ & Non-digital & Online & Online \\
\hline 1542 & Offline & Offline & Offline & Brain $+d+n-d$ & $\begin{array}{l}\text { Blend- } \\
\text { ed }\end{array}$ & Non-digital & Online & Offline \\
\hline 1543 & Offline & Offline & Offline & Brain $+d+n-d$ & $\begin{array}{l}\text { Blend- } \\
\text { ed }\end{array}$ & Non-digital & Offline & Online \\
\hline 1544 & Offline & Offline & Offline & Brain $+d+n-d$ & $\begin{array}{l}\text { Blend- } \\
\text { ed }\end{array}$ & Non-digital & Offline & Offline \\
\hline 1545 & Offline & Offline & Offline & Brain $+d+n-d$ & $\begin{array}{l}\text { Blend- } \\
\text { ed }\end{array}$ & Blended & Online & Online \\
\hline 1546 & Offline & Offline & Offline & Brain $+d+n-d$ & $\begin{array}{l}\text { Blend- } \\
\text { ed }\end{array}$ & Blended & Online & Offline \\
\hline 1547 & Offline & Offline & Offline & Brain $+d+n-d$ & $\begin{array}{l}\text { Blend- } \\
\text { ed }\end{array}$ & Blended & Offline & Online \\
\hline 1548 & Offline & Offline & Offline & Brain $+d+n-d$ & $\begin{array}{l}\text { Blend- } \\
\text { ed }\end{array}$ & Blended & Offline & Offline \\
\hline 1549 & Offline & Offline & Offline & Brain + n-d & Digital & Digital & Online & Online \\
\hline 1550 & Offline & Offline & Offline & Brain $+n-d$ & Digital & Digital & Online & Offline \\
\hline 1551 & Offline & Offline & Offline & Brain + n-d & Digital & Digital & Offline & Online \\
\hline 1552 & Offline & Offline & Offline & Brain $+n-d$ & Digital & Digital & Offline & Offline \\
\hline 1553 & Offline & Offline & Offline & Brain $+n-d$ & Digital & Non-digital & Online & Online \\
\hline 1554 & Offline & Offline & Offline & Brain $+n-d$ & Digital & Non-digital & Online & Offline \\
\hline 1555 & Offline & Offline & Offline & Brain $+n-d$ & Digital & Non-digital & Offline & Online \\
\hline 1556 & Offline & Offline & Offline & Brain $+n-d$ & Digital & Non-digital & Offline & Offline \\
\hline 1557 & Offline & Offline & Offline & Brain $+n-d$ & Digital & Blended & Online & Online \\
\hline 1558 & Offline & Offline & Offline & Brain + n-d & Digital & Blended & Online & Offline \\
\hline 1559 & Offline & Offline & Offline & Brain $+n-d$ & Digital & Blended & Offline & Online \\
\hline 1560 & Offline & Offline & Offline & Brain + n-d & Digital & Blended & Offline & Offline \\
\hline 1561 & Offline & Offline & Offline & Brain + n-d & $\begin{array}{l}\text { Non- } \\
\text { digital }\end{array}$ & Digital & Online & Online \\
\hline 1562 & Offline & Offline & Offline & Brain + n-d & $\begin{array}{l}\text { Non- } \\
\text { digital }\end{array}$ & Digital & Online & Offline \\
\hline 1563 & Offline & Offline & Offline & Brain + n-d & $\begin{array}{l}\text { Non- } \\
\text { digital }\end{array}$ & Digital & Offline & Online \\
\hline 1564 & Offline & Offline & Offline & Brain $+n-d$ & $\begin{array}{l}\text { Non- } \\
\text { digital }\end{array}$ & Digital & Offline & Offline \\
\hline 1565 & Offline & Offline & Offline & Brain $+n-d$ & $\begin{array}{l}\text { Non- } \\
\text { digital }\end{array}$ & Non-digital & Online & Online \\
\hline 1566 & Offline & Offline & Offline & Brain + n-d & $\begin{array}{l}\text { Non- } \\
\text { digital }\end{array}$ & Non-digital & Online & Offline \\
\hline 1567 & Offline & Offline & Offline & Brain $+n-d$ & $\begin{array}{l}\text { Non- } \\
\text { digital }\end{array}$ & Non-digital & Offline & Online \\
\hline 1568 & Offline & Offline & Offline & Brain $+n-d$ & $\begin{array}{l}\text { Non- } \\
\text { digital }\end{array}$ & Non-digital & Offline & Offline \\
\hline 1569 & Offline & Offline & Offline & Brain $+n-d$ & $\begin{array}{l}\text { Non- } \\
\text { digital }\end{array}$ & Blended & Online & Online \\
\hline 1570 & Offline & Offline & Offline & Brain + n-d & $\begin{array}{l}\text { Non- } \\
\text { digital }\end{array}$ & Blended & Online & Offline \\
\hline 1571 & Offline & Offline & Offline & Brain $+n-d$ & $\begin{array}{l}\text { Non- } \\
\text { digital }\end{array}$ & Blended & Offline & Online \\
\hline 1572 & Offline & Offline & Offline & Brain $+n-d$ & $\begin{array}{l}\text { Non- } \\
\text { digital }\end{array}$ & Blended & Offline & Offline \\
\hline 1573 & Offline & Offline & Offline & Brain + n-d & $\begin{array}{l}\text { Blend- } \\
\text { ed }\end{array}$ & Digital & Online & Online \\
\hline 1574 & Offline & Offline & Offline & Brain + n-d & $\begin{array}{l}\text { Blend- } \\
\text { ed }\end{array}$ & Digital & Online & Offline \\
\hline 1575 & Offline & Offline & Offline & Brain $+n-d$ & $\begin{array}{l}\text { Blend- } \\
\text { ed }\end{array}$ & Digital & Offline & Online \\
\hline 1576 & Offline & Offline & Offline & Brain + n-d & $\begin{array}{l}\text { Blend- } \\
\text { ed }\end{array}$ & Digital & Offline & Offline \\
\hline 1577 & Offline & Offline & Offline & Brain + n-d & $\begin{array}{l}\text { Blend- } \\
\text { ed }\end{array}$ & Non-digital & Online & Online \\
\hline 1578 & Offline & Offline & Offline & Brain $+n-d$ & $\begin{array}{l}\text { Blend- } \\
\text { ed }\end{array}$ & Non-digital & Online & Offline \\
\hline
\end{tabular}




\begin{tabular}{|c|c|c|c|c|c|c|c|c|}
\hline 1579 & Offline & Offline & Offline & Brain + n-d & $\begin{array}{l}\text { Blend- } \\
\text { ed }\end{array}$ & Non-digital & Offline & Online \\
\hline 1580 & Offline & Offline & Offline & Brain + n-d & $\begin{array}{l}\text { Blend- } \\
\text { ed }\end{array}$ & Non-digital & Offline & Offline \\
\hline 1581 & Offline & Offline & Offline & Brain + n-d & $\begin{array}{l}\text { Blend- } \\
\text { ed }\end{array}$ & Blended & Online & Online \\
\hline 1582 & Offline & Offline & Offline & Brain + n-d & $\begin{array}{l}\text { Blend- } \\
\text { ed }\end{array}$ & Blended & Online & Offline \\
\hline 1583 & Offline & Offline & Offline & Brain + n-d & $\begin{array}{l}\text { Blend- } \\
\text { ed }\end{array}$ & Blended & Offline & Online \\
\hline 1584 & Offline & Offline & Offline & Brain + n-d & $\begin{array}{l}\text { Blend- } \\
\text { ed }\end{array}$ & Blended & Offline & Offline \\
\hline 1585 & Offline & Offline & Blended & Brain + digital & Digital & Digital & Online & Online \\
\hline 1586 & Offline & Offline & Blended & Brain + digital & Digital & Digital & Online & Offline \\
\hline 1587 & Offline & Offline & Blended & Brain + digital & Digital & Digital & Offline & Online \\
\hline 1588 & Offline & Offline & Blended & Brain + digital & Digital & Digital & Offline & Offline \\
\hline 1589 & Offline & Offline & Blended & Brain + digital & Digital & Non-digital & Online & Online \\
\hline 1590 & Offline & Offline & Blended & Brain + digital & Digital & Non-digital & Online & Offline \\
\hline 1591 & Offline & Offline & Blended & Brain + digital & Digital & Non-digital & Offline & Online \\
\hline 1592 & Offline & Offline & Blended & Brain + digital & Digital & Non-digital & Offline & Offline \\
\hline 1593 & Offline & Offline & Blended & Brain + digital & Digital & Blended & Online & Online \\
\hline 1594 & Offline & Offline & Blended & Brain + digital & Digital & Blended & Online & Offline \\
\hline 1595 & Offline & Offline & Blended & Brain + digital & Digital & Blended & Offline & Online \\
\hline 1596 & Offline & Offline & Blended & Brain + digital & Digital & Blended & Offline & Offline \\
\hline 1597 & Offline & Offline & Blended & Brain + digital & $\begin{array}{l}\text { Non- } \\
\text { digital }\end{array}$ & Digital & Online & Online \\
\hline 1598 & Offline & Offline & Blended & Brain + digital & $\begin{array}{l}\text { Non- } \\
\text { digital }\end{array}$ & Digital & Online & Offline \\
\hline 1599 & Offline & Offline & Blended & Brain + digital & $\begin{array}{l}\text { Non- } \\
\text { digital }\end{array}$ & Digital & Offline & Online \\
\hline 1600 & Offline & Offline & Blended & Brain + digital & $\begin{array}{l}\text { Non- } \\
\text { digital }\end{array}$ & Digital & Offline & Offline \\
\hline 1601 & Offline & Offline & Blended & Brain + digital & $\begin{array}{l}\text { Non- } \\
\text { digital }\end{array}$ & Non-digital & Online & Online \\
\hline 1602 & Offline & Offline & Blended & Brain + digital & $\begin{array}{l}\text { Non- } \\
\text { digital }\end{array}$ & Non-digital & Online & Offline \\
\hline 1603 & Offline & Offline & Blended & Brain + digital & $\begin{array}{l}\text { Non- } \\
\text { digital }\end{array}$ & Non-digital & Offline & Online \\
\hline 1604 & Offline & Offline & Blended & Brain + digital & $\begin{array}{l}\text { Non- } \\
\text { digital }\end{array}$ & Non-digital & Offline & Offline \\
\hline 1605 & Offline & Offline & Blended & Brain + digital & $\begin{array}{l}\text { Non- } \\
\text { digital }\end{array}$ & Blended & Online & Online \\
\hline 1606 & Offline & Offline & Blended & Brain + digital & $\begin{array}{l}\text { Non- } \\
\text { digital }\end{array}$ & Blended & Online & Offline \\
\hline 1607 & Offline & Offline & Blended & Brain + digital & $\begin{array}{l}\text { Non- } \\
\text { digital }\end{array}$ & Blended & Offline & Online \\
\hline 1608 & Offline & Offline & Blended & Brain + digital & $\begin{array}{l}\text { Non- } \\
\text { digital }\end{array}$ & Blended & Offline & Offline \\
\hline 1609 & Offline & Offline & Blended & Brain + digital & $\begin{array}{l}\text { Blend- } \\
\text { ed }\end{array}$ & Digital & Online & Online \\
\hline 1610 & Offline & Offline & Blended & Brain + digital & $\begin{array}{l}\text { Blend- } \\
\text { ed }\end{array}$ & Digital & Online & Offline \\
\hline 1611 & Offline & Offline & Blended & Brain + digital & $\begin{array}{l}\text { Blend- } \\
\text { ed }\end{array}$ & Digital & Offline & Online \\
\hline 1612 & Offline & Offline & Blended & Brain + digital & $\begin{array}{l}\text { Blend- } \\
\text { ed }\end{array}$ & Digital & Offline & Offline \\
\hline 1613 & Offline & Offline & Blended & Brain + digital & $\begin{array}{l}\text { Blend- } \\
\text { ed }\end{array}$ & Non-digital & Online & Online \\
\hline 1614 & Offline & Offline & Blended & Brain + digital & $\begin{array}{l}\text { Blend- } \\
\text { ed }\end{array}$ & Non-digital & Online & Offline \\
\hline 1615 & Offline & Offline & Blended & Brain + digital & $\begin{array}{l}\text { Blend- } \\
\text { ed }\end{array}$ & Non-digital & Offline & Online \\
\hline 1616 & Offline & Offline & Blended & Brain + digital & $\begin{array}{l}\text { Blend- } \\
\text { ed }\end{array}$ & Non-digital & Offline & Offline \\
\hline
\end{tabular}




\begin{tabular}{|c|c|c|c|c|c|c|c|c|}
\hline 1617 & Offline & Offline & Blended & Brain + digital & $\begin{array}{l}\text { Blend- } \\
\text { ed }\end{array}$ & Blended & Online & Online \\
\hline 1618 & Offline & Offline & Blended & Brain + digital & $\begin{array}{l}\text { Blend- } \\
\text { ed }\end{array}$ & Blended & Online & Offline \\
\hline 1619 & Offline & Offline & Blended & Brain + digital & $\begin{array}{l}\text { Blend- } \\
\text { ed }\end{array}$ & Blended & Offline & Online \\
\hline 1620 & Offline & Offline & Blended & Brain + digital & $\begin{array}{l}\text { Blend- } \\
\text { ed }\end{array}$ & Blended & Offline & Offline \\
\hline 1621 & Offline & Offline & Blended & Brain & Digital & Digital & Online & Online \\
\hline 1622 & Offline & Offline & Blended & Brain & Digital & Digital & Online & Offline \\
\hline 1623 & Offline & Offline & Blended & Brain & Digital & Digital & Offline & Online \\
\hline 1624 & Offline & Offline & Blended & Brain & Digital & Digital & Offline & Offline \\
\hline 1625 & Offline & Offline & Blended & Brain & Digital & Non-digital & Online & Online \\
\hline 1626 & Offline & Offline & Blended & Brain & Digital & Non-digital & Online & Offline \\
\hline 1627 & Offline & Offline & Blended & Brain & Digital & Non-digital & Offline & Online \\
\hline 1628 & Offline & Offline & Blended & Brain & Digital & Non-digital & Offline & Offline \\
\hline 1629 & Offline & Offline & Blended & Brain & Digital & Blended & Online & Online \\
\hline 1630 & Offline & Offline & Blended & Brain & Digital & Blended & Online & Offline \\
\hline 1631 & Offline & Offline & Blended & Brain & Digital & Blended & Offline & Online \\
\hline 1632 & Offline & Offline & Blended & Brain & Digital & Blended & Offline & Offline \\
\hline 1633 & Offline & Offline & Blended & Brain & $\begin{array}{l}\text { Non- } \\
\text { digital }\end{array}$ & Digital & Online & Online \\
\hline 1634 & Offline & Offline & Blended & Brain & $\begin{array}{l}\text { Non- } \\
\text { digital }\end{array}$ & Digital & Online & Offline \\
\hline 1635 & Offline & Offline & Blended & Brain & $\begin{array}{l}\text { Non- } \\
\text { digital }\end{array}$ & Digital & Offline & Online \\
\hline 1636 & Offline & Offline & Blended & Brain & $\begin{array}{l}\text { Non- } \\
\text { digital }\end{array}$ & Digital & Offline & Offline \\
\hline 1637 & Offline & Offline & Blended & Brain & $\begin{array}{l}\text { Non- } \\
\text { digital }\end{array}$ & Non-digital & Online & Online \\
\hline 1638 & Offline & Offline & Blended & Brain & $\begin{array}{l}\text { Non- } \\
\text { digital }\end{array}$ & Non-digital & Online & Offline \\
\hline 1639 & Offline & Offline & Blended & Brain & $\begin{array}{l}\text { Non- } \\
\text { digital }\end{array}$ & Non-digital & Offline & Online \\
\hline 1640 & Offline & Offline & Blended & Brain & $\begin{array}{l}\text { Non- } \\
\text { digital }\end{array}$ & Non-digital & Offline & Offline \\
\hline 1641 & Offline & Offline & Blended & Brain & $\begin{array}{l}\text { Non- } \\
\text { digital }\end{array}$ & Blended & Online & Online \\
\hline 1642 & Offline & Offline & Blended & Brain & $\begin{array}{l}\text { Non- } \\
\text { digital }\end{array}$ & Blended & Online & Offline \\
\hline 1643 & Offline & Offline & Blended & Brain & $\begin{array}{l}\text { Non- } \\
\text { digital }\end{array}$ & Blended & Offline & Online \\
\hline 1644 & Offline & Offline & Blended & Brain & $\begin{array}{l}\text { Non- } \\
\text { diaital }\end{array}$ & Blended & Offline & Offline \\
\hline 1645 & Offline & Offline & Blended & Brain & $\begin{array}{l}\text { Blend- } \\
\text { ed }\end{array}$ & Digital & Online & Online \\
\hline 1646 & Offline & Offline & Blended & Brain & $\begin{array}{l}\text { Blend- } \\
\text { ed }\end{array}$ & Digital & Online & Offline \\
\hline 1647 & Offline & Offline & Blended & Brain & $\begin{array}{l}\text { Blend- } \\
\text { ed }\end{array}$ & Digital & Offline & Online \\
\hline 1648 & Offline & Offline & Blended & Brain & $\begin{array}{l}\text { Blend- } \\
\text { ed }\end{array}$ & Digital & Offline & Offline \\
\hline 1649 & Offline & Offline & Blended & Brain & $\begin{array}{l}\text { Blend- } \\
\text { ed }\end{array}$ & Non-digital & Online & Online \\
\hline 1650 & Offline & Offline & Blended & Brain & $\begin{array}{l}\text { Blend- } \\
\text { ed }\end{array}$ & Non-digital & Online & Offline \\
\hline 1651 & Offline & Offline & Blended & Brain & $\begin{array}{l}\text { Blend- } \\
\text { ed }\end{array}$ & Non-digital & Offline & Online \\
\hline 1652 & Offline & Offline & Blended & Brain & $\begin{array}{l}\text { Blend- } \\
\text { ed }\end{array}$ & Non-digital & Offline & Offline \\
\hline 1653 & Offline & Offline & Blended & Brain & $\begin{array}{l}\text { Blend- } \\
\text { ed }\end{array}$ & Blended & Online & Online \\
\hline 1654 & Offline & Offline & Blended & Brain & $\begin{array}{l}\text { Blend- } \\
\text { ed }\end{array}$ & Blended & Online & Offline \\
\hline
\end{tabular}




\begin{tabular}{|c|c|c|c|c|c|c|c|c|}
\hline 1655 & Offline & Offline & Blended & Brain & $\begin{array}{l}\text { Blend- } \\
\text { ed }\end{array}$ & Blended & Offline & Online \\
\hline 1656 & Offline & Offline & Blended & Brain & $\begin{array}{l}\text { Blend- } \\
\text { ed }\end{array}$ & Blended & Offline & Offline \\
\hline 1657 & Offline & Offline & Blended & Brain $+d+n-d$ & Digital & Digital & Online & Online \\
\hline 1658 & Offline & Offline & Blended & Brain $+d+n-d$ & Digital & Digital & Online & Offline \\
\hline 1659 & Offline & Offline & Blended & Brain $+d+n-d$ & Digital & Digital & Offline & Online \\
\hline 1660 & Offline & Offline & Blended & Brain $+d+n-d$ & Digital & Digital & Offline & Offline \\
\hline 1661 & Offline & Offline & Blended & Brain $+d+n-d$ & Digital & Non-digital & Online & Online \\
\hline 1662 & Offline & Offline & Blended & Brain $+d+n-d$ & Digital & Non-digital & Online & Offline \\
\hline 1663 & Offline & Offline & Blended & Brain $+d+n-d$ & Digital & Non-digital & Offline & Online \\
\hline 1664 & Offline & Offline & Blended & Brain $+d+n-d$ & Digital & Non-digital & Offline & Offline \\
\hline 1665 & Offline & Offline & Blended & Brain $+d+n-d$ & Digital & Blended & Online & Online \\
\hline 1666 & Offline & Offline & Blended & Brain $+d+n-d$ & Digital & Blended & Online & Offline \\
\hline 1667 & Offline & Offline & Blended & Brain $+d+n-d$ & Digital & Blended & Offline & Online \\
\hline 1668 & Offline & Offline & Blended & Brain $+d+n-d$ & Digital & Blended & Offline & Offline \\
\hline 1669 & Offline & Offline & Blended & Brain $+d+n-d$ & $\begin{array}{l}\text { Non- } \\
\text { digital }\end{array}$ & Digital & Online & Online \\
\hline 1670 & Offline & Offline & Blended & Brain $+d+n-d$ & $\begin{array}{l}\text { Non- } \\
\text { digital }\end{array}$ & Digital & Online & Offline \\
\hline 1671 & Offline & Offline & Blended & Brain $+d+n-d$ & $\begin{array}{l}\text { Non- } \\
\text { digital }\end{array}$ & Digital & Offline & Online \\
\hline 1672 & Offline & Offline & Blended & Brain $+d+n-d$ & $\begin{array}{l}\text { Non- } \\
\text { digital }\end{array}$ & Digital & Offline & Offline \\
\hline 1673 & Offline & Offline & Blended & Brain $+d+n-d$ & $\begin{array}{l}\text { Non- } \\
\text { digital }\end{array}$ & Non-digital & Online & Online \\
\hline 1674 & Offline & Offline & Blended & Brain $+d+n-d$ & $\begin{array}{l}\text { Non- } \\
\text { digital }\end{array}$ & Non-digital & Online & Offline \\
\hline 1675 & Offline & Offline & Blended & Brain $+d+n-d$ & $\begin{array}{l}\text { Non- } \\
\text { digital }\end{array}$ & Non-digital & Offline & Online \\
\hline 1676 & Offline & Offline & Blended & Brain $+d+n-d$ & $\begin{array}{l}\text { Non- } \\
\text { digital }\end{array}$ & Non-digital & Offline & Offline \\
\hline 1677 & Offline & Offline & Blended & Brain $+d+n-d$ & $\begin{array}{l}\text { Non- } \\
\text { digital }\end{array}$ & Blended & Online & Online \\
\hline 1678 & Offline & Offline & Blended & Brain $+d+n-d$ & $\begin{array}{l}\text { Non- } \\
\text { digital }\end{array}$ & Blended & Online & Offline \\
\hline 1679 & Offline & Offline & Blended & Brain $+d+n-d$ & $\begin{array}{l}\text { Non- } \\
\text { digital }\end{array}$ & Blended & Offline & Online \\
\hline 1680 & Offline & Offline & Blended & Brain $+d+n-d$ & $\begin{array}{l}\text { Non- } \\
\text { digital }\end{array}$ & Blended & Offline & Offline \\
\hline 1681 & Offline & Offline & Blended & Brain $+d+n-d$ & $\begin{array}{l}\text { Blend- } \\
\text { ed }\end{array}$ & Digital & Online & Online \\
\hline 1682 & Offline & Offline & Blended & Brain $+d+n-d$ & $\begin{array}{l}\text { Blend- } \\
\text { ed }\end{array}$ & Digital & Online & Offline \\
\hline 1683 & Offline & Offline & Blended & Brain $+d+n-d$ & $\begin{array}{l}\text { Blend- } \\
\text { ed }\end{array}$ & Digital & Offline & Online \\
\hline 1684 & Offline & Offline & Blended & Brain $+d+n-d$ & $\begin{array}{l}\text { Blend- } \\
\text { ed }\end{array}$ & Digital & Offline & Offline \\
\hline 1685 & Offline & Offline & Blended & Brain $+d+n-d$ & $\begin{array}{l}\text { Blend- } \\
\text { ed }\end{array}$ & Non-digital & Online & Online \\
\hline 1686 & Offline & Offline & Blended & Brain $+d+n-d$ & $\begin{array}{l}\text { Blend- } \\
\text { ed }\end{array}$ & Non-digital & Online & Offline \\
\hline 1687 & Offline & Offline & Blended & Brain $+d+n-d$ & $\begin{array}{l}\text { Blend- } \\
\text { ed }\end{array}$ & Non-digital & Offline & Online \\
\hline 1688 & Offline & Offline & Blended & Brain $+d+n-d$ & $\begin{array}{l}\text { Blend- } \\
\text { ed }\end{array}$ & Non-digital & Offline & Offline \\
\hline 1689 & Offline & Offline & Blended & Brain $+d+n-d$ & $\begin{array}{l}\text { Blend- } \\
\text { ed }\end{array}$ & Blended & Online & Online \\
\hline 1690 & Offline & Offline & Blended & Brain $+d+n-d$ & $\begin{array}{l}\text { Blend- } \\
\text { ed }\end{array}$ & Blended & Online & Offline \\
\hline 1691 & Offline & Offline & Blended & Brain $+d+n-d$ & $\begin{array}{l}\text { Blend- } \\
\text { ed }\end{array}$ & Blended & Offline & Online \\
\hline 1692 & Offline & Offline & Blended & Brain $+d+n-d$ & $\begin{array}{l}\text { Blend- } \\
\text { ed }\end{array}$ & Blended & Offline & Offline \\
\hline 1693 & Offline & Offline & Blended & Brain $+n-d$ & Digital & Digital & Online & Online \\
\hline
\end{tabular}




\begin{tabular}{|c|c|c|c|c|c|c|c|c|}
\hline 1694 & Offline & Offline & Blended & Brain $+n-d$ & Digital & Digital & Online & Offline \\
\hline 1695 & Offline & Offline & Blended & Brain $+n-d$ & Digital & Digital & Offline & Online \\
\hline 1696 & Offline & Offline & Blended & Brain $+n-d$ & Digital & Digital & Offline & Offline \\
\hline 1697 & Offline & Offline & Blended & Brain $+n-d$ & Digital & Non-digital & Online & Online \\
\hline 1698 & Offline & Offline & Blended & Brain $+n-d$ & Digital & Non-digital & Online & Offline \\
\hline 1699 & Offline & Offline & Blended & Brain $+n-d$ & Digital & Non-digital & Offline & Online \\
\hline 1700 & Offline & Offline & Blended & Brain $+n-d$ & Digital & Non-digital & Offline & Offline \\
\hline 1701 & Offline & Offline & Blended & Brain + n-d & Digital & Blended & Online & Online \\
\hline 1702 & Offline & Offline & Blended & Brain $+n-d$ & Digital & Blended & Online & Offline \\
\hline 1703 & Offline & Offline & Blended & Brain $+n-d$ & Digital & Blended & Offline & Online \\
\hline 1704 & Offline & Offline & Blended & Brain $+n-d$ & Digital & Blended & Offline & Offline \\
\hline 1705 & Offline & Offline & Blended & Brain + n-d & $\begin{array}{l}\text { Non- } \\
\text { digital }\end{array}$ & Digital & Online & Online \\
\hline 1706 & Offline & Offline & Blended & Brain $+n-d$ & $\begin{array}{l}\text { Non- } \\
\text { digital }\end{array}$ & Digital & Online & Offline \\
\hline 1707 & Offline & Offline & Blended & Brain $+n-d$ & $\begin{array}{l}\text { Non- } \\
\text { digital }\end{array}$ & Digital & Offline & Online \\
\hline 1708 & Offline & Offline & Blended & Brain $+n-d$ & $\begin{array}{l}\text { Non- } \\
\text { digital }\end{array}$ & Digital & Offline & Offline \\
\hline 1709 & Offline & Offline & Blended & Brain + n-d & $\begin{array}{l}\text { Non- } \\
\text { digital }\end{array}$ & Non-digital & Online & Online \\
\hline 1710 & Offline & Offline & Blended & Brain + n-d & $\begin{array}{l}\text { Non- } \\
\text { digital }\end{array}$ & Non-digital & Online & Offline \\
\hline 1711 & Offline & Offline & Blended & Brain + n-d & $\begin{array}{l}\text { Non- } \\
\text { digital }\end{array}$ & Non-digital & Offline & Online \\
\hline 1712 & Offline & Offline & Blended & Brain + n-d & $\begin{array}{l}\text { Non- } \\
\text { digital }\end{array}$ & Non-digital & Offline & Offline \\
\hline 1713 & Offline & Offline & Blended & Brain + n-d & $\begin{array}{l}\text { Non- } \\
\text { digital }\end{array}$ & Blended & Online & Online \\
\hline 1714 & Offline & Offline & Blended & Brain + n-d & $\begin{array}{l}\text { Non- } \\
\text { digital }\end{array}$ & Blended & Online & Offline \\
\hline 1715 & Offline & Offline & Blended & Brain $+n-d$ & $\begin{array}{l}\text { Non- } \\
\text { digital }\end{array}$ & Blended & Offline & Online \\
\hline 1716 & Offline & Offline & Blended & Brain $+n-d$ & $\begin{array}{l}\text { Non- } \\
\text { digital }\end{array}$ & Blended & Offline & Offline \\
\hline 1717 & Offline & Offline & Blended & Brain $+n-d$ & $\begin{array}{l}\text { Blend- } \\
\text { ed }\end{array}$ & Digital & Online & Online \\
\hline 1718 & Offline & Offline & Blended & Brain $+n-d$ & $\begin{array}{l}\text { Blend- } \\
\text { ed }\end{array}$ & Digital & Online & Offline \\
\hline 1719 & Offline & Offline & Blended & Brain + n-d & $\begin{array}{l}\text { Blend- } \\
\text { ed }\end{array}$ & Digital & Offline & Online \\
\hline 1720 & Offline & Offline & Blended & Brain $+n-d$ & $\begin{array}{l}\text { Blend- } \\
\text { ed }\end{array}$ & Digital & Offline & Offline \\
\hline 1721 & Offline & Offline & Blended & Brain + n-d & $\begin{array}{l}\text { Blend- } \\
\text { ed }\end{array}$ & Non-digital & Online & Online \\
\hline 1722 & Offline & Offline & Blended & Brain $+n-d$ & $\begin{array}{l}\text { Blend- } \\
\text { ed }\end{array}$ & Non-digital & Online & Offline \\
\hline 1723 & Offline & Offline & Blended & Brain + n-d & $\begin{array}{l}\text { Blend- } \\
\text { ed }\end{array}$ & Non-digital & Offline & Online \\
\hline 1724 & Offline & Offline & Blended & Brain + n-d & $\begin{array}{l}\text { Blend- } \\
\text { ed }\end{array}$ & Non-digital & Offline & Offline \\
\hline 1725 & Offline & Offline & Blended & Brain $+n-d$ & $\begin{array}{l}\text { Blend- } \\
\text { ed }\end{array}$ & Blended & Online & Online \\
\hline 1726 & Offline & Offline & Blended & Brain + n-d & $\begin{array}{l}\text { Blend- } \\
\text { ed }\end{array}$ & Blended & Online & Offline \\
\hline 1727 & Offline & Offline & Blended & Brain $+n-d$ & $\begin{array}{l}\text { Blend- } \\
\text { ed }\end{array}$ & Blended & Offline & Online \\
\hline 1728 & Offline & Offline & Blended & Brain + n-d & $\begin{array}{l}\text { Blend- } \\
\text { ed }\end{array}$ & Blended & Offline & Offline \\
\hline
\end{tabular}

